\title{
Change in dense forest habitat for endangered wildlife species in Costa Rica from 1940 to 1977
}

\author{
Christopher Vaughan \\ International Institute for Wildlife Conservation and Management, Universidad Nacional, Heredia, Costa Rica. \\ Department of Forest and Wildlife Ecology, University of Wisconsin, Madison, WI 53706; cvaughan@wisc.edu \\ Associated Colleges of the Midwest, San Jose, Costa Rica; cvaughan@acm.edu
}

Recibido 15-XI-2010 Corregido 10-XII-2010 Aceptado 21-I-2011

\begin{abstract}
Habitat availability is a key factor in biological extinctions. Existence and loss of dense forest habitat for 27 endangered wildlife species in Costa Rica is quantified and analyzed using vegetation maps, density estimates and insular ecology theory. From 1940 to 1977 species suffered an average $35 \%$ destruction of dense forest habitat. A number of species including: Myrmecophaga tridactyla, Panthera onca, Harpia harpyja and Ara ambigua will probably go extinct in Costa Rica within the next century due to lack of sufficiently large dense forest habitat areas for survival. The importance of protecting large areas of dense forest habitat for conserving genetically "viable" wildlife populations is emphasized and key areas are identified for each species. In addition species are ranked as to degree of endangerment using biological parameters.
\end{abstract}

\section{KEY WORDS}

Endangered species, dense forest, viable populations, protected areas.

\section{RESUMEN}

El hábitat es un elemento clave en la extinción de especies. Con base en mapas de vegetación, estimaciones de densidad poblacional y teoría de ecología insular analizo la pérdida de bosque denso para 27 especies de Costa Rica. Entre 1940 y 1977, sufrieron en promedio 35\% de destrucción del hábitat de bosque denso. Especies como Myrmecophaga tridactyla, Panthera onca, Harpia harpyja y Ara ambigua probablemente se van a extinguir en Costa Rica dentro del próximo siglo debido a que les hace falta suficientes áreas de bosque denso para sobrevivir. Es fundamental la importancia de proteger áreas grandes de hábitat de bosque denso para conservar poblaciones "viables" de vida silvestre.

\section{PALABRAS CLAVE}

Especies en vías de extinción, bosque denso, poblaciones viables, áreas silvestres.
Of a total of 674 vertebrate species currently (1983) considered endangered with extinction on a worldwide level, 449 (67\%) are in this state primarily because of habitat destruction, the most serious threat to all vertebrate groups except for certain reptiles (IUCN 1976, 1978). In tropical countries, it is estimated that 10-20 million hectares of forest cover is decreasing per year and if this trend continues, $50 \%$ of existing tropical forests will be eliminated in the next 20 years. The principal direct causes of forest loss are: (a) poorly managed industrial logging, (b) fuel wood gathering, and (c) its conversion and use for agriculture and cattle raising (US Dept. of State 1981). Latin America contains about five million $\mathrm{km}^{2}$ or over $50 \%$ of the worlds remaining tropical moist forests, with about 4,7 million $\mathrm{km}^{2}$ found in South America and the rest in Central America and the Caribbean (Myers 1980). In Latin America, most countries have long endangered species lists and the major threat to these animals is considered to be habitat alteration (Fosberg 1973). Unfortunately information on tropical forest destruction (Myers 1980, Whitmore 1980 ) is usually general in nature and does not quantify species status (Vaughan 1978).

Recent information in insular ecology theory suggests great importance in the distribution and size of primary vegetation islands or isolates for conservation of genetically viable populations of vertebrate wildlife (Terborgh 1974, Diamond 1975, Pickett \& Thompson 1978, Wilcox 1980, Frankel \& Soulé 1981). 
The objective of this study is to provide data on the recent historic and present size and distribution of dense forest habitat in Costa Rica for 27 vertebrate wildlife species, most of which are legally protected and recognized as endangered in Costa Rica. The results clarify: (a) general habitat requirements for each species, (b) the current status of endangered species, (c) the current status of endangered species in Costa Rica as relates to dense forest ( $80-100 \%$ forest cover) habitat destruction with emphasis in the last 40 years, (d) location of protected and unprotected dense forest habitat for each species and, e) the feasibility of conserving "viable" populations of these species in Costa Rica and elsewhere for long-term fitness defined as the minimum effective population size that provides for continuing evolutionary change in quantitative characters (Frankel \& Soulé 1981).

\section{METHODOLOGY}

Most of the wildlife species discussed here are protected by Costa Rica law as endangered species (Poder Ejecutivo 1979). Identification and calculation of dense forest habitat for each wildlife species follows that suggested by Vaughan (1978) and is summarized below. First, a literature review and interviews with knowledgeable persons determined recent historic distribution, densities and habitat types for each species in Costa Rica and throughout its range. Second, trained university students using photographs of each species to aid in identification interviewed hunters and scientist throughout Costa Rica (Fig. 2 in Appendix 5) and located recent sightings (1975-1979) of endangered species on topographical maps (1:200.000 scale). A maximum of three observations for species was recorded from each person interviewed. Observations were plotted on individual maps (1:1.000.000 scale) for each species. Third, distribution of dense forest habitat (80-100\% forest cover) for different years (Preconquest (1500), 1940, 1950, 1961, 1977) was mapped for each species using altitudinal and geographical limitations, interview data mentioned above and dense forest vegetation maps for those periods (Dirección General Forestal 1979). For each species, a second map for 1977 forest cover map was divided into the following vegetative habitats: (a) $90-100 \%$ forest cover, (b) $45-80 \%$ forest cover and (c) swamp forest, mangrove and subalpine paramo. Species observations (1975-1979) were also plotted on individual maps. Fourth, size of dense habitats for different years, vegetation types in 1977 and protected and unprotected island or isolates of dense forest habitat in 1977 were calculated by electronic planimeter (Hewlett-Packer 9862-X-Y Plotter).
Finally, the number of individuals for each wildlife species in dense forest habitat islands in 1977 was also estimated by multiplying those areas by densities reported in the literature for each species. Literature review (Goodwin 1946, Handley 1950, Hall \& Kelson 1959, Skutch 1964, Slud 1964, Leopold, 1965, Henderson 1969, Hornocker 1969, Land 1970, Peterson \& Chalif 1973, Mendez 1974, Ridgeley 1976) and interviews were carried out.

\section{ANALYSIS}

Eight of the 27 wildlife species studied were found in dense forest habitat country wide from sea level to about $3000 \mathrm{~m}$ including subalpine paramo. Sixteen species were present in dense forest habitats at different elevations countrywide. The squirrel monkey, green macaw and the manatee occur in part of the Atlantic or Pacific slope. The crocodilians were grouped because of the difficulty in mapping habitat differences between them (Table 1).

This section will focus on the following points: (a) destruction of dense forest habitat up to 1977, (b) dense forest habitat in 1977, (c) altered areas and wilderness, (d) islands or isolates of dense forest habitat in 1977, (e) minimum population size for long-term species fitness, (f) the problem of calculating species densities in the tropics, (g) protected and unprotected dense forest habitat, (h) summary of important data for each species and (i) ranking of endangered wildlife species.

\section{Destruction of dense forest habitat up to 1977}

Before the Spanish Conquest, dense forest covered an estimated $49000 \mathrm{~km}^{2}(96 \%)$ of Costa Rica with about $2000 \mathrm{~km}^{2}$ (4\%) made up of mangrove, swamp forest and subalpine paramo. The extension of clearing made by indigenous tribes is unknown. Up to 1940 , only about $15000 \mathrm{~km}^{2}$ (31\%) of the dense forest habitat had been altered (Table 2) and this alteration was concentrated in northwestern and central Costa Rica. Only 37 years later (1940-1977), 18000km² (38\%) of the dense forest habitat was deforested, mostly on the Atlantic and South Pacific regions (Oficina de Planificación del Sector Agropecuario 1979).

Habitat of six widely distributed wildlife species, including the jaguar and tapir, follow the same pattern of dense forest destruction as that outlined in Table 2. Others, including the quetzal and squirrel monkey, have a more restricted distribution and occupied $25 \%$ and $15 \%$ respectively of the original dense forest habitat of wildlife species mentioned above. The squirrel monkey and giant anteater are found in lowland tropical forest habitats which have been under intense deforestation pressure since 1940, 


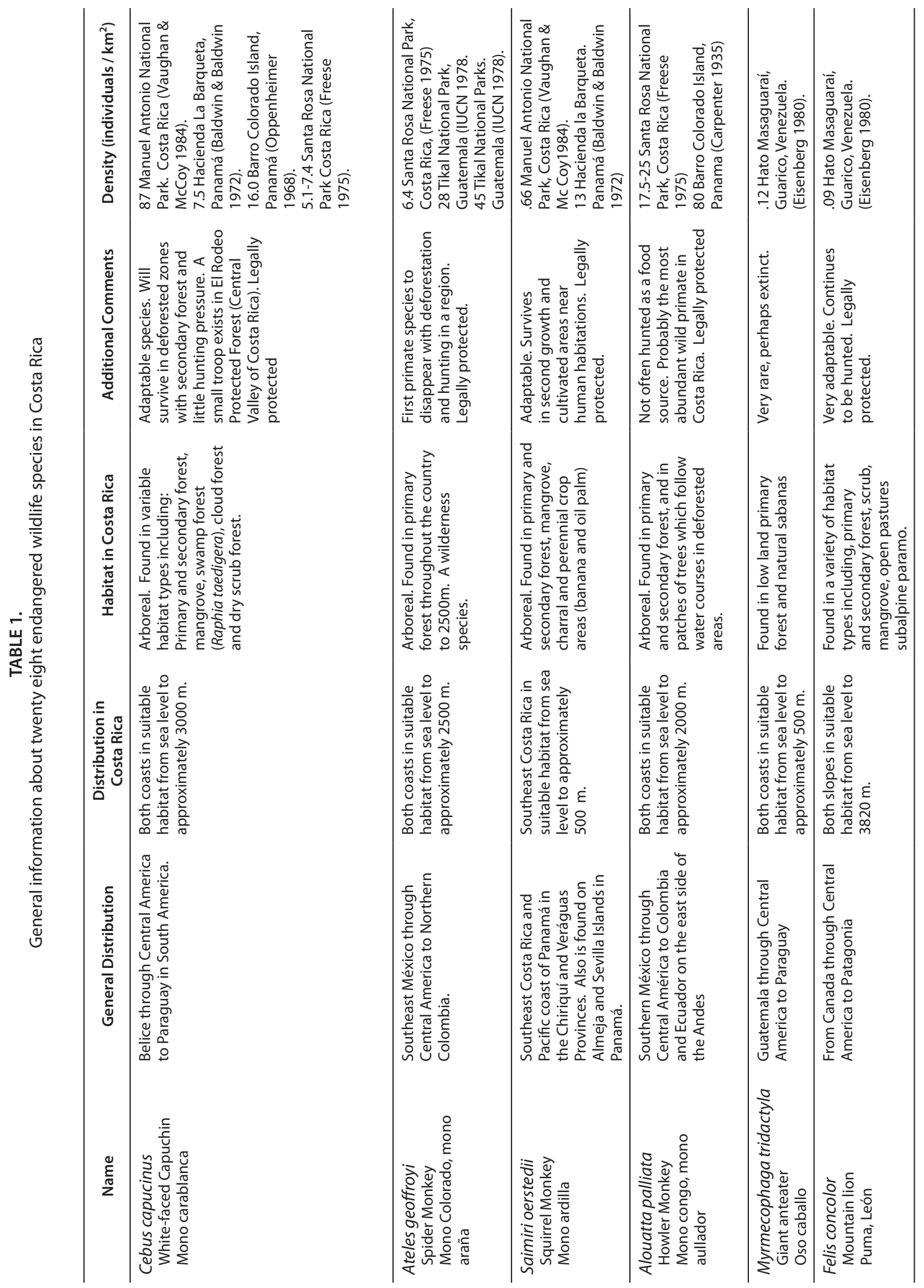




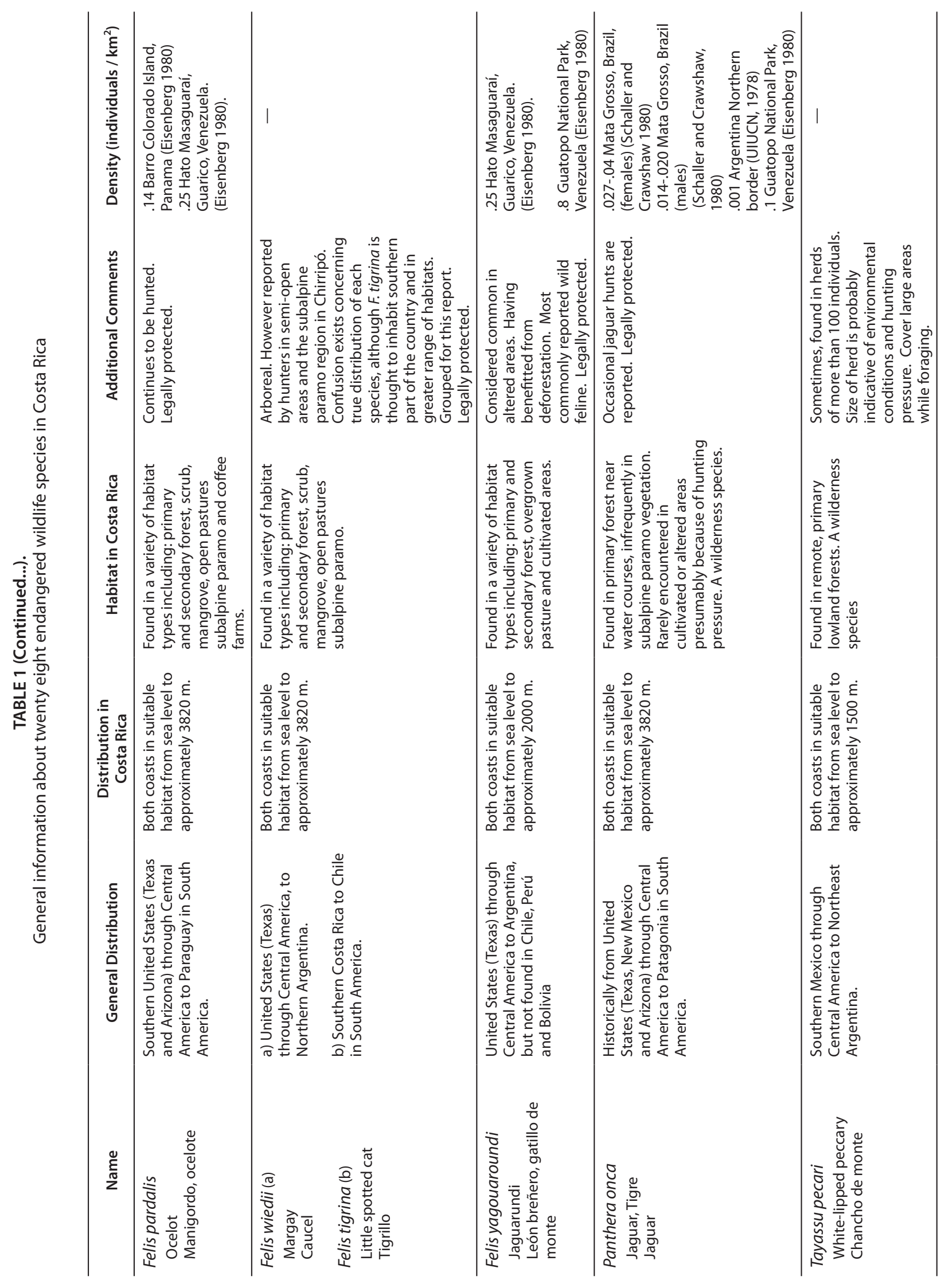




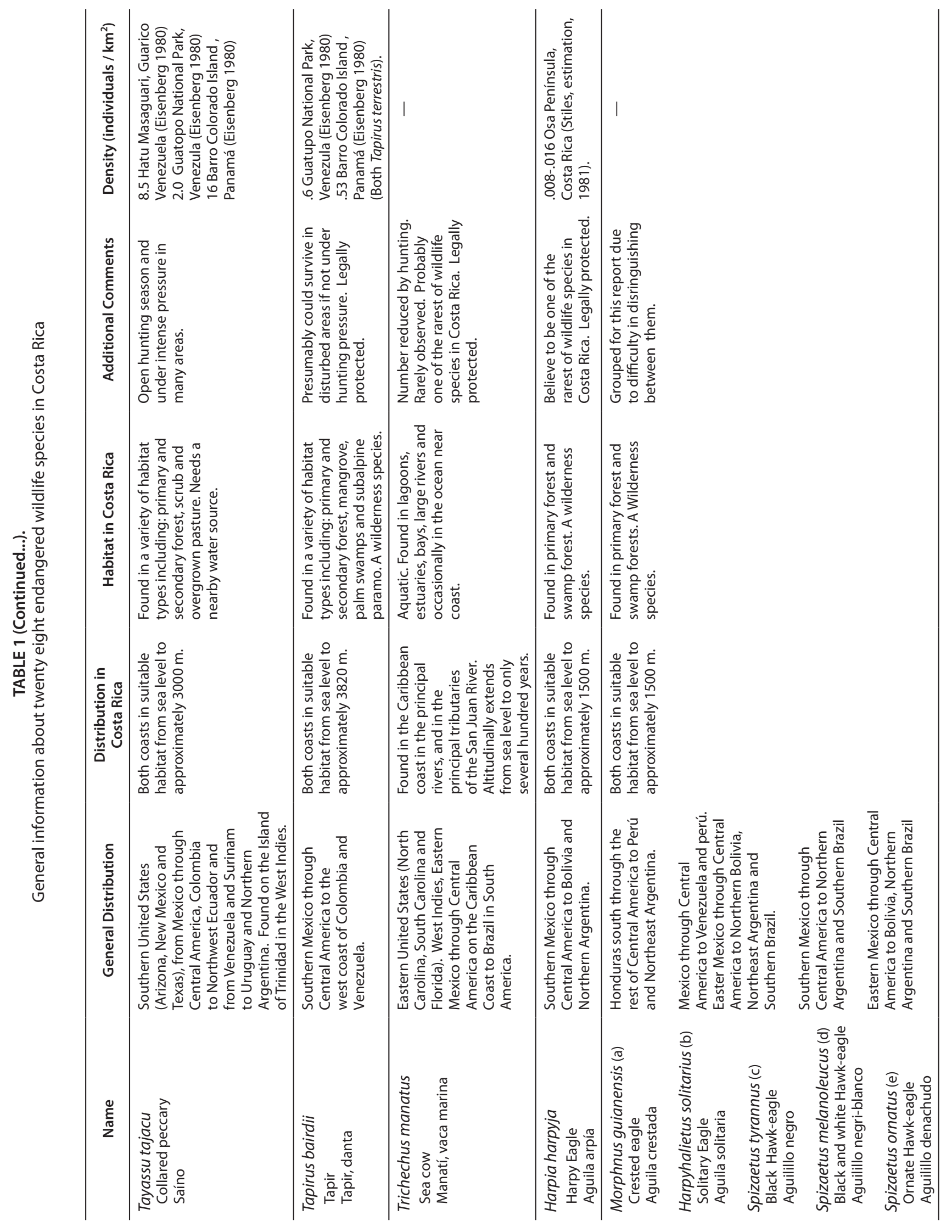




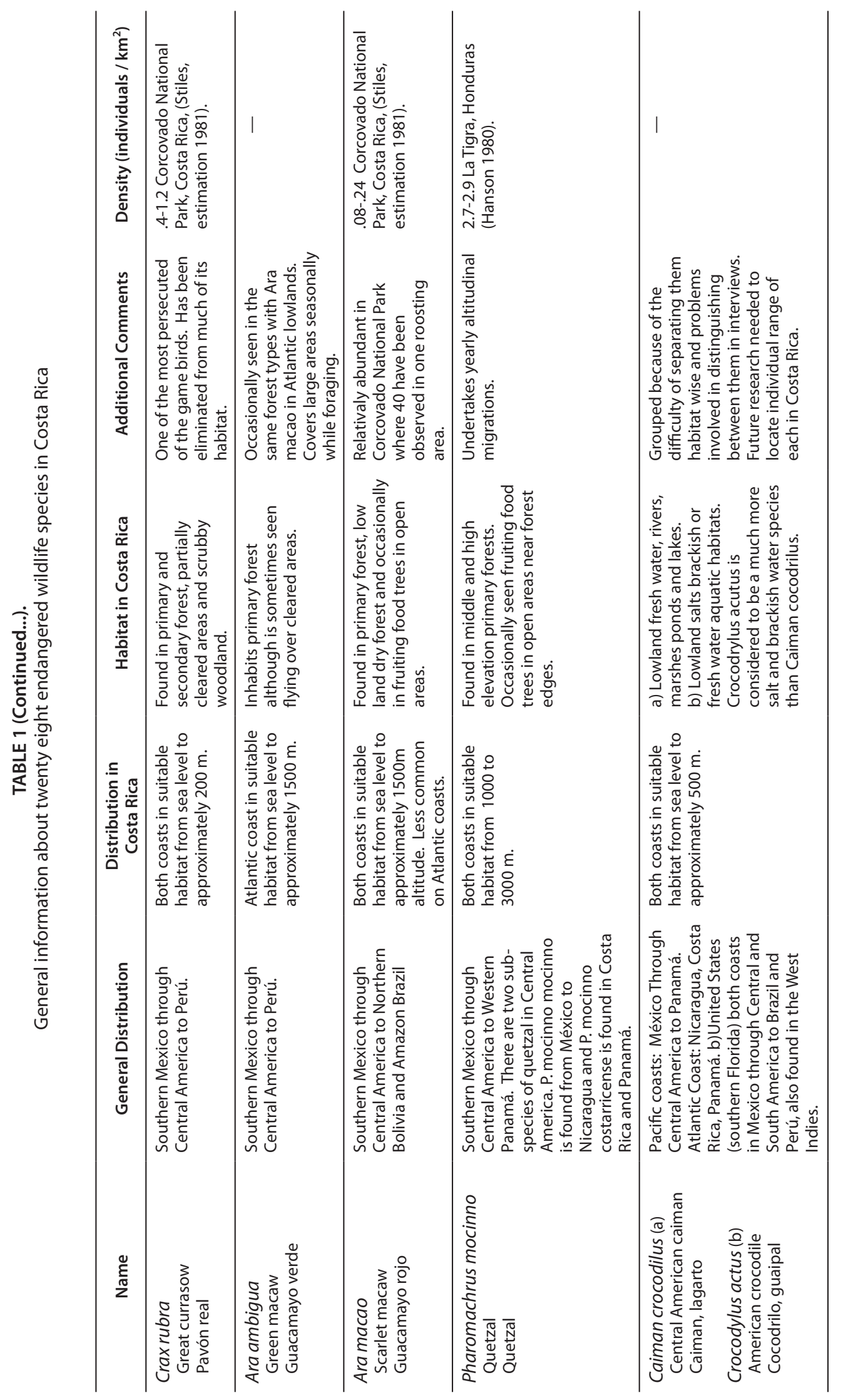


TABLE 2

Extension of dense forest in Costa Rica up to 1977

$\begin{array}{lcc}\text { Year } & \begin{array}{c}\text { Dense forest }\left(^{*}\right) \\ \mathrm{Km}^{2}\end{array} & \begin{array}{c}\mathbf{8 0 - 1 0 0 \%} \\ \text { forest cover (\%) }\end{array} \\ \text { Preconquest, (1500) } & 4884\left(^{* *}\right) & 100 \\ 1940 & 33538\left(^{* *}\right) & 69 \\ 1950 & 27084 & 53 \\ 1961 & 23122 & 45 \\ 1977 & 15901 & 31 \\ \text { (*) Does not include mangrove and swamp forest. }^{* *} \text { Rough estimations. } \\ \text { Source: Oficina de Planificación del Sector Agropecuario, } 1979 .\end{array}$

losing $45 \%$ and $39 \%$ of dense forest habitat respectively. In contrast, the quetzal, found between $1000-3000 \mathrm{~m}$ elevation lost only $19 \%$ of its dense forest habitat between 1940 and 1977. On average, the wildlife species studied had their dense forest habitat reduced by $35 \%$ between 1940-1977 with extremes of $19 \%$ and $45 \%$. Between the Spanish Conquest and 1940, these same species had their dense forest habitat reduced by an average of 32\% with extremes of $13 \%$ and $37 \%$ (Fig. 3-10). Thus, many species lost as much or more dense forest habitat from 1940 to 1977 as they did in the 400 years prior to 1940 .

\section{Dense forest habitat in 1977}

In 1977, there was about $15901 \mathrm{~km}^{2}$ of dense forest in Costa Rica or about $31 \%$ of original forest cover. This was concentrated in the following regions: (a) Talamanca Mountain Range $\left(7900 \mathrm{~km}^{2}\right)$ from sea level to about 3000m elevation; (b) north slopes of Barva, Irazú and Turrialba Volcanoes $\left(1406 \mathrm{~km}^{2}\right)$ from 300 to $3000 \mathrm{~m}$ levitation, (c) the lowland forested regions of Chambacú $\left(2741 \mathrm{~km}^{2}\right)$, and d) the Osa Península $\left(1246 \mathrm{~km}^{2}\right)$ both from about sea level to several hundred meters elevation. The amount of dense forest habitat for a species within any of these areas depends on the altitudinal and geographical distribution for that species. In 1977, the species studied had an average of about $28-30 \%$ of their original dense forest habitat (Table 3). The squirrel monkey with 30\% (2143 $\left.\mathrm{km}^{2}\right)$ of its original forest habitat, the giant anteater with $24 \%$ $\left(7315 \mathrm{~km}^{2}\right)$ and the quetzal with $60 \%\left(6730 \mathrm{~km}^{2}\right)$ represented the extremes (Fig. 11-31).

Including the $45-80 \%$ forest cover, total forest area increases dramatically (Table 3). This category of forest land contains much edge and mixed stages of habitat types, favorable for a number of species and the negative factor of human inhabitants.

\section{Altered areas and wilderness}

By studying the distribution of observations for each species (Fig. 11-31), one concludes that 16 wilderness species were found almost exclusively in dense forest regions and 11 species were found in both dense forest and disturbed areas (Tables 1 and 3). A species could be found in both altered and dense forested areas for numerous and non-exclusive reasons such as: a) the altered areas alone or in combination with the dense forest area meet minimum habitat requirements, b) hunting pressure is not great, and c) the species possesses an effective escape mechanism from man in altered areas just as in dense forest habitats.

Perhaps many, if not all, species in this report could subsist in altered areas if not for hunting pressure. For instance, the tapir and jaguar occur in the forest pasture mixture in Santa Rosa National Park. If not under hunting pressure, species adapted to live or at least migrate through habitat types other than dense forest (Foster 1980) could prevent their local or national extinction. A continuous distribution in a region even with density differences between habitats would assure some exchange of genetic information within the species.

\section{Islands or isolates of dense forest habitat in 1977}

Knowledge of total dense forest available in a country and throughout its range is important for each wildlife species. However, size and distribution of dense forest habitat islands determines population size with a minimum population needed in an area for long term survival.

According to insular ecology theory, habitat fragmentation can be dissected into two components: habitat loss and insularization. Habitat loss excludes a portion of a faunal type, particularly rare species because of reduced population size. Habitat insularization extinguishes "protected" species within an area by removing required resources outside the area and reduces accessibility for and sources of colonists (Wilcox 1980). In quantitative terms, it is calculated that each tenfold decrease in area could result in a $30 \%$ exclusion or regional fauna as described by the species-areas curve (MacArthur \& Wilson 1967). Table 4 presents a list of the largest protected and unprotected islands of dense forest vegetation in Costa Rica in 1977 for each species. Appendices 1, 2 and 3 show approximate size of dense forest habitat for each species within protected wildlands in 1977. 
TABLE 3

Size of forest habitat of endangered wildlife species in Costa Rica (1940-1977)

\begin{tabular}{|c|c|c|c|c|c|c|c|c|}
\hline \multirow[t]{2}{*}{ Species } & \multirow{2}{*}{$\begin{array}{l}\text { Altitudinal } \\
\text { range }(m)\end{array}$} & \multicolumn{5}{|c|}{$\begin{array}{c}\text { Dense forest }(80-100 \% \text { cover })\left(\mathrm{km}^{2}\right) \\
\%\end{array}$} & \multirow{2}{*}{$\begin{array}{c}\text { Forest } \\
45-80 \% \text { cover }) \\
\left(\mathrm{km}^{2}\right)(1977)\end{array}$} & \multirow{2}{*}{$\begin{array}{c}\text { Mangrove, } \\
\text { swamp-fores } \\
\left(\mathrm{km}^{2}\right)(1977)\end{array}$} \\
\hline & & Preconquest & 1940 & 1950 & 1961 & 1977 & & \\
\hline Cebus capucinus $^{(1)}$ & $0-3000$ & $\begin{array}{l}48845 \\
(100 \%)\end{array}$ & $\begin{array}{c}33538 \\
69 \%\end{array}$ & $\begin{array}{c}27084 \\
55 \%\end{array}$ & $\begin{array}{c}23122 \\
47 \%\end{array}$ & $\begin{array}{c}15901 \\
33 \%\end{array}$ & 7882 & 1979 \\
\hline Ateles geoffroyi & $0-2500$ & $\begin{array}{l}47783 \\
(100 \%)\end{array}$ & $\begin{array}{c}32476 \\
68 \%\end{array}$ & $\begin{array}{c}26022 \\
55 \%\end{array}$ & $\begin{array}{c}22060 \\
46 \%\end{array}$ & $\begin{array}{c}14839 \\
31 \%\end{array}$ & 7882 & - \\
\hline Saimiri oerstedii ${ }^{(1)}$ & $\begin{array}{c}0-500 \\
\text { Southern } \\
\text { Pacific }\end{array}$ & $\begin{array}{c}7255 \\
(100 \%)\end{array}$ & $\begin{array}{l}5434 \\
75 \%\end{array}$ & $\begin{array}{l}4435 \\
61 \%\end{array}$ & $\begin{array}{l}3400 \\
47 \%\end{array}$ & $\begin{array}{l}2143 \\
30 \%\end{array}$ & 1278 & - \\
\hline Alouatta palliata ${ }^{(1)}$ & $0-2000$ & $\begin{array}{l}46188 \\
(100 \%)\end{array}$ & $\begin{array}{c}29378 \\
64 \%\end{array}$ & $\begin{array}{c}24352 \\
53 \%\end{array}$ & $\begin{array}{c}20545 \\
45 \%\end{array}$ & $\begin{array}{c}14507 \\
31 \%\end{array}$ & 7882 & 1979 \\
\hline $\begin{array}{l}\text { Myrmecophaga } \\
\text { tridactyla }\end{array}$ & $0-500$ & $\begin{array}{l}30000 \\
(100 \%)\end{array}$ & $\begin{array}{c}18738 \\
63 \%\end{array}$ & $\begin{array}{c}15304 \\
51 \%\end{array}$ & $\begin{array}{c}12400 \\
41 \%\end{array}$ & $\begin{array}{l}7315 \\
24 \%\end{array}$ & 5661 & 1979 \\
\hline Felis concolor ${ }^{(1,2)}$ & $0-3820$ & $\begin{array}{l}48845 \\
(100 \%)\end{array}$ & $\begin{array}{c}33538 \\
67 \%\end{array}$ & $\begin{array}{c}27084 \\
55 \%\end{array}$ & $\begin{array}{c}23122 \\
47 \%\end{array}$ & $\begin{array}{c}15901 \\
33 \%\end{array}$ & 7882 & 1979 \\
\hline Felis pardalis ${ }^{(1,2)}$ & $0-3820$ & $\begin{array}{l}48845 \\
(100 \%)\end{array}$ & $\begin{array}{c}33538 \\
67 \%\end{array}$ & $\begin{array}{c}27084 \\
55 \%\end{array}$ & $\begin{array}{c}23122 \\
47 \%\end{array}$ & $\begin{array}{c}15901 \\
33 \%\end{array}$ & 7882 & 1979 \\
\hline $\begin{array}{l}\text { Felis wiedii }^{(1,2)} \\
\text { Felis tigrina }\end{array}$ & $0-3820$ & $\begin{array}{l}48845 \\
(100 \%)\end{array}$ & $\begin{array}{c}33538 \\
67 \%\end{array}$ & $\begin{array}{c}27084 \\
55 \%\end{array}$ & $\begin{array}{c}23122 \\
47 \%\end{array}$ & $\begin{array}{c}15901 \\
33 \%\end{array}$ & 7882 & 1979 \\
\hline Felis yagouaroundi ${ }^{(1)}$ & $0-2000$ & $\begin{array}{l}46188 \\
(100 \%)\end{array}$ & $\begin{array}{c}29378 \\
64 \%\end{array}$ & $\begin{array}{c}24352 \\
53 \%\end{array}$ & $\begin{array}{c}20645 \\
45 \%\end{array}$ & $\begin{array}{c}14507 \\
31 \%\end{array}$ & 7882 & 1979 \\
\hline Panthera onca ${ }^{(2)}$ & $0-3820$ & $\begin{array}{l}48845 \\
(100 \%)\end{array}$ & $\begin{array}{c}33538 \\
67 \%\end{array}$ & $\begin{array}{c}27084 \\
55 \%\end{array}$ & $\begin{array}{c}23122 \\
47 \%\end{array}$ & $\begin{array}{c}15901 \\
33 \%\end{array}$ & 7882 & 1979 \\
\hline Tayassau pecari & $0-1500$ & $\begin{array}{l}42501 \\
(100 \%) \\
\end{array}$ & $\begin{array}{c}28131 \\
66 \%\end{array}$ & $\begin{array}{c}23231 \\
55 \%\end{array}$ & $\begin{array}{c}18298 \\
43 \%\end{array}$ & $\begin{array}{c}12422 \\
29 \%\end{array}$ & 7409 & 1979 \\
\hline Tayassau tajacu $u^{(1)}$ & $0-3000$ & $\begin{array}{l}48845 \\
(100 \%)\end{array}$ & $\begin{array}{c}33538 \\
67 \%\end{array}$ & $\begin{array}{c}27084 \\
55 \%\end{array}$ & $\begin{array}{c}23122 \\
47 \%\end{array}$ & $\begin{array}{c}15901 \\
33 \%\end{array}$ & 7882 & 1979 \\
\hline Tapirus bairdii( ${ }^{(2)}$ & $0-3820$ & $\begin{array}{l}48845 \\
(100 \%)\end{array}$ & $\begin{array}{c}33538 \\
69 \%\end{array}$ & $\begin{array}{c}27084 \\
55 \%\end{array}$ & $\begin{array}{c}23122 \\
47 \%\end{array}$ & $\begin{array}{c}15903 \\
33 \%\end{array}$ & 7882 & 1979 \\
\hline Trichechus manatus & - & - & 一 & 一 & - & - & - & - \\
\hline Harpia harpyja & $0-1500$ & $\begin{array}{l}42501 \\
(100 \%)\end{array}$ & $\begin{array}{c}28131 \\
66 \%\end{array}$ & $\begin{array}{c}23231 \\
55 \%\end{array}$ & $\begin{array}{c}18298 \\
43 \%\end{array}$ & $\begin{array}{c}12422 \\
29 \%\end{array}$ & 7409 & 1979 \\
\hline $\begin{array}{l}\text { Eagles and } \\
\text { Hawk-eagles }^{(3)}\end{array}$ & $0-1500$ & $\begin{array}{l}42501 \\
(100 \%)\end{array}$ & $\begin{array}{c}28131 \\
66 \%\end{array}$ & $\begin{array}{c}23231 \\
55 \%\end{array}$ & $\begin{array}{c}18298 \\
43 \%\end{array}$ & $\begin{array}{c}12422 \\
29 \%\end{array}$ & 7409 & 1979 \\
\hline Crax rubra $^{(2)}$ & $0-2000$ & $\begin{array}{l}46188 \\
(100 \%)\end{array}$ & $\begin{array}{c}29378 \\
64 \%\end{array}$ & $\begin{array}{c}24352 \\
53 \%\end{array}$ & $\begin{array}{c}20645 \\
45 \%\end{array}$ & $\begin{array}{c}14507 \\
31 \%\end{array}$ & 7409 & 1979 \\
\hline Ara ambigua & $\begin{array}{r}0-1500 \\
\text { Atlantic }\end{array}$ & $\begin{array}{c}18894 \\
(100 \%)\end{array}$ & $\begin{array}{c}16530 \\
87 \%\end{array}$ & $\begin{array}{c}14518 \\
76 \%\end{array}$ & $\begin{array}{c}12658 \\
67 \%\end{array}$ & $\begin{array}{l}8410 \\
45 \%\end{array}$ & - & - \\
\hline Ara macao & $0-1500$ & $\begin{array}{l}42501 \\
(100 \%)\end{array}$ & $\begin{array}{c}28131 \\
66 \%\end{array}$ & $\begin{array}{c}28231 \\
55 \%\end{array}$ & $\begin{array}{c}18298 \\
43 \%\end{array}$ & $\begin{array}{c}12422 \\
29 \%\end{array}$ & 7409 & 1979 \\
\hline Pharomachrus mocinno & $1000-3000$ & $\begin{array}{c}11143 \\
(100 \%)\end{array}$ & $\begin{array}{l}8801 \\
79 \%\end{array}$ & $\begin{array}{l}8266 \\
74 \%\end{array}$ & $\begin{array}{l}7314 \\
66 \%\end{array}$ & $\begin{array}{l}6730 \\
60 \%\end{array}$ & 870 & - \\
\hline Caiman crocodilus $^{(1)}$ & $0-500$ & $\begin{array}{c}30000 \\
(100 \%)\end{array}$ & $\begin{array}{c}18738 \\
63 \%\end{array}$ & $\begin{array}{c}15304 \\
51 \%\end{array}$ & $\begin{array}{c}12400 \\
41 \%\end{array}$ & $\begin{array}{r}7315 \\
24 \%\end{array}$ & 5661 & 1979 \\
\hline Crocodylus acutus & $0-500$ & $\begin{array}{c}30000 \\
(100 \%)\end{array}$ & $\begin{array}{c}18738 \\
63 \%\end{array}$ & $\begin{array}{c}15304 \\
51 \%\end{array}$ & $\begin{array}{c}12400 \\
41 \%\end{array}$ & $\begin{array}{l}7315 \\
24 \%\end{array}$ & 5661 & 1979 \\
\hline
\end{tabular}

(1) Adaptable to alterede environments; (2) Found in subalpino paramo vegetation; (3) Except Harpia harpyja. 


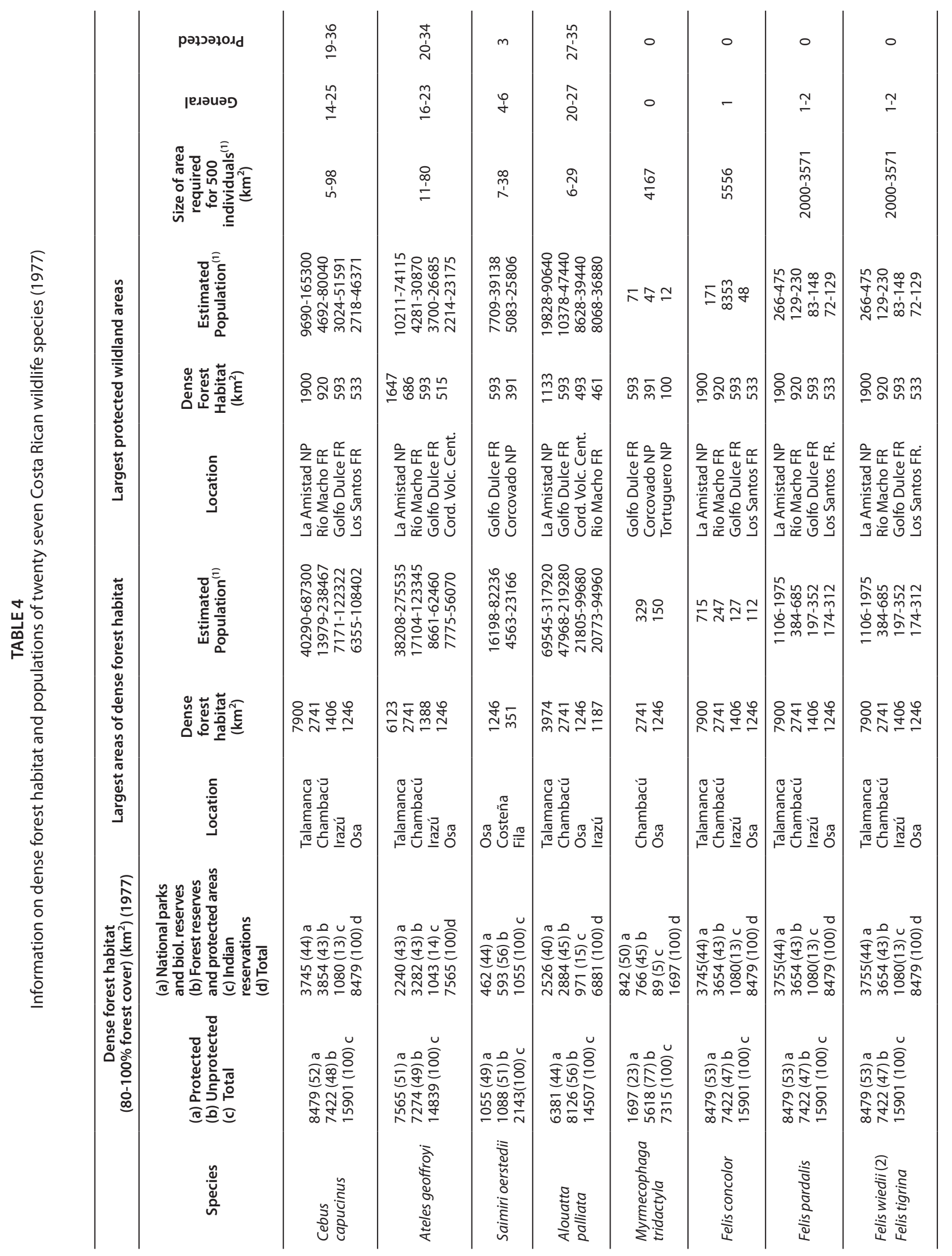




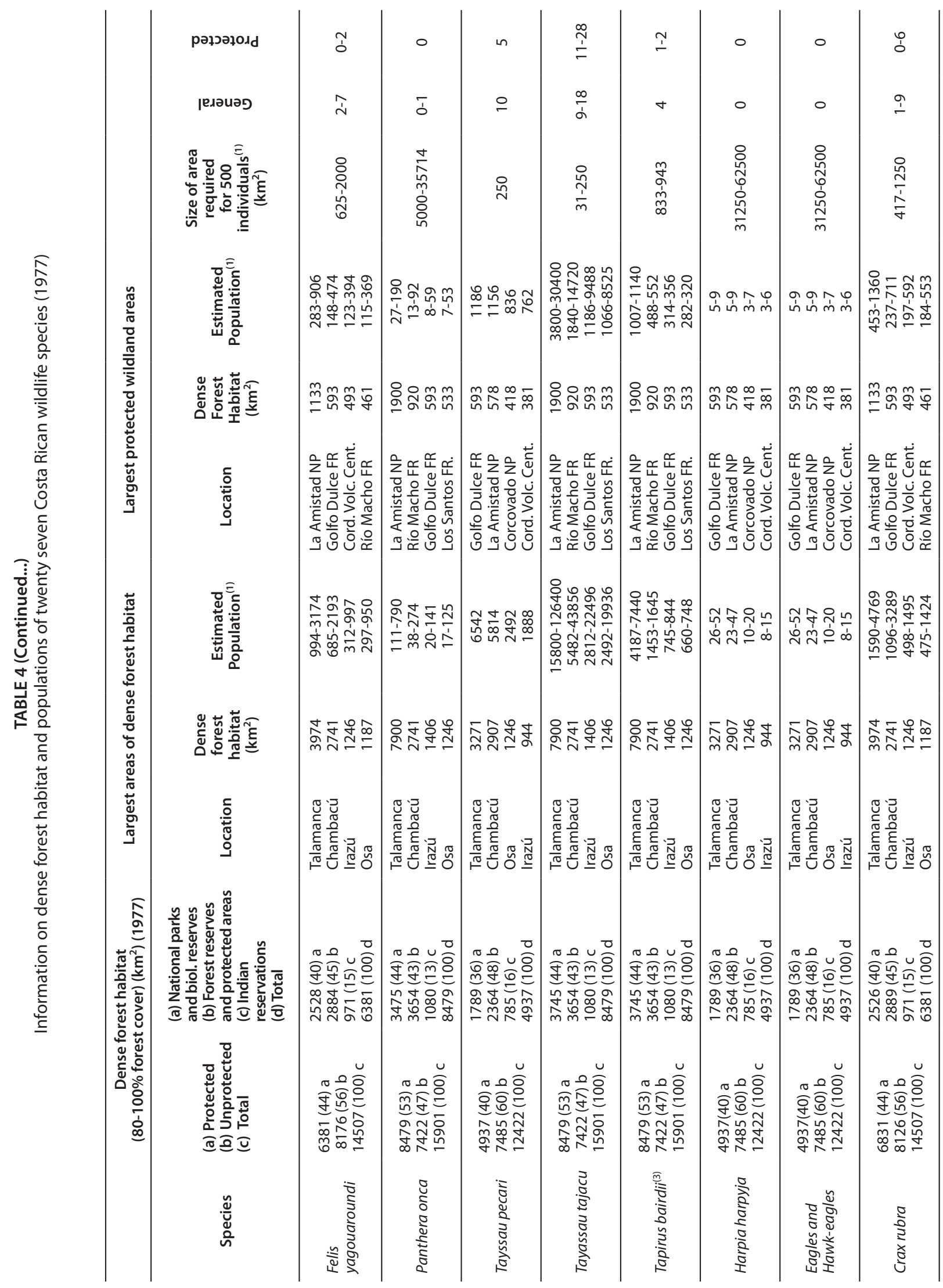




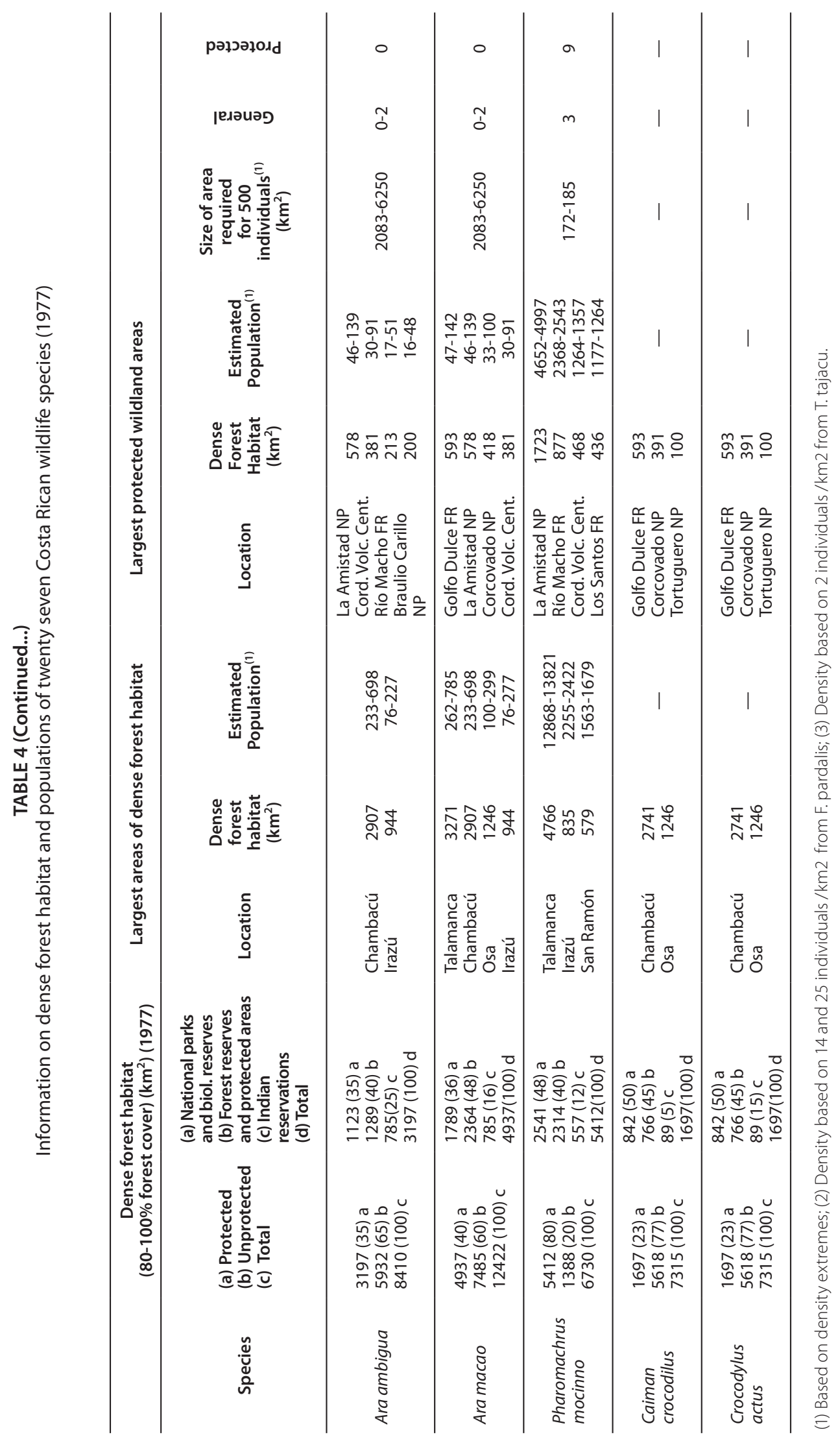




\section{Minimum population size for long-term species fitness}

Most endangered species are susceptible to extinction because habitat loss and insularization lower population sizes below a minimum necessary to maintain an evolutionarily viable population (or long-term fitness) (Frankel \& Soulé 1981). Franklin (1980) using data from Lande (1976) on bristle number variation in Drosophila, proposed a minimum effective population size of 500 as needed for effective genetic variation. He based this number on the fact that: (a) phenotypic traits in conservation biology are quantitative and because the average gene effect is small, most variation is additive, (b) erosion of additive genetic variation does not occur at a significant rate by stabilizing selection, and (c) mutation and genetic drift are important evolutionary forces and a population below some minimum size will lose more variation by drift faster than can be gained by mutation. Frankel \& Soule (1981) arrive at a similar figure by simple genetic theory. It is important to experimentally monitor some species and test this theory. However, implications of this important figure for long term conservation of animal populations within wildland areas are obvious (Frankel \& Soule 1981). The actual number may be several times larger or smaller than this. However for the present report, all discussion and conclusions are based on this figure.

\section{The problem of calculating species densities in the tropics}

Few densities were found in the literature for the wildlife species studied. They are probably unreliable in general because: (a) tropical environments are difficult areas to census species, (b) wildlife species in forested tropical areas are difficult to census because of their habitat, (c) temperate zone sampling techniques are not generally suitable for use in the tropics, (d) few accurate sampling techniques have been developed for tropical species, and (e) interest in estimating densities for tropical species is recent.

Also, densities of wildlife species vary greatly in time and space. The first is a result of the population dynamics of the species. The second factor is influenced by a fluctuating resource base both within and between major vegetation types and successional stages. Eisenberg (1980) showed how Alouatta palliata populations fluctuate widely on Barro Colorado Island due in part to successional stages of vegetation. Johnson \& Vaughan (1993) found small rodent populations highly variable between five habitat types in the Talamanca Mountain Range (Costa Rica) at $2700 \mathrm{~m}$.
I expected that Cebus capucinus could be 10 to 100 times as abundant in a given area of lowland rain forest as an equivalent sized area of high oak forest $(2500 \mathrm{~m}$ elevation) where it is an infrequent visitor. Even within a natural area such a Corcovado National Park with more than 20 recognized vegetation types, differences in population densities of wildlife species may exist between mangrove swamp, dense forest, Raphia swamp forest (Vaughan 1981), or species may indiscriminately use adjoining vegetation types. Stratification of sampling is needed but seldom done (Caughley 1977). For the present report, several species had none or at most one density reported (Table 1) In some cases densities were estimated from the number of individuals in a given area. Other densities were taken from supposedly similar species (Felis pardalisFelis wiedii). No data was available for density differences between habitat types. In many cases densities were given with no explanation of the sampling technique used. Until sampling techniques are improved, the densities in Table 1 should be considered very tentative.

\section{Protected and unprotected dense forest habitat}

Within a relatively small area $\left(50900 \mathrm{~km}^{2}\right)$, Costa Rica has a well established system of protected wildlands which total some $11679 \mathrm{~km}^{2}$ or $22,9 \%$ of the national territory (Table 5) (Vaughan et al. 1982).

The 26 wildland areas under the supervision of the $\mathrm{Na}$ tional Parks Service total $4130 \mathrm{~km}^{2}(8,1 \%)$ and in general are well protected and largely covered by dense forests. The Forestry Service manages some 24 areas which include $4790 \mathrm{~km}^{2}(9,4 \%)$. They are covered in most cases by $60-90 \%$ dense forest cover, but allow resource exploitation. The Indian Reservations cover some $2693 \mathrm{~km}^{2}$ (5,3\%); however quantity of dense forest cover is unknown and intense hunting pressure exists on wildlife species with some probably locally extinct. Only three Indian Reservations in the Talamanca Mountain Range were used for this report because they are thought to be mostly forest covered.

Wildlands may adjoin each other and together make up a much larger protected area for a species then each one separately. This is the case in Talamanca where Chirripó and La Amistad National Parks, Chirripó, Talamanca, and Tayni Indian Reservations, Río Macho and Los Santos Forest Reserves, Tapantí National Wildlife Refuge and Las Tablas and Barbilla Protected zones together make up some $5179 \mathrm{~km}^{2}$ of protected dense forest for a species such as the jaguar or tapir.

Appendices 1, 2 and 3 summarize protected dense forest habitat area for each species and Table 4 details the largest protected and unprotected vegetation islands, 
TABLE 5

General information on wildland areas in Costa Rica

\begin{tabular}{llccc}
\hline \multicolumn{1}{c}{ Responsible agency } & Wildland category & Quantity & $\begin{array}{c}\text { Total area } \\
\left(\mathbf{k m}^{2}\right)\end{array}$ & $\begin{array}{c}\text { \% of national } \\
\text { territory }\end{array}$ \\
\hline \multirow{3}{*}{ Forestry Service } & Forest Reserve & 11 & 3865,9 & 7,59 \\
& Protected zone & 10 & 849,0 & 1,67 \\
& Wildlife refuge & 3 & $75,3^{*}$ & 0,15 \\
National Parks Service & National Park & 14 & 3938 & 7,74 \\
& Recreational Area & 5 & 6,7 & 0,01 \\
Agricultural Development Institution & Biological Reserve & 6 & 182,7 & 0,36 \\
University of Costa Rica & National Monument & 1 & 2,2 & 0,00 \\
Organization for Tropical Studies & Indian Reservations & 16 & 2693,4 & 5,29 \\
Tropical Science Center & Biological Reserve & 1 & $750^{*}$ & 0,01 \\
& Scientific Reserve & 2 & 17,4 & 0,02 \\
* Tapantí National Wildlife Refuge and Tres de Junio Biological Reserve, so their areas are not computed in the total.
\end{tabular}

estimates population sizes within them and estimates the number with genetically viable populations for long-term fitness. Although several wildand areas were created after 1977 when the last dense forest cover map was made, most areas still were under dense forest cover in 1982 (Fig. $32,33,34)$

\section{Summary of important data for each species}

\section{Cebus capucinus}

This species is adaptable to a variety of forest habitats from sea level to almost $3000 \mathrm{~m}$ including primary and secondary forest, mangrove swamp, and palm swam (Table 1). Between 1940 and 1977, dense forest habitat for the white-faced monkey was reduced 36\% (69-33\%) (Table 3, Fig. 1 and 9). In 1977 there was about $15901 \mathrm{~km}^{2}$ of dense forest habitat for the species of which $8479 \mathrm{~km}^{2}$ (52\%) was protected in wildlands (Table 4 and Fig. 11).

The largest areas or "isolates" of dense forest habitat for this species in 1977 were found in: Talamanca (7900 $\left.\mathrm{km}^{2}\right)$, Chambacú $\left(2741 \mathrm{~km}^{2}\right)$, Irazú $\left(1406 \mathrm{~km}^{2}\right)$ and Osa $\left(1246 \mathrm{~km}^{2}\right)$, while the largest protected areas included La Amistad International Park $\left(1900 \mathrm{~km}^{2}\right)$, Rio Macho Forest Reserve $\left(920 \mathrm{~km}^{2}\right)$, Golfo Dulce Forest Reserve $\left(593 \mathrm{~km}^{2}\right)$ and Los Santos Forest Reserve $\left(533 \mathrm{~km}^{2}\right.$ ) (Table 4)

Between 40290 and 687300 white-faced monkeys inhabit the largest isolate (Talamanca) and 9690-165300 individuals the largest protected area (La Amistad) based on size of the area and density extremes (5,1-87 individuals / $\mathrm{km}^{2}$ ) for the species (Tables 1 and 4).

An area of approximately $98 \mathrm{~km}^{2}$ of dense forest habitat would support a population of 500 individuals based on the lowest density estimation for the species. There are presently 14 "isolates" and 19 protected areas of this size or larger in Costa Rica which could maintain such a genetically viable population for long-term species fitness (Table 4).

The presence of Cebus in altered habitats indicates its adaptability. The white-faced monkey is not under hunting pressure as a game species and although presently legally protected, it is not endangered with extinction in Costa Rica.

\section{Ateles geoffroyi}

The spider monkey inhabits large tracts of dense forest from sea level to about $2500 \mathrm{~m}$ and is considered a wilderness species (Table 1). At Santa Rosa National Park, it is found in 40-60 year old secondary succession forest.

Between 1940 and 1977, dense forest habitat for the spider monkey was reduced 37\% (68-31\%) (Table 3, Fig. 1 and 8). In 1977 there was about $14839 \mathrm{~km}^{2}$ of dense forest habitat for the species of which $7565 \mathrm{~km}^{2}(51 \%)$ was protected in wildlands (Table 4 and Fig. 11).

The largest areas or "isolates" of dense forest habitat for this species as of 1977 were found in: Talamanca $\left(6123 \mathrm{~km}^{2}\right)$, Chambacú $\left(2741 \mathrm{~km}^{2}\right)$, Irazú $\left(1388 \mathrm{~km}^{2}\right)$ and Osa 
$\left(1246 \mathrm{~km}^{2}\right)$, while the largest protected areas included: La Amistad International Park $\left(1647 \mathrm{~km}^{2}\right)$, Rio Macho Forest Reserve $\left(686 \mathrm{~km}^{2}\right)$, Golfo Dulce Forest Reserve $\left(593 \mathrm{~km}^{2}\right)$ and Corcovado National Park ( $418 \mathrm{~km}^{2}$ ) (Table 4)

Between 38208 and 275535 spider monkeys inhabit the largest isolate (Talamanca) and 10277-74115 individuals the largest protected area (La Amistad), based on size of the area and density extremes (6,2-45 individuals $/ \mathrm{km}^{2}$ ) for the species (Tables 1 and 4).

An area of approximately $80 \mathrm{~km}^{2}$ of dense forest habitat would support a population of 500 individuals based on the lowest density estimation for the species. As of 1979, there were 16 "isolates" and 20 protected areas of this size or larger in Costa Rica which could maintain such a genetically viable population for long-term species fitness (Table 4).

The spider monkey is under hunting pressure and is the first primate to be extirpated from a region. It is currently given legal protection and should be considered an endangered species.

\section{Saimiri oerstedii}

The squirrel monkey inhabits a variety of forest habitat from sea level to about 500m in southwestern Costa Rica which include primarily and secondary forests, mangrove and cultivated areas such as banana and African oil palm (Table 1).

Between 1940 and 1977, dense forest habitat for the squirrel monkey was reduced $45 \%$ (75-30\%) (Table 3, Fig. 1 and 4). In 1977 there was about $2143 \mathrm{~km}^{2}$ of dense forest habitat for the species of which $1055 \mathrm{~km}^{2}(49 \%)$ was protected in wildlands (Table 4 and Fig. 13). Because it only occurs in southwest Costa Rica, historically it had the smallest total area of dense forest habitat of any of the species studied.

The largest "isolates" of dense forest habitat for this species as of 1977 were found in: the Osa Peninsula $\left(1246 \mathrm{~km}^{2}\right)$ and along the Fila Costeña $\left(351 \mathrm{~km}^{2}\right)$, while the largest protected areas were: Golfo Dulce Forest Reserve $\left(593 \mathrm{~km}^{2}\right)$ and Corcovado National Park $\left(391 \mathrm{~km}^{2}\right)$ which adjoin each other (Table 4). Between 16198-82236 squirrel monkeys inhabit the largest isolate (Osa Peninsula) and 7709-39138 individuals the largest protected area (Golfo Dulce) based on size of the area and density extremes (13-66 individuals $/ \mathrm{km}^{2}$ ) for the species (Tables 1 and 4).

An area of approximately $8 \mathrm{~km}^{2}$ of dense forest habitat would support a population of 500 individuals based on the lowest density estimation for the species. There are presently 4 isolates and 3 protected areas in Costa Rica of this size or larger which could maintain such a genetically viable population for long-term species fitness (Table 4).

The squirrel monkey is not under hunting pressure and is found close to human settlements. It is legally protected.

\section{Alouatta palliata}

The howler monkey is found in a variety of forested habitats from sea level to $2000 \mathrm{~m}$ including primary and secondary forest in thin bands of trees along water courses in deforested areas (Table 1).

Between 1940 and 1977, dense forest habitat for the howler monkey was reduced 33\% (64-31\%) (Table 3, Fig. 1 and 7). In 1977 there was about $14507 \mathrm{~km}^{2}$ of dense forest habitat for the species of which $6381 \mathrm{~km}^{2}(44 \%)$ was protected in wildlands (Table 4 and Fig. 14).

The largest areas or "isolates" of dense forest habitat for this species in 1977 were found in: Talamanca $\left(3974 \mathrm{~km}^{2}\right)$, Chambacú $\left(2741 \mathrm{~km}^{2}\right)$, Irazú $\left(1187 \mathrm{~km}^{2}\right)$ and Osa $\left(1246 \mathrm{~km}^{2}\right)$, while the largest protected areas included: La Amistad International Park $\left(1133 \mathrm{~km}^{2}\right)$, Golfo Dulce Forest Reserve $\left(593 \mathrm{~km}^{2}\right)$, Cordillera Volcanic Central Forest Reserve $\left(493 \mathrm{~km}^{2}\right)$ and Río Macho Forest Reserve $\left(461 \mathrm{~km}^{2}\right)$, (Table 4).

Between 69545 and 317920 howler monkeys inhabit the largest isolate (Talamanca) and 19828 to 90640 individuals the largest protected area (La Amistad) based on size of the area and density extremes (17,5-80 individuals $/ \mathrm{km}^{2}$ ) for the species (Tables 1 and 4).

An area of approximately $29 \mathrm{~km}^{2}$ of dense forest habitat would support a population of 500 individuals based on the lowest density estimation for the species. There are presently 20 "isolates" and 27 protected areas of this size or larger in Costa Rica which could maintain such a genetically viable population for long-term species fitness (Table 4).

The howler monkey is not threatened in Costa Rica and is found near many rural towns (ie. Nicoya and Upala). Because of its adaptability to altered habitats, and low preferences as a food item by human beings, it is probably the most abundant wild primate in Costa Rica. It is legally protected.

\section{Myrmecophaga tridactyla}

The giant anteater is found in undisturbed swamp forest and dense forest from sea level to about $500 \mathrm{~m}$ elevation (Table 1).

Between 1940 and 1977, dense forest habitat for the giant anteater was reduced 39\% (63-24\%) (Table 3, Fig. 1 and 3). In 1977 there was about $7315 \mathrm{~km}^{2}$ of dense forest habitat for the species of which $1697 \mathrm{~km}^{2}(23 \%)$ was protected in wildlands (Table 4 and Fig. 15). 
The largest areas or "isolates" of dense forest habitat for this species in 1977 were found in: Chambacú $\left(2741 \mathrm{~km}^{2}\right)$ and Osa $\left(1246 \mathrm{~km}^{2}\right)$, while the largest protected areas included: Golfo Dulce Forest Reserve $\left(593 \mathrm{~km}^{2}\right)$, Corcovado National Park $\left(391 \mathrm{~km}^{2}\right)$ and Tortuguero National Park $\left(100 \mathrm{~km}^{2}\right)$ (Table 4).

Three hundred and twenty nine (329) giant anteaters could inhabit the largest isolate (Chambacú) and 71 individuals the largest protected area (Golfo Dulce) based on size of the area and density $\left(0,12\right.$ individuals $\left./ \mathrm{km}^{2}\right)$ for the species (Tables 1 and 4).

An area of approximately $4167 \mathrm{~km}^{2}$ of dense forest habitat would support a population of 500 individuals based on the lowest density estimation for the species. There are presently no "isolates" nor protected areas in Costa Rica of that size or larger which could maintain such a genetically viable population for long-term species fitness (Table 4). Observations of giant anteaters on Fig. 15 were unfortunately confused with Tamandua tetradactyla invalidating that section of the map.

\section{Felis concolor}

The mountain lion is found in a variety of forested habitats from sea level to $3800 \mathrm{~m}$ including primary and secondary forest scrub, mangrove, swamp forest and subalpine paramo (Table 1). Between 1940 and 1977, dense forest habitat for the mountain lion was reduced $34 \%$ (67-33\%) (Table 3, Fig. 1 and 9). In 1977 there was about $15901 \mathrm{~km}^{2}$ of dense forest habitat for the species of which $8479 \mathrm{~km}^{2}(53 \%)$ was protected in wildlands (Table 4 and Fig. 16).

The largest areas or "isolates" of dense forest habitat for the mountain lion were found in: Talamanca $\left(7900 \mathrm{~km}^{2}\right)$, Chambacú $\left(2741 \mathrm{~km}^{2}\right)$, Irazú $\left(1406 \mathrm{~km}^{2}\right)$ and Osa (1246 $\mathrm{km}^{2}$ ), while the largest protected areas included: La Amistad International Park $\left(1900 \mathrm{~km}^{2}\right)$, Rio Macho Forest Reserve $\left(920 \mathrm{~km}^{2}\right)$, Golfo Dulce Forest Reserve $\left(593 \mathrm{~km}^{2}\right)$ and Los Santos Forest Reserve (533 $\mathrm{km}^{2}$ ) (Table 4).

Seven hundred and eleven (711) mountain lions could inhabit the largest isolate (Talamanca) and 171 individuals the largest protected area (La Amistad) based on size of the area and density extremes $\left(0,09\right.$ individuals $\left./ \mathrm{km}^{2}\right)$ for the species (Tables 1 and 4).

An area of approximately $5556 \mathrm{~km}^{2}$ of dense forest habitat would support a population of 500 individuals based on the lowest density estimation for the species. There is presently 1 "isolates" and no individual protected areas in Costa Rica which could maintain such a genetically viable population for long-term species fitness (Table 4).
The mountain lion has one of the lowest densities reported of all the species studied but continues throughout much to the country because of its adaptability to habitat types. Hunting has extirpated the species or reduced it considerably in many areas. The puma should be considered endangered because of low population densities and the fact that it is high on the food chain. It is legally protected.

\section{Felis pardalis}

The ocelot is found in a variety of forested habitats from sea level to $3800 \mathrm{~m}$ including heavily forested areas, secondary forest scrub, mangrove, scrub, pasture, subalpine paramo and even rarely in coffee plantations (Table 1).

Between 1940 and 1977, dense forest habitat for the ocelot was reduced 34\% (67-33\%) (Table 3, Fig. 1 and 9). In 1977 there was about $15901 \mathrm{~km}^{2}$ of dense forest habitat for the species of which $8479 \mathrm{~km}^{2}(53 \%)$ was protected in wildlands (Table 4 and Fig. 17).

The largest areas or "isolates" of dense forest habitat for this species in 1977 were found in: Talamanca $\left(7900 \mathrm{~km}^{2}\right)$, Chambacú $\left(2741 \mathrm{~km}^{2}\right)$, Irazú (1406km²) and Osa (1246km²), while the largest protected areas included: La Amistad International Park (1900 $\mathrm{km}^{2}$ ), Rio Macho Forest Reserve $\left(920 \mathrm{~km}^{2}\right)$, Golfo Dulce Forest Reserve $\left(593 \mathrm{~km}^{2}\right)$ and Los Santos Forest Reserve $\left(533 \mathrm{~km}^{2}\right)$.

Between 1106 and 1975 ocelots could inhabit the largest isolate (Talamanca) and 266 to 475 individuals the largest protected area (La Amistad) based on size of the area and density extremes $\left(0,14-0,25\right.$ individuals $\left./ \mathrm{km}^{2}\right)$ for the species (Tables 1 and 4).

An area of approximately $3571 \mathrm{~km}^{2}$ of dense forest habitat would support a population of 500 individuals based on the lowest density estimation for the species. There is presently 1 "isolate" and no individual protected areas of that size or larger in Costa Rica which could maintain such a genetically viable population for long-term species fitness (Table 4).

The ocelot is adaptable to habitat alteration, however all spotted cats have been intensively hunted for their valuable skins and are probably less abundant than formerly. Because of hunting pressure and the existence of only one area large enough to maintain a viable population in Costa Rica, the ocelot should be considered endangered with extinction. It is legally protected.

\section{Felis wiedii, Felis tigrina}

The margay and the little spotted cat are found in a variety of forested habitats from sea level to $3800 \mathrm{~m}$ including 
heavily forested areas, secondary forest scrub (charral), and mangrove and semi open areas (Table 1).

Between 1940 and 1977, dense forest habitat for the margay and the little spotted cat was reduced 34\% (6733\%) (Table 3, Fig. 1 and 9). In 1977 there was about $15901 \mathrm{~km}^{2}$ of dense forest habitat for the species of which $8479 \mathrm{~km}^{2}(53 \%)$ was protected in wildlands (Table 4 and Fig. 18).

The largest areas or "isolates" of dense forest habitat for this species in 1977 were found in: Talamanca $\left(7900 \mathrm{~km}^{2}\right)$, Chambacú $\left(2741 \mathrm{~km}^{2}\right)$, Irazú $\left(1406 \mathrm{~km}^{2}\right)$ and Osa $\left(1246 \mathrm{~km}^{2}\right)$, while the largest protected areas included: La Amistad International Park $\left(1900 \mathrm{~km}^{2}\right)$, Rio Macho Forest Reserve $\left(920 \mathrm{~km}^{2}\right)$, Golfo Dulce Forest Reserve $\left(593 \mathrm{~km}^{2}\right)$ and Los Santos Forest Reserve $\left(533 \mathrm{~km}^{2}\right)$.

No densities area reported in the literature, so those for Felis pardalis, were used, although I have doubts as to its validity. Between 1106 and 1975 margay and little spotted cats inhabit the largest isolate (Talamanca) and 266 to 475 individuals the largest protected area (La Amistad) based on size of the area and density extremes (0,14-0,25 individuals $/ \mathrm{km}^{2}$ ) for the ocelot (Table 4).

An area of approximately $3571 \mathrm{~km}^{2}$ of dense forest habitat would support a population of 500 individuals based on the lowest density estimation for the species. There is presently 1 "isolate" and no individual protected areas of that size or larger in Costa Rica which could maintain such a genetically viable population for long-term species fitness (Table 4).

The margay and the little spotted cat utilize altered habitats and have been subject to intensive hunting pressure for their valuable skin. Densities are thus probably much lower than in similar habitats where there are not hunted. The species continue to survive in Costa Rica in part because they are found in altered habitats countrywide. They are legally protected.

\section{Felis yagouaroundi}

The smallest of the wild felines is the most variable in habitat use and found from sea level to about $2000 \mathrm{~m}$ elevation in primary and secondary forest, overgrown and grazed pastures (Table 1).

Between 1940 and 1977, dense forest habitat for the jaguarundi was reduced 33\% (64-31\%) (Table 3, Fig. 1 and 7). In 1977 there was about $14507 \mathrm{~km}^{2}$ of dense forest habitat for the species of which $6381 \mathrm{~km}(44 \%)$ was protected in wildlands (Table 4 and Fig. 19).

The largest areas or "isolates" of dense forest habitat for the jaguarundi as of 1977 were found in: Talamanca $\left(3974 \mathrm{~km}^{2}\right)$, Chambacú $\left(2741 \mathrm{~km}^{2}\right)$, Irazú $\left(1246 \mathrm{~km}^{2}\right)$ and
Osa $\left(1189 \mathrm{~km}^{2}\right)$, while the largest protected areas included: La Amistad International Park $\left(1133 \mathrm{~km}^{2}\right)$, Golfo Dulce Forest Reserve $\left(593 \mathrm{~km}^{2}\right)$, Cordillera Volcánica Central and Los Santos Forest Reserve $\left(493 \mathrm{~km}^{2}\right)$ and Rio Macho Forest Reserve $\left(461 \mathrm{~km}^{2}\right)$ (Table 4).

Between 994 and 3179 individuals inhabit the largest isolate (Talamanca) and 283 to 906 individuals the largest protected area (La Amistad) based on size of the area and density extremes $\left(0,25-0,8\right.$ individuals $\left./ \mathrm{km}^{2}\right)$ for the species (Table 4).

An area of approximately $2000 \mathrm{~km}^{2}$ of dense forest habitat would support a population of 500 individuals based on the lowest density estimation for the species. There are presently two large "isolates" and no individual protected areas in Costa Rica which could maintain such a genetically viable population for long-term species fitness (Table 4).

The jaguarandi is found in altered habitats and is under less hunting pressure compared to the other felines because it does not have a valuable fur. In Costa Rica, it will continue to survive especially in altered habitat types and should not be considered an endangered species. It is legally protected.

\section{Panthera onca}

The jaguar is a species found principally in primary forest habitat, from sea level to about $3800 \mathrm{~m}$ elevation in Costa Rica, although it is infrequently reported in the subalpine paramo and semi-altered areas (in Santa Rosa National Park).

Between 1940 and 1977, dense forest habitat for the jaguar reduced 34\% (67-33\%) (Table 3, Fig. 1 and 9). In 1977 there was about $15901 \mathrm{~km}^{2}$ of dense forest habitat for the species of which $8479 \mathrm{~km}^{2}(53 \%)$ was protected in wildlands (Table 4 and Fig. 20).

The largest areas or "isolates" of dense forest habitat for the jaguar were found in: Talamanca $\left(7900 \mathrm{~km}^{2}\right)$, Chambacú $\left(2741 \mathrm{~km}^{2}\right)$, Irazú $\left(1406 \mathrm{~km}^{2}\right)$ and Osa $\left(1246 \mathrm{~km}^{2}\right)$, while the largest protected areas included: La Amistad International Park $\left(1900 \mathrm{~km}^{2}\right)$, Rio Macho Forest Reserve $\left(920 \mathrm{~km}^{2}\right)$, Golfo Dulce Forest Reserve $\left(593 \mathrm{~km}^{2}\right)$ and Los Santos Forest Reserve $\left(533 \mathrm{~km}^{2}\right)$ (Table 4$)$.

Between 110 and 790 jaguars inhabit the largest isolate (Talamanca) and 27 to 190 individuals the largest protected area (La Amistad) based on size of the area and density extremes $\left(0,014-0,1\right.$ individuals $\left./ \mathrm{km}^{2}\right)$ for the species (Tables 1 and 4). An area of approximately $35714 \mathrm{~km}^{2}$ of dense forest habitat would support a population of 500 individuals based on the lowest density estimation for the species. There are presently no large "isolates" nor protected areas in Costa Rica of this size which could mantain 
such a genetically viable population for long-term species fitness (Table 4).

The jaguar is a wilderness species. Unfortunately it will probably become extinct in Costa Rica because of habitat destruction and the fact that it is presently under hunting pressure here. The jaguar would probably have a chance for survival if allowed to exist in altered areas.

\section{Tayassu pecari}

This species is found in humid primary forest from sea level to about $1500 \mathrm{~m}$ but occasionally has been observed in the tropical dry forest in Santa Rosa National Park (Table 1).

Between 1940 and 1977, dense forest habitat for the white-lipped peccary was reduced 37\% (66-29\%) (Table 3, Fig. 1 and 5). In 1977 there was about $12442 \mathrm{~km}^{2}$ of dense forest habitat for the species of which $4807 \mathrm{~km}^{2}$ (39\%) was protected in wildlands (Table 4 and Fig. 21).

The largest areas or "isolates" of dense forest habitat for the species in 1977 were found in: Talamanca $\left(3271 \mathrm{~km}^{2}\right)$, Chambacú $\left(2741 \mathrm{~km}^{2}\right)$, Irazú $\left(944 \mathrm{~km}^{2}\right)$ and Osa $\left(1246 \mathrm{~km}^{2}\right)$, while the largest protected areas included: Golfo Dulce Forest Reserve $\left(593 \mathrm{~km}^{2}\right)$, La Amistad International Park $\left(570 \mathrm{~km}^{2}\right)$, Corcovado National Park $\left(418 \mathrm{~km}^{2}\right)$ and Cordillera Volcánica Central Forest Reserve $\left(381 \mathrm{~km}^{2}\right)$ (Table 4).

Approximately 6524 white-lipped peccaries in inhabit the largest isolate (Chambacú) and 1186 individuals the largest protected area (Golfo Dulce) based on size of the area and density extremes ( 2 individuals $/ \mathrm{km}^{2}$ ) for the collared peccary (Tables 1 and 4).

An area of approximately $250 \mathrm{~km}^{2}$ of dense forest habitat would support a population of 500 individuals based on the lowest density estimation for the collared peccary. At presently there are 10 large "isolates" and four protected areas in Costa Rica of this size which could maintain such a genetically viable population for long-term species fitness (Table 4).

White-lipped peccaries probably forage in large groups (100 individuals or more) over several hundred $\mathrm{km}^{2}$ area while collared peccaries remain in one to four $\mathrm{km}^{2}$ blocks in smaller herds (20-25) which is why I am not convinced of the validity of using this density but did so for discussion purposes. This wilderness species needs extensive tracts of forest habitat to survive and should be classified as an endangered species. It is not currently protected.

\section{Tayassu tajacu}

The collared peccary is found from sea level to almost $3000 \mathrm{~m}$ in a variety of habitats from primary and secondary forest to scrub and overgrown pasture (Table 1).
Between 1940 and 1977, dense forest habitat for the white-lipped peccary was reduced 34\% (67-33\%) (Table 3, Fig. 1 and 9). In 1977 there was about $15901 \mathrm{~km}^{2}$ of dense forest habitat for the species of which $8479 \mathrm{~km}^{2}$ (53\%) was protected in wildlands (Table 3 and Fig. 22).

The largest areas or "isolates" of dense forest habitat for the species in 1977 were found in: Talamanca $\left(7900 \mathrm{~km}^{2}\right)$, Chambacu $\left(2741 \mathrm{~km}^{2}\right)$, Irazu $\left(1406 \mathrm{~km}^{2}\right)$ and Osa $\left(1246 \mathrm{~km}^{2}\right)$, while the largest protected areas included: La Amistad International Park $\left(1900 \mathrm{~km}^{2}\right)$, Río Macho Forest Reserve $\left(920 \mathrm{~km}^{2}\right)$, Golfo Dulce Forest Reserve $\left(593 \mathrm{~km}^{2}\right)$ and Los Santos Forest Reserve $\left(533 \mathrm{~km}^{2}\right.$ ) (Table 4)

Between 15800 and 126000 collared peccaries inhabit the largest isolate (Talamanca) and 3800 to 30400 individuals the largest protected area (La Amistad) based on size of the area and density extremes (2-16 individuals/ $\mathrm{km}^{2}$ ) for the species (Tables 1 and 4).

An area of approximately $250 \mathrm{~km}^{2}$ of dense forest habitat would support a population of 500 individuals based on the lowest density estimation for the species. There are presently nine large "isolates" and eleven protected areas in Costa Rica of this size which could maintain such a genetically viable population for long-term species fitness (Table 4).

The collared peccary is under intensive hunting pressure and is one of the six most important game species in Costa Rica. Its adaptability to altered habitat conditions and high reproductive rate favor continue survival in the country.

\section{Tapirus bairdii}

The tapir is found in a variety of undisturbed habitat types from sea level to about 3800m (Table 1) including primary forest, mangrove, palm swamp, and subalpine paramo. It has been observed in pastures in Santa Rosa National Park. Between 1940 and 1977, dense forest habitat for the tapir was reduced 34\% (67-33\%) (Table 3, Fig. 1 and 9). In 1977 there was about $15901 \mathrm{~km}^{2}$ of dense forest habitat for the species of which $8479 \mathrm{~km}^{2}$ (53\%) was protected in wildlands (Table 4 and Fig. 23).

The largest areas or "isolates" of dense forest habitat for the species in 1977 were found in: Talamanca $\left(7900 \mathrm{~km}^{2}\right)$, Chambacú $\left(2741 \mathrm{~km}^{2}\right)$, Irazú $\left(1406 \mathrm{~km}^{2}\right)$ and Osa $\left(1246 \mathrm{~km}^{2}\right)$, while the largest protected areas included: La Amistad International Park $\left(1900 \mathrm{~km}^{2}\right)$, Río Macho Forest Reserve $\left(920 \mathrm{~km}^{2}\right)$, Golfo Dulce Forest Reserve $\left(593 \mathrm{~km}^{2}\right)$ and Los Santos Forest Reserve $\left(533 \mathrm{~km}^{2}\right)$ (Table 4$)$.

Between 4187 and 4740 tapirs inhabit the largest isolate (Talamanca) and 1007 to 1140 individuals the largest protected area (La Amistad) based on size of the area and 
density extremes $\left(0,53-0,6\right.$ individuals $\left./ \mathrm{km}^{2}\right)$ for Tapirus terrestris (Table 1 and 4).

An area of approximately $943 \mathrm{~km}^{2}$ of dense forest habitat would support a population of 500 individuals based on the lowest density estimation for the species. At presently there are 4 "isolates" and one protected area in Costa Rica of this size or larger in Costa Rica which could maintain such a genetically viable population for long-term species fitness (Table 4).

The tapir is a wilderness species infrequently reported from altered areas where it is probably not under hunting pressure. It maintains scattered populations throughout Costa Rica because of it distribution in large, dense forested areas.

\section{Trichechus manatus}

The sea cow is an aquatic species inhabiting lagoons, estuaries, bays and large rivers on the Atlantic coast of Costa Rica. Attitudinally it is found from sea level to several hundred meters (Table 1 and Fig. 24). It is difficult to calculate habitat destruction because of its specialized aquatic habitat, although the largest dense forest areas are: Chambacú $\left(2741 \mathrm{~km}^{2}\right)$, Tortuguero $\left(567 \mathrm{~km}^{2}\right)$ and areas of palm swamp include Barro Colorado $\left(994 \mathrm{~km}^{2}\right)$. The three areas together from a $4302 \mathrm{~km}^{2}$ block of dense forest and palm swamp habitat with low human density. The most important protected area is Tortuguero National Park. The manatee is probably one of Costa Rica's rarest wildlife species due to past and present hunting pressure and suspected low densities under natural conditions. Densities were not found in the literature. The sea cow is protected as an endangered species.

\section{Harpia harpyja}

This species is found in habitats of primary forest areas from sea level to about $1500 \mathrm{~m}$ (Table 1).

Between 1940 and 1977, dense forest habitat for the harpy eagle was reduced 37\% (66-29\%) (Table 3, Fig. 1 and 5). In 1977 there was about $12442 \mathrm{~km}^{2}$ of dense forest habitat for the species of which $4937 \mathrm{~km}^{2}(40 \%)$ was protected in wildlands (Table 4 and Fig. 25).

The largest areas or "isolates" of dense forest habitat for the species in 1977 were found in: Talamanca $\left(3271 \mathrm{~km}^{2}\right)$, Chambacú $\left(2741 \mathrm{~km}^{2}\right)$, Osa $\left(1246 \mathrm{~km}^{2}\right)$ and Irazú $\left(944 \mathrm{~km}^{2}\right)$, while the largest protected areas included: Golfo Dulce Forest Reserve $\left(593 \mathrm{~km}^{2}\right)$, La Amistad International Park $\left(579 \mathrm{~km}^{2}\right)$, Corcovado National Park $\left(418 \mathrm{~km}^{2}\right)$ and Cordillera Volcánica Central Forest Reserve $\left(381 \mathrm{~km}^{2}\right)$ (Table 4).

Between 26 and 52 harpy eagles inhabit the largest isolate (Talamanca) and 5 to 9 individuals the largest protected area (Golfo Dulce) based on size of the area and density extremes $\left(0,008-0,016\right.$ individuals $\left./ \mathrm{km}^{2}\right)$ for the species (Table 4).

An area of approximately $62500 \mathrm{~km}^{2}$ (larger than Costa Rica) of dense forest habitat would support a population of 500 individuals based on the lowest density estimation for the species. There are presently no isolates nor protected areas of this size or larger in Costa Rica which could maintain such a genetically viable population for longterm species fitness (Table 1 and 4).

It is probably one of the rarest species studied in this report and very few have been reported in Costa Rica in the last five years (Fig. 25). Because it is a wilderness species which needs large extensions of dense forest and is under hunting pressure, the harpy eagle should be classified as an endangered species.

\section{Eagles and Hawk-Eagles (except Harpia harpyja)}

These species are believed to inhabit dense forest areas from sea level to about $1500 \mathrm{~m}$ (Table 1).

Between 1940 and 1977, dense forest habitat for the eagles and hawk-eagles was reduced 37\% (66-29\%) (Table 3, Fig. 1 and 5). In 1977 there was about $12442 \mathrm{~km}^{2}$ of dense forest habitat for the species of which $4937 \mathrm{~km}^{2}(40 \%)$ was protected in wildlands (Table 4 and Fig. 26).

The largest areas or "isolates" of dense forest habitat for the species in 1977 were found in: Talamanca $\left(3271 \mathrm{~km}^{2}\right)$, Chambacú $\left(2741 \mathrm{~km}^{2}\right)$, Osa $\left(1246 \mathrm{~km}^{2}\right)$ and Irazú $\left(944 \mathrm{~km}^{2}\right)$, while the largest protected areas included: Golfo Dulce Forest Reserve $\left(593 \mathrm{~km}^{2}\right)$, La Amistad International Park $\left(579 \mathrm{~km}^{2}\right)$, Corcovado National Park $\left(418 \mathrm{~km}^{2}\right)$ and Cordillera Volcánica Central Forest Reserve $\left(381 \mathrm{~km}^{2}\right)$ (Table 4).

Between 26 and 52 eagles or hawk-eagles for each species are found in the largest isolate (Talamanca) and 5 to 9 individuals in the largest protected area (Golfo Dulce) based on size of the area and density extremes $(0,008$ 0,016 individuals $/ \mathrm{km}^{2}$ ) for the species (Tables 1 and 4).

An area of approximately $62500 \mathrm{~km}^{2}$ (larger than Costa Rica) of dense forest habitat would support a population of 500 individuals based on the lowest density estimation for the species. There are presently no isolates nor protected areas of this size or larger in Costa Rica which could maintain such a genetically viable population for longterm species fitness (Table 4).

Most of these species are considered rare in Costa Rica and need large tracts of dense forest habitat. Also they are usually shot on sight. Probably all eagles and hawk-eagles will go extinct in Costa Rica before the end of the century except for remnant populations found in large protected isolated areas. 


\section{Crax rubra}

This species is found in a variety of forested habitats from sea level to about $2000 \mathrm{~m}$ which include primary and secondary forests, partially cleared areas and scrubby woodlands (Table 1).

Between 1940 and 1977, dense forest habitat for the curassow was reduced 33\% (64-31\%) (Table 3, Fig. 1 and 7). In 1977 there was about $14507 \mathrm{~km}^{2}$ of dense forest habitat for the species of which $6247 \mathrm{~km}^{2}(43 \%)$ was protected in wildlands (Table 4 and Fig. 27).

The largest areas or isolates of dense forest habitat for this species in 1977 were found in: Talamanca $\left(6123 \mathrm{~km}^{2}\right)$, Chambacú $\left(2741 \mathrm{~km}^{2}\right)$, Osa $\left(1246 \mathrm{~km}^{2}\right)$ and Irazú $\left(1187 \mathrm{~km}^{2}\right)$ while the largest protected areas included: La Amistad International Park $\left(1133 \mathrm{~km}^{2}\right)$, Golfo Dulce Forest Reserve $\left(593 \mathrm{~km}^{2}\right)$, Cordillera Volcánica Central Forest Reserve $\left(493 \mathrm{~km}^{2}\right)$ and Río Macho Forest Reserve $\left(461 \mathrm{~km}^{2}\right)$.

Between 1590 and 4769 curassows inhabit the largest isolate (Talamanca) and 453 to 1360 individuals the largest protected area (La Amistad) based on size of the area and density extremes $\left(0,40-1,2\right.$ individuals $\left.\mathrm{km}^{2}\right)$ for the species (Table 1 and 4).

An area of approximately $1250 \mathrm{~km}^{2}$ of dense forest habitat would support a population of 500 individuals based on the lowest density estimation of the species. There are presently one large isolate and no protected area of this size or large in Costa Rica which could maintain such a genetically viable population for long-term species fitness (Table 4).

The great curassow is a favorite game bird and for this reason should be considered endangered. It is not legally protected.

\section{Ara ambigua}

This species is found from sea level to about $1500 \mathrm{~m}$ in the Atlantic coast of Costa Rica in dense tropical lowland forest (occasionally in isolated fruiting trees) (Table 1).

Between 1940 and 1977, dense forest habitat for the green macaw was reduced $42 \%$ (87-45\%) (Table 3, Fig. 1 and 6). In 1977 there was about $8410 \mathrm{~km}^{2}$ of dense forest habitat for the species of which $3197 \mathrm{~km}^{2}$ (38\%) was protected in wildlands (Table 3 and Fig. 28).

The largest areas or isolates of dense forest habitat for this species in 1977 were found in: Chambacú $\left(2907 \mathrm{~km}^{2}\right)$ and Irazú $\left(944 \mathrm{~km}^{2}\right)$ while the largest protected areas included: La Amistad International Park $\left(578 \mathrm{~km}^{2}\right)$, Cordillera Volcánica Central Forest Reserve $\left(381 \mathrm{~km}^{2}\right)$, Rio Macho Forest Reserve $\left(213 \mathrm{~km}^{2}\right)$ and Braulio Carrillo National Park $\left(200 \mathrm{~km}^{2}\right)$.
Between 232 and 698 green macaws inhabit the largest isolate (Chambacú) and 46 to 139 individuals the largest protected area (La Amistad) based on size of the area and density extremes $\left(0,8-0,24\right.$ individuals $\left.\mathrm{km}^{2}\right)$ for the scarlet macaw (Table 1 and 4).

An area of approximately $6250 \mathrm{~km}^{2}$ of dense forest habitat would support a population of 500 individuals based on the lowest density estimation for the species. At present there are not large isolates nor protected areas in Costa Rica which could maintain such a genetically viable population for long-term species fitness (Table 4).

The great green macaw probably covers large areas in feeding. Very little is understood of its biology. It should be considered an endangered species.

\section{Ara macao}

This species is found from sea level to about $1500 \mathrm{~m}$ in tropical lowland forest and occasionally in tall trees in pasture regions (Table 1).

Between 1940 and 1977, dense forest habitat for the scarlet macaw was reduced 37\% (66-29\%) (Table 3, Fig. 1 and 5). In 1977 there was about $12422 \mathrm{~km}^{2}$ of dense forest habitat for the species of which $4937 \mathrm{~km}^{2}$ (40\%) was protected in wildlands (Table 3 and Fig. 29).

The largest areas or isolates of dense forest habitat for this species in 1977 were found in: Talamanca $\left(3271 \mathrm{~km}^{2}\right)$. Chambacú $\left(2907 \mathrm{~km}^{2}\right)$, Osa $\left(1246 \mathrm{~km}^{2}\right)$ and Irazú $\left(944 \mathrm{~km}^{2}\right)$ while the largest protected areas included: Golfo Dulce Forest Reserve $\left(593 \mathrm{~km}^{2}\right)$, La Amistad International Park $\left(578 \mathrm{~km}^{2}\right)$, Corcovado National Park $\left(418 \mathrm{~km}^{2}\right)$ and Cordillera Volcánica Central Forest Reserve $\left(381 \mathrm{~km}^{2}\right)$ (Table 4).

Between 262 and 785 scarlet macaws inhabit the largest isolate (Talamanca) and 47 to 142 individuals the largest protected area (Golfo Dulce) based on size of the area and density extremes $\left(0,08-0,24\right.$ individuals $\left.\mathrm{km}^{2}\right)$ for the species (Table 4).

An area of approximately $6250 \mathrm{~km}^{2}$ of dense forest habitat would support a population of 500 individuals based on the lowest density estimation of the species. At present there are not large isolates nor protected areas in Costa Rica which could maintain such a genetically viable population for long-term species fitness (Table 4).

\section{Pharomachrus mocinno}

This species is found between 1000 and 3000m elevation in primary forest and occasionally in isolated fruiting trees near forests. (Table 1)

Between 1940 and 1977, dense forest habitat for the quetzal was reduced for only 19\% (79-60\%) (Table 3, Fig. 1 and 10). In 1977 there was about $6730 \mathrm{~km}^{2}$ of dense forest 
habitat for the species of which $5412 \mathrm{~km}^{2}$ (80\%) was protected in wildlands (Table 3 and Fig. 30 ).

The largest areas or isolates of dense forest habitat for this species in 1977 were found in: Talamanca $\left(4766 \mathrm{~km}^{2}\right)$ and Irazú $\left(835 \mathrm{~km}^{2}\right)$ and San Ramón $\left(579 \mathrm{~km}^{2}\right)$ while the largest protected areas included: La Amistad International Park $\left(1723 \mathrm{~km}^{2}\right)$, Río Macho Forest Reserve $\left(870 \mathrm{~km}^{2}\right)$, Cordillera Volcánica Central Forest Reserve $\left(468 \mathrm{~km}^{2}\right)$ and Los Santos Forest Reserve $\left(436 \mathrm{~km}^{2}\right)$ (Table 4).

Between 12868 and 13821 quetzals inhabit the largest isolate (Talamanca) and 4652 to 4997 individuals the largest protected area (La Amistad) based on size of the area and density extremes $\left(2,7-2,9\right.$ individuals $\left./ \mathrm{km}^{2}\right)$ for the species (Table 4).

An area of approximately $185 \mathrm{~km}^{2}$ of dense forest habitat would support a population of 500 individuals based on the lowest density estimation of the species. There are presently three large dense forested areas and nine protected areas in Costa Rica which could maintain such a genetically viable population for long-term species fitness (Table 4).

The quetzal is found in forested highland mountains (watersheds), the least altered vegetation type in the country. It is not endangered in Costa Rica, although it is occasionally shot.

\section{Caiman crocodilus}

This species is found in low land freshwater rivers, marshes and lakes in Costa Rica from sea level to about $500 \mathrm{~m}$.

Between 1940 and 1977, dense forest habitat for the caiman was reduced 39\% (63-24\%) (Table 3, Fig. 1 and 3). In 1977 there was about $7315 \mathrm{~km}^{2}$ of dense forest habitat for the species of which $1697 \mathrm{~km}^{2}$ (23\%) was protected in wildlands (Table 3 and Fig. 30).

There also exists approximately $1979 \mathrm{~km}^{2}$ of mangrove and swamps and an unknown quantity of riparian habitats. The largest areas or isolates of dense forest habitat for this species in 1977 were found in: Chambacú $\left(2741 \mathrm{~km}^{2}\right)$, Osa $\left(1246 \mathrm{~km}^{2}\right)$, Tortuguero $\left(567 \mathrm{~km}^{2}\right)$ and that of palm swamp, including Barro Colorado $\left(994 \mathrm{~km}^{2}\right)$. Chambacú, Tortuguero, and Barro Colorado together form a $4305 \mathrm{~km}^{2}$ block of dense forest and palm swamp habitat with low human density. The largest protected areas with dense forest habitat included Golfo Dulce Forest Reserve $\left(593 \mathrm{~km}^{2}\right)$ Corcovado National Park $\left(391 \mathrm{~km}^{2}\right)$ and Tortuguero $\mathrm{Na}-$ tional Park $\left(100 \mathrm{~km}^{2}\right)$. Densities for this species were not found in the literature. Its status is unknown although it is frequently hunted and its populations have been reduced in many areas where it was formally abundant.

\section{Crocodylus acutus}

The crocodile is an inhabitant of low land salt, brackish or freshwater habitat from sea level to about $500 \mathrm{~m}$.

Between 1940 and 1977, dense forest habitat for the green macaw was reduced 39\% (63-24\%) (Table 3, Fig. 1 and 3). In 1977 there was about $7315 \mathrm{~km}^{2}$ of dense forest habitat for the species of which $1697 \mathrm{~km}^{2}(22 \%)$ was protected in wildlands (Table 3 and Fig. 31).

There also exists approximately $1979 \mathrm{~km}^{2}$ of mangrove and swamps and an unknown quantity of river habitats. The largest areas or isolates of dense forest habitat for this species in 1977 were found in: Chambacú $\left(2741 \mathrm{~km}^{2}\right)$ Osa $\left(1246 \mathrm{~km}^{2}\right)$, Tortuguero $\left(567 \mathrm{~km}^{2}\right)$ and that of palm swamp, including Barro Colorado $\left(994 \mathrm{~km}^{2}\right)$. Chambacú, Tortuguero, and Barro Colorado together form a $4305 \mathrm{~km}^{2}$ block of dense forest and palm swamp habitat with low human density. The largest protected areas with dense forest habitat included Golfo Dulce Forest Reserve $\left(593 \mathrm{~km}^{2}\right)$, Corcovado National Park $\left(391 \mathrm{~km}^{2}\right)$ and Tortuguero National Park $\left(100 \mathrm{~km}^{2}\right)$. Densities for this species were not found in the literature. It is considered endangered throughout its range because of hunting pressure and habitat destruction.

\section{Ranking of endangered wildlife species studied}

The objectives of this section are to determine and compare the status of species in Costa Rica based principally on biological data presented thus far.

Other ideas have been presented to classify endangered species (see Ehrenfeld 1972 \& Wilcox 1980).

The criteria used here include: (a) species relative density, (b) dense forest habitat in 1977, (c) rate of destruction of dense forest habitat, (d) hunting pressure, (e) adaptability to altered habitats, (f) biotic potential and (g) number of dense forest areas in Costa Rica with possible genetically viable populations for the species (Table 6). For each parameter, the animal was classified on a 1 to 4 scale, with 4 indicating low density, small amount of dense forest habitat, great hunting pressure, and 1 being the opposite extreme.

Admittedly it is difficult to know which factors are the most important for the survival of a species. For instance, Saimiri oerstedii is apparently not threatened compared to other species (Table 7). However, it has the smallest quantity of dense forest habitat area of any species studied and only three vegetation islands with supposed genetically viable populations. On the other hand, troops survive in altered habitats and hunting pressure is low. However, Trichechus manatus and Myrmecophaga tridactyla are both rare, unadaptable to altered conditions, with low 
TABLE 6

Status of endangered wildlife species in Costa Rica based on major contributing biological factors

\begin{tabular}{|c|c|c|c|c|c|c|c|c|}
\hline Species & $\begin{array}{l}\text { Relative } \\
\text { density }\end{array}$ & $\begin{array}{c}\text { Dense forest } \\
\text { habitat (1977) }\end{array}$ & $\begin{array}{c}\text { Rate of } \\
\text { dense forest } \\
\text { destruction }\end{array}$ & $\begin{array}{l}\text { Hunting } \\
\text { pressure }\end{array}$ & $\begin{array}{c}\text { Adaptability } \\
\text { to altered } \\
\text { habitats }\end{array}$ & $\begin{array}{c}\text { Biotic } \\
\text { potential }\end{array}$ & $\begin{array}{c}\text { Number of } \\
\text { areas with } \\
\text { genetically } \\
\text { viable } \\
\text { populations }\end{array}$ & Total \\
\hline Cebus capucinus & 1 & 1 & 2 & 2 & 2 & 2 & 1 & 11 \\
\hline Ateles geoffroyi & 3 & 2 & 2 & 4 & 4 & 2 & 2 & 19 \\
\hline Saimiri oerstedii & 1 & 4 & 3 & 2 & 2 & 2 & 4 & 18 \\
\hline Alouatta palliata & 1 & 3 & 2 & 2 & 2 & 2 & 1 & 13 \\
\hline $\begin{array}{l}\text { Myrmecophaga } \\
\text { tridactyla }\end{array}$ & 4 & 4 & 2 & 3 & 4 & 4 & 4 & 25 \\
\hline Felis concolor & 4 & 1 & 2 & 4 & 2 & 3 & 4 & 20 \\
\hline Felis pardalis & 4 & 1 & 2 & 4 & 3 & 3 & 4 & 21 \\
\hline $\begin{array}{l}\text { Felis wiedii (a) } \\
\text { Felis tigrina }(b)\end{array}$ & 4 & 1 & 2 & 4 & 3 & 3 & 4 & 21 \\
\hline Felis yagouaroundi & 3 & 3 & 2 & 3 & 2 & 3 & 4 & 20 \\
\hline Panthera onca & 4 & 1 & 2 & 4 & 4 & 3 & 4 & 22 \\
\hline Tayassu pecari & 3 & 3 & 2 & 4 & 4 & 2 & 4 & 22 \\
\hline Tayassu tajacu & 2 & 1 & 2 & 4 & 2 & 2 & 4 & 16 \\
\hline Tapirus bairdii & 3 & 1 & 2 & 4 & 3 & 4 & 4 & 21 \\
\hline Trichechus manatus & 4 & 3 & 3 & 4 & 4 & 4 & 4 & 26 \\
\hline Harpia harpyja & 4 & 3 & 2 & 4 & 4 & 4 & 4 & 25 \\
\hline $\begin{array}{l}\text { Eagles and Hawk- } \\
\text { eagles }\end{array}$ & 4 & 3 & 2 & 4 & 4 & 4 & 4 & 25 \\
\hline Crax rubra & 3 & 3 & 2 & 4 & 3 & 3 & 3 & 21 \\
\hline Ara ambigua & 3 & 3 & 2 & 3 & 3 & 3 & 4 & 21 \\
\hline Ara macao & 3 & 3 & 2 & 3 & 3 & 3 & 4 & 21 \\
\hline $\begin{array}{l}\text { Pharomachrus } \\
\text { mocinno }\end{array}$ & 2 & 3 & 1 & 2 & 3 & 3 & 4 & 18 \\
\hline Crocodylus acutus & 4 & 4 & 4 & 4 & 3 & 2 & 3 & 24 \\
\hline Caiman crocodiles & 2 & 4 & 4 & 4 & 2 & 2 & 3 & 21 \\
\hline
\end{tabular}

biotic potential and the giant anteater has little remaining dense forest habitat and no areas for genetically viable populations. The manatee is also under extreme hunting pressure.

Results from Table 7 indicate that the most threatened wildlife species are: Trichechus manatus, Myrmecophaga tridactyla, Harpia harpyja and all other Eagles and Hawkeagles, Panthera onca and Tayassu pecari. This could have been predicted from previous sections. None of these species will probably maintain genetically viable populations in Costa Rica and in the next decades or centuries will probably become extinct (Wilcox 1980). At the other extremes of ranking, Cebus capucinus, Alouatta palliata, and Tayassu tajacu are species thought to have sizable populations in Costa Rica, large extensions of dense forest habitat, adaptable to secondary (altered) habitats and with several areas of dense forest habitat large enough for genetically viable populations. 
TABLE 7

Ranking of endangered wildlife species in Costa Rica based on biological data

\begin{tabular}{lc}
\hline Species & Rank \\
\hline Trichechus manatus & 26 \\
Myrmecophaga tridactyla & 25 \\
Harpia harpyja & 25 \\
Eagles and Hawk eagles & 25 \\
Crocodylus acutus & 24 \\
Panthera onca & 22 \\
Tayssau pecari & 22 \\
Crax rubra & 21 \\
Felis pardalis & 21 \\
Tapirus bairdii & 21 \\
Ara macao & 21 \\
Ara ambigua & 21 \\
Caiman crocodilus & 21 \\
Felis wiedii - Felis tigrina & 21 \\
Felis yagouaroundi & 20 \\
Felis concolor & 20 \\
Ateles geoffroyi & 19 \\
Saimiri oerstedii & 18 \\
Pharomachrus mocinno & 18 \\
Tayassau tajacu & 16 \\
Alouatta palliata & 13 \\
Cebus capucinus & 11
\end{tabular}

\section{CONCLUSIONS}

1. It is possible to quantify existence and loss of dense forest for some wildlife species and it clarifies to some degree the endangered species concept.

2. Recent developments in the field of insular ecology have shown the importance of carefully planning the creation of wildland areas as habitat islands for the existence and perpetuation of wildlife species.

3. Most of the wildlife species studied suffered around $35 \%$ dense forest habitat destruction from 19401977 with the extremes being Saimiri oerstedii (45\%) and Pharomachrus mocinno (19\%).

4. If dense forest block sizes, densities and the idea that 500 individuals are necessary for long term fitness are correct as presented, a number of wildlife species will become extinct within $50-150$ years in Costa Rica because there are no dense forest areas large enough for 500 individuals. These wildlife species included: Myrmecophaga tridactyla, all Felis except Felis yagouaroundi, Harpia hapyja, Eagles and Hawk-eagles, Ara ambigua and Ara macao. Several other species are adaptable to altered conditions which may increase their probabilities of survival.

5. Most other species have at least one protected area where a genetically viable population can persist. Unfortunately many sizable areas of their habitat are not being protected at present and thus the opportunity for ensuring a viable population will be lost.

6. The most important protected areas in Costa Rica for the survival of the species studied are: low elevation: (0-750m) Corcovado National Park-Golfo Dulce Forest Reserve Complex. Middle and high elevations: (200-3400m) Braulio Carrillo National Park-Cordillera Volcánica Central Forest Reserve-La Selva Protected Zone-La Selva Biological Reserve Complex. Middle and high elevations: (2000-3800m) Chirripó National Park-La Amistad International Park-Río Macho and Los Santos Forest Reserves-Barbilla and Las Tablas Protected Zones-Talamanca, Chirripó, Ujarrás and Tayni-Telire Indian Reservations Complex.

7. Another area currently not under protection but important for wildlife species is Chambacú near the Nicaraguan border which could include all swamp and dense forest areas to Tortuguero National Park.

8. Those species considered most endangered according to biological parameters include: Trichechus manatus, Mymecophaga tridactyla, Harpia harpyja, other Eagles and Hawk-eagles, Crocodylus acutus, Panthera onca and Tayassu pecari.

9. Much research is needed on the wildlife species studies to determine more accurately their distribution in Costa Rica, densities and population dynamics. Present information is inadequate, and this report represents an initial effort in this direction.

10. Most species could probably survive in altered areas if they were not under hunting pressure. Management programs should take this into account.

\section{ACKNOWLEDGEMENTS}

The following persons were instrumental in different aspects of the publication of this document: Francisco Hodgson drew all maps, Floyd Gray measured areas in the maps, Mayra Alfaro and some twelve forestry students of the Environmental Sciences School carried out field 
interviews and Jorge Barrantes, Lucía Vargas and Marielos Vargas typed up several drafts including the final one. Finally Dan Janzen, Wayne Melquist, Jerry Wilkinson and Michael McCoy constructively criticized several drafts. To all of them I am grateful. Funded by the United States Department of the Interior (Contract No. 14-16-009-79-055), the National University (Research Project No. 782085) and The Parrot Society-UK. This publication was originally mimeographed at the Universidad Nacional as "A Report on Dense Forest Habitat for endangered wildlife species in Costa Rica" by the author in 1983 in response to the lack of information on Costa Rican endangered species and the publication of Conservation Biology (Soule and Wilcox, eds. 1980). Updated information using Geographical Information Systems (GIS) systems were incorporated in 1998 in the book, "GIS Methodologies for Developing Conservation Strategies" (Savitsky and Lacher, 1998) where two chapters referring to the Vaughan 1983 study (Savitsky et al. 1998; Vaughan et al 1998)

\section{REFERENCES}

Baldwin, J. \& J. Baldwin, 1972. The ecology and behavior of squirrel monkeys (Saimiri oerstedii) in a natural forest in Western Panama. Folia Primatologia 18: 161-182.

Carpenter, C. 1935. A field study of the behavior and social relations of the howling monkeys (Alouatta palliata). Comparative Psychology Monographs 10: 1-168.

Caughley, G. 1977. Analysis of Vertebrate Populations. John Wiley \& Sons. New York, USA.

Diamond, J. 1975. The island dilemma: lesson of modern biogeographic studies for the design of natural preserves. Biological Conservation 7: 129-146.

Dirección General Forestal. 1979. Cobertura de bosques en Costa Rica. Esc. 1:1.000.000 (colores). Dirección General Forestal, San José, Costa Rica

Ehrenfeld, D. 1972. Conservación y Biología. Interamericana. México D.F., México.

Eisenberg, J. 1980. The density and biomass of tropical mammals, p. 35-55, In M. Soulé \& B. Wilcox (eds). Conservation Biology. Sinauer, Massachusetts, USA.

Fosberg, F. 1973. Temperate zone influence of tropical land use: A plea for sanity, p. 345-350, In B. Meggers, E. Ayensu \& W. Duckworth (eds). Tropical Forest Ecosystems in Africa and South America: A Comparative Review. Smithsonian Institute, Washington, USA.

Foster, R. 1980. Heterogeneity and disturbance in tropical vegetation, p. 95-117, In M. Soulé \& B. Wilcox (Eds). Conservation Biology. Sinauer, Massachusetts, USA.

Frankel, W. \& M. Soulé. 1981. Conservation and Evolution. Cambridge University, New York, USA.
Franklin, F. 1980. Evolutionary change in small populations, p. 135-149, In: M. Soulé \& B. Wilcox (eds). Conservation Biology. Sinauer, Massachusetts, USA.

Freese, C. 1975. Censusing Alouatta palliata, Ateles geoffroyi and Cebus capucinus in the Costa Rica dry forest, p. 4-9, In R. Thorington \& P. Helthe (eds). Neotropical Primates: Field Studies and Conservation. Washington D.C., USA.

Goodwin, G. 1946. Mammals of Costa Rica. Bulletin of the Museum of Natural History. New York, USA.

Hall, E. \& K. Kelson, 1959. The Mammals of North America. Ronald Press, New York, USA.

Handley, C. 1950. Game mammals of Guatemala, p. 141-162, In R.B. Saunders, A. Holloway \& O. Handley (eds). A Fish and Wildlife Survey of Guatemala. U.S. Department of the Interior, Washington D.C., USA.

Henderson, C. 1969. Fish and Wildlife Resources in Costa Rica with Notes on Human Influence. M.S. Thesis, University of Georgia, Athens, Gerogia, USA.

Hornocker, M. 1969. Winter territoriality in mountain lions. Journal of Wildlife Managment 33: 347-464.

International Union for the Conservation of Nature and Natural Resources. 1976. Red Data Book. IUCN, Berne, Switzerland.

International Union for the Conservation of Nature and Natural Resources. 1978. Threatened vertebrates. IUCN, Berne, Switzerland.

Johnson, W. \& C. Vaughan. 1993. Habitat use of small terrestrial rodents in the Costa Rican highlands. Revista de Biologia Tropical 41: 521-527

Land. H. 1970. Birds of Guatemala. Livingston Publishing Company, Pennsylvania, USA.

Lande, R. 1976. The maintenance of genetic variability by mutation in a polygenetic character with linked loci. Genetic Research Cambridge 26: 221-35.

Leopold, A. 1965. Fauna Silvestre de México. Instituto Mexicano de Recursos Naturales Renovables, México.

MacArthur, R. \& E. Wilson. 1967. The Theory of Island Biogeography. Princeton University, New Jersey, USA.

Mendez, E. 1974. Los Principales Mamiferos Silvestres de Panama. Edicion Privada. Panama. 283 p.

Myers, N. 1980. Conservation of Tropical Moist Forest. National Academy of Sciences, Washington, D.C., USA.

Oficina de Planificación del Sector Agropecuario. 1979. Comportamiento del sector forestal durante el período 19501977. O.P.S.A., San José, Costa Rica.

Oppenheimer, J. 1968. Behaviour and ecology of the White-faced monkey, Cebus capucinus, on Barro Colorado Island, C.Z. Ph.D Thesis. University of Illinois, Urbana. Illinois, USA.

Peterson, R. \& E. Chalif. 1973. A Field Guide to Mexican Birds. Houghton Mifflin Co., Boston, USA. 
Pickett, S. \& J. Thompson. 1978. Patch dynamics and the design of nature reserves. Biological Conservation 13: 27-37

Poder Ejecutivo. 1969. Ley de conservación de fauna Silvestre. La Gaceta, San José, Costa Rica.

Ridgeley, R. 1976. A Guide to the Birds of Panama. Princeton University, New Jersey, USA. 394 p.

Savitsky, B., J. Fallas, C. Vaughan \& T. Lacher. 1998. Wildlife and habitat data collection and analysis. p. 145-153, In B. Savitsky \& T. Lacher (eds.). GIS methodologies for developing conservation strategies. Columbia University Press, New York.

Savitsky, B. \& T. Lacher (eds). 1998. GIS methodologies for developing conservation strategies. Columbia University Press, New York.

Schaller, G. \& P. Crawshaw, 1980. Movement patters of jaguar. Biotropica 12: 161-168.

Skutch, A. 1964. Life history of the quetzal. The Condor 48: 213-235.

Slud, P. 1964. The Birds of Costa Rica: Distribution and Ecology. Bulletin American Museum of Natural History 128: 1-430.

Stiles, G. 1981. Comunicacion personal.

Soule, M. \& B. Wilcox (eds). 1980. Conservation Biology. Sinauer, Massachusetts. 395 p.

Terborgh, J. 1974. Faunal equilibria and the design of wildlife preserves, p. 369-80, In F. Golley \& E. Medina (Eds.). Tropical Ecological Systems: Trends in Terrestrial and Aquatic Research. Springer-Verlay, New York, USA.
U.S. Department of State. 1981. The world's tropical forests: A U.S. policy, strategy and program. U.S. Dept. of State. Washington, D.C., USA.

Vaughan, C. 1978. Una metodología para determinar la distribución actual y datos sobre el estado actual de especies de la fauna silvestre con énfasis de aquellas en vía de extinción. Memorias de la Primera Reunión Regional Centroamericana sobre Vida Silvestre. CATIE, Turrialba, Costa Rica.

Vaughan, C. 1981. Parque Nacional Corcovado: Plan de Manejo y Desarrollo. EUNA, Heredia, Costa Rica.

Vaughan, C., G. Canessa, M. McCoy, M. Rodríguez, J. Bravo, J. Sánchez, R. Morales, T. Hawkins, D. Shaffer, E.Crozier, M. Rodríguez \& F. Hodgson. 1982. Dr. Rafael Lucas Rodríguez Caballero Wildlife Refuge (Palo Verde): Plan de Manejo y Desarrollo. Editorial de la Universidad Nacional, Heredia, Costa Rica.

Vaughan, C., J. Fallas \& M. McCoy. 1998. Conservation mapping in Costa Rica. p.. 20-32, In B. Savitsky \& T. Lacher (eds). GIS methodologies for developing conservation strategies. Columbia University Press, New York.

Vaughan, C. \& M. McCoy. 1984. Population estimation for some mammal species in Manuel Antonio National Park, Costa Rica. Brenesia 22: 207-217.

Whitmore, T. 1980. The conservation of tropical rain forest, $\mathrm{p}$. 303-318, In M. Soulé. \& B. Wilcox (eds). Conservation Biology. Sinauer, Massachusetts, USA.

Wilcox, B. 1980. Insular ecology and conservation, p. 95-118, In M. Soulé \& B. Wilcox (eds). Conservation Biology. Sinauer, Massachusetts, USA. 


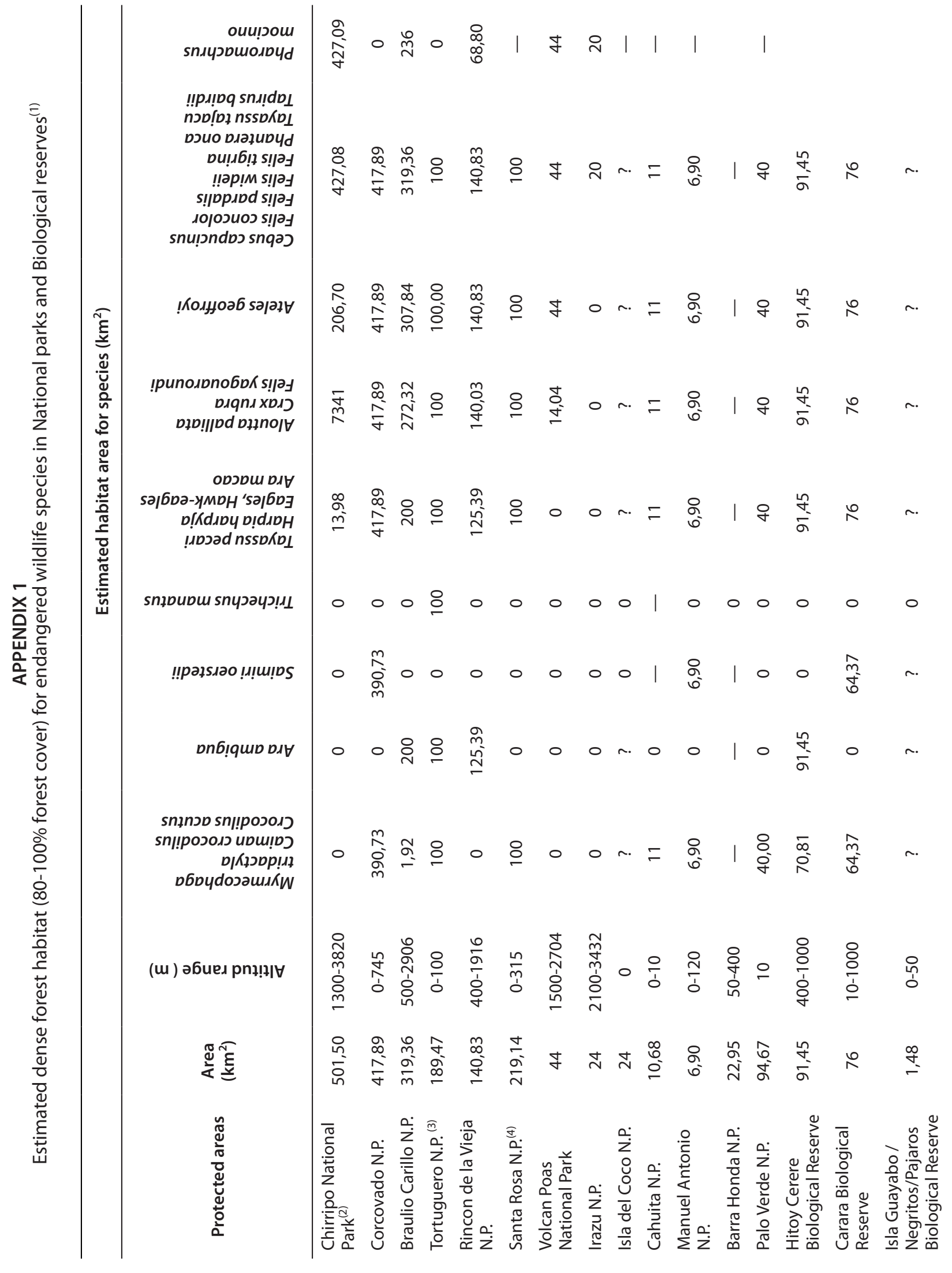




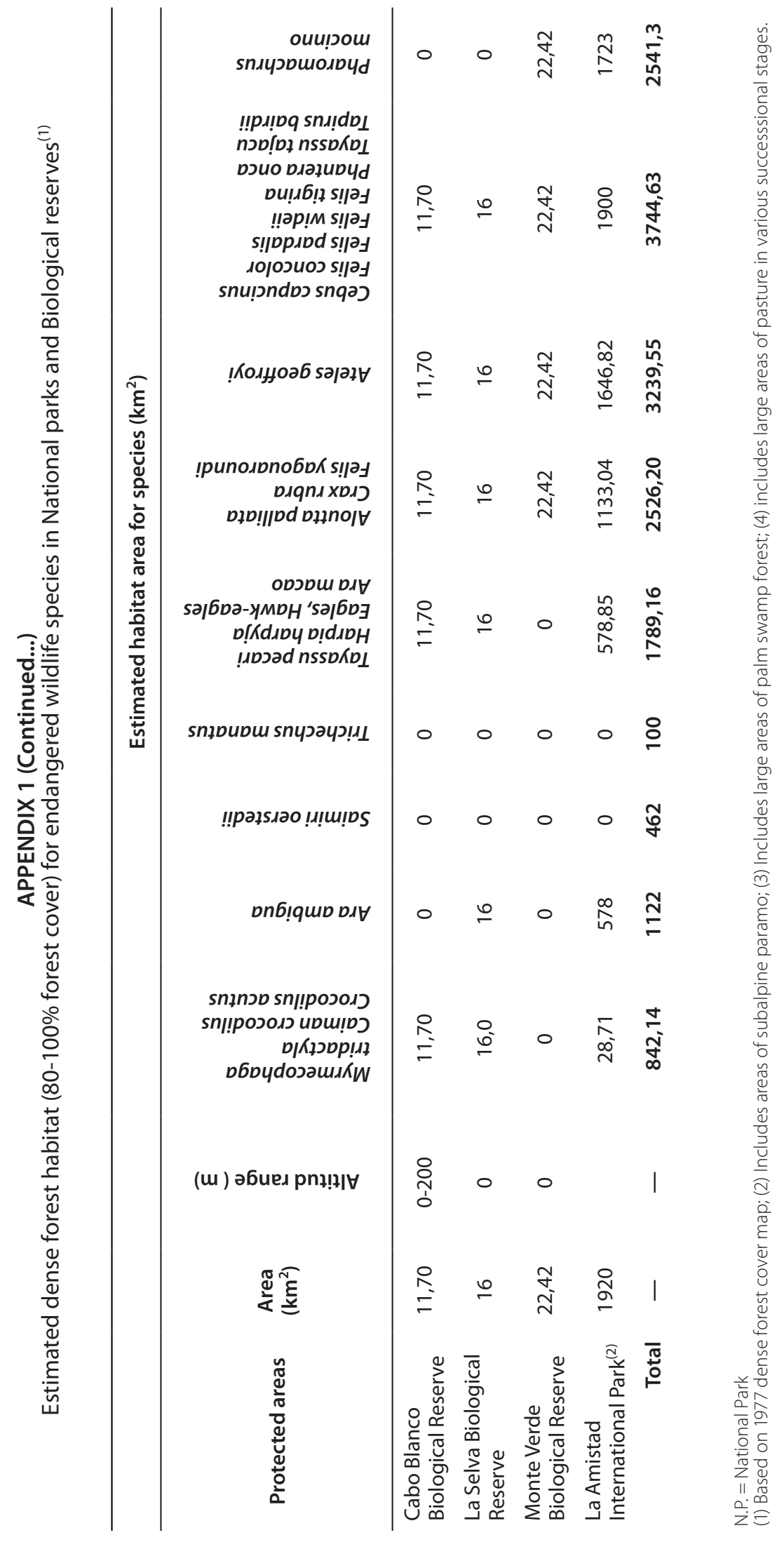




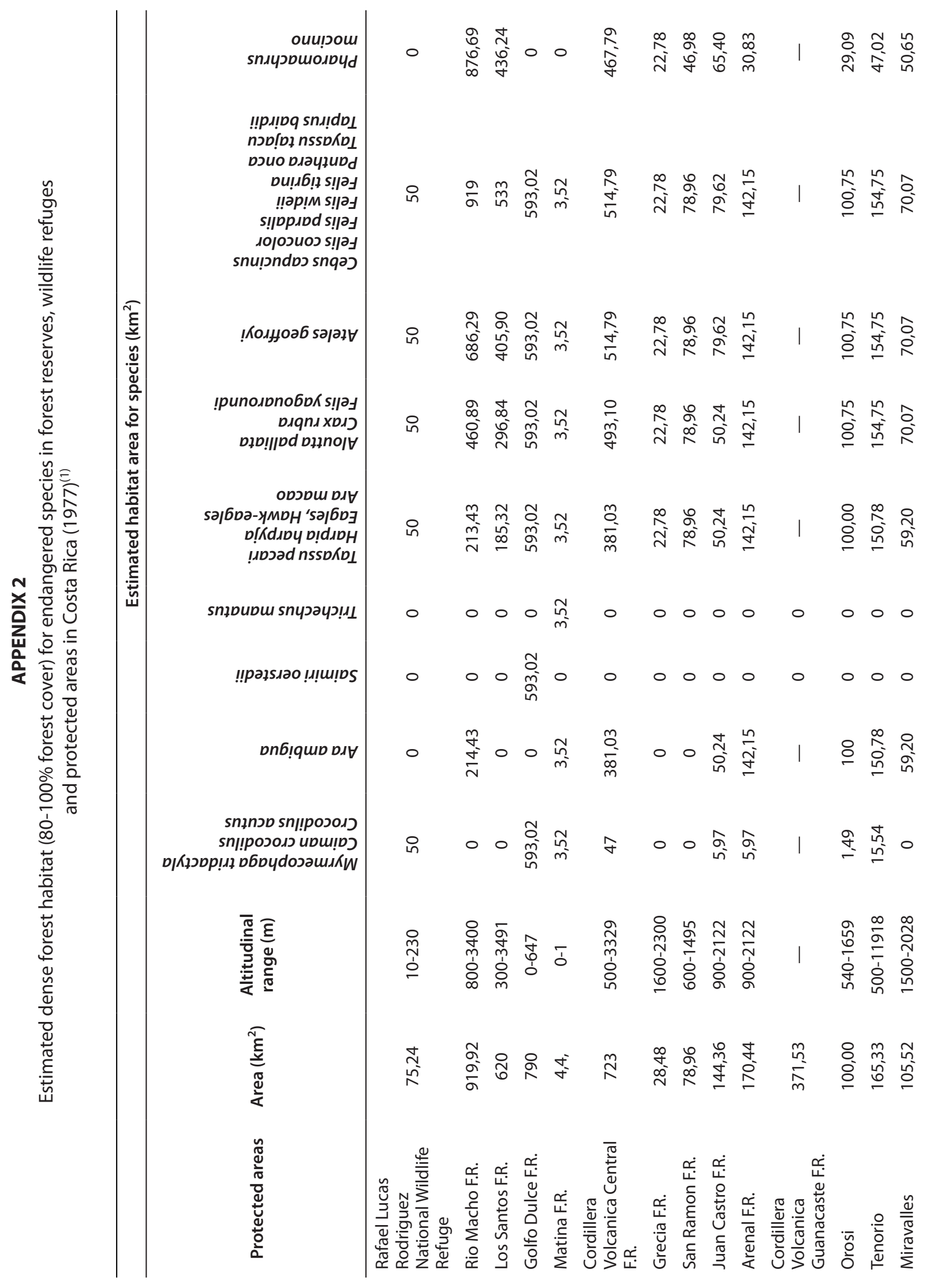



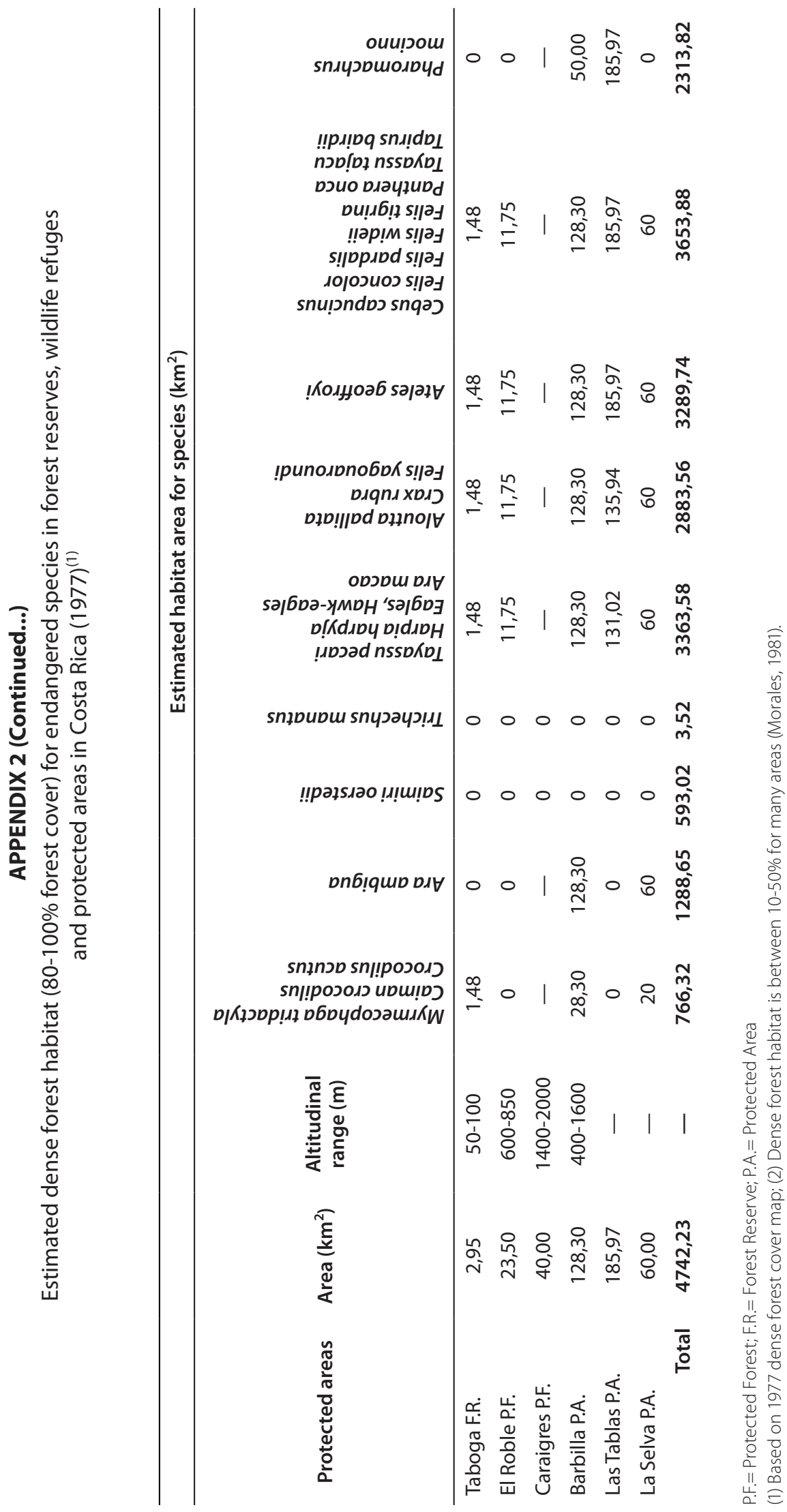


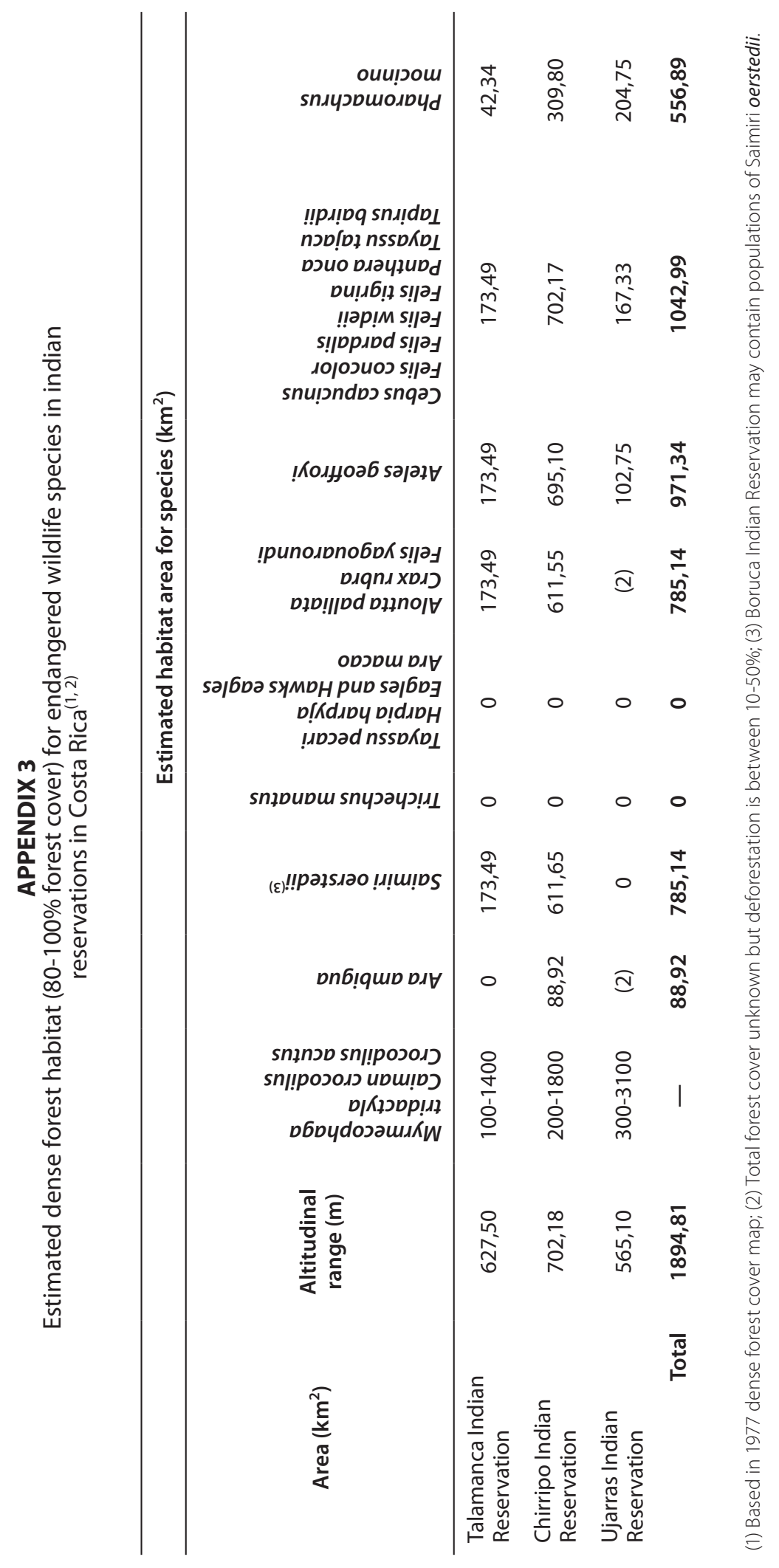



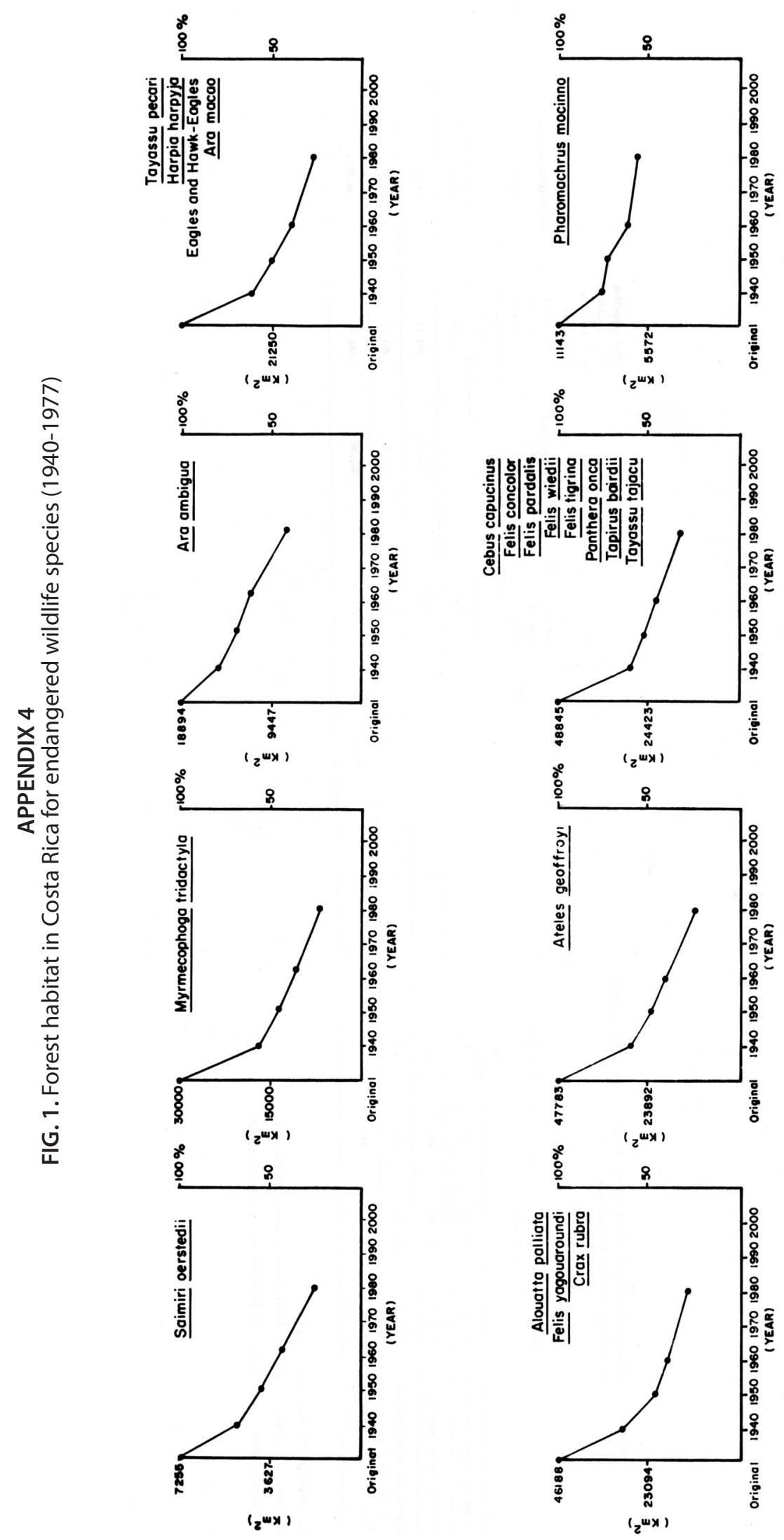
APPENDIX 5

Figures 2-33.

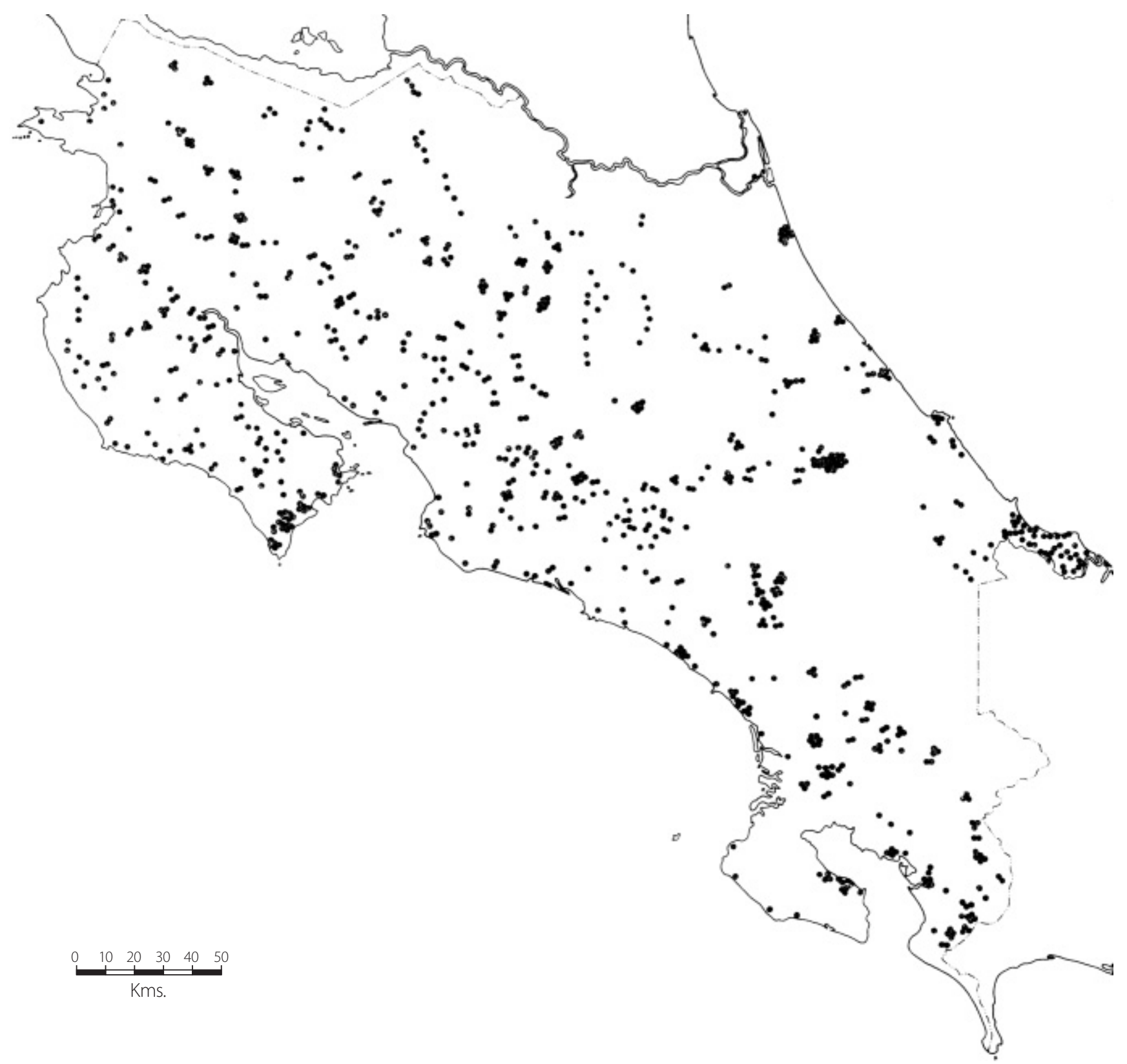

FIG. 2. Interview sites. 


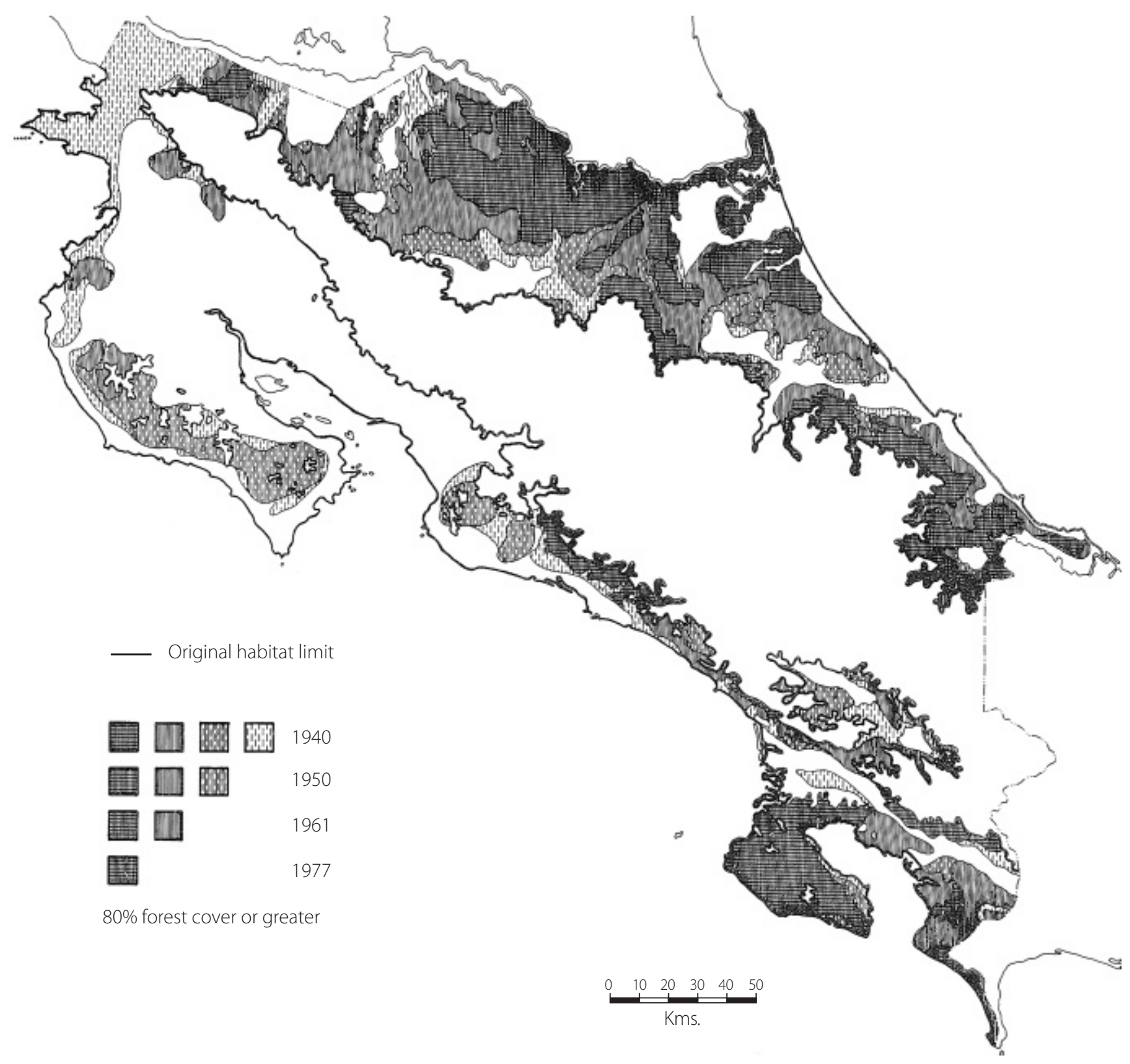

FIG. 3. Forest habitat in Costa Rica (1940-1950-1961-1977) for the species Myrmecophaga tridactyla, Crocodylus acutus and Caiman crocodilus. 


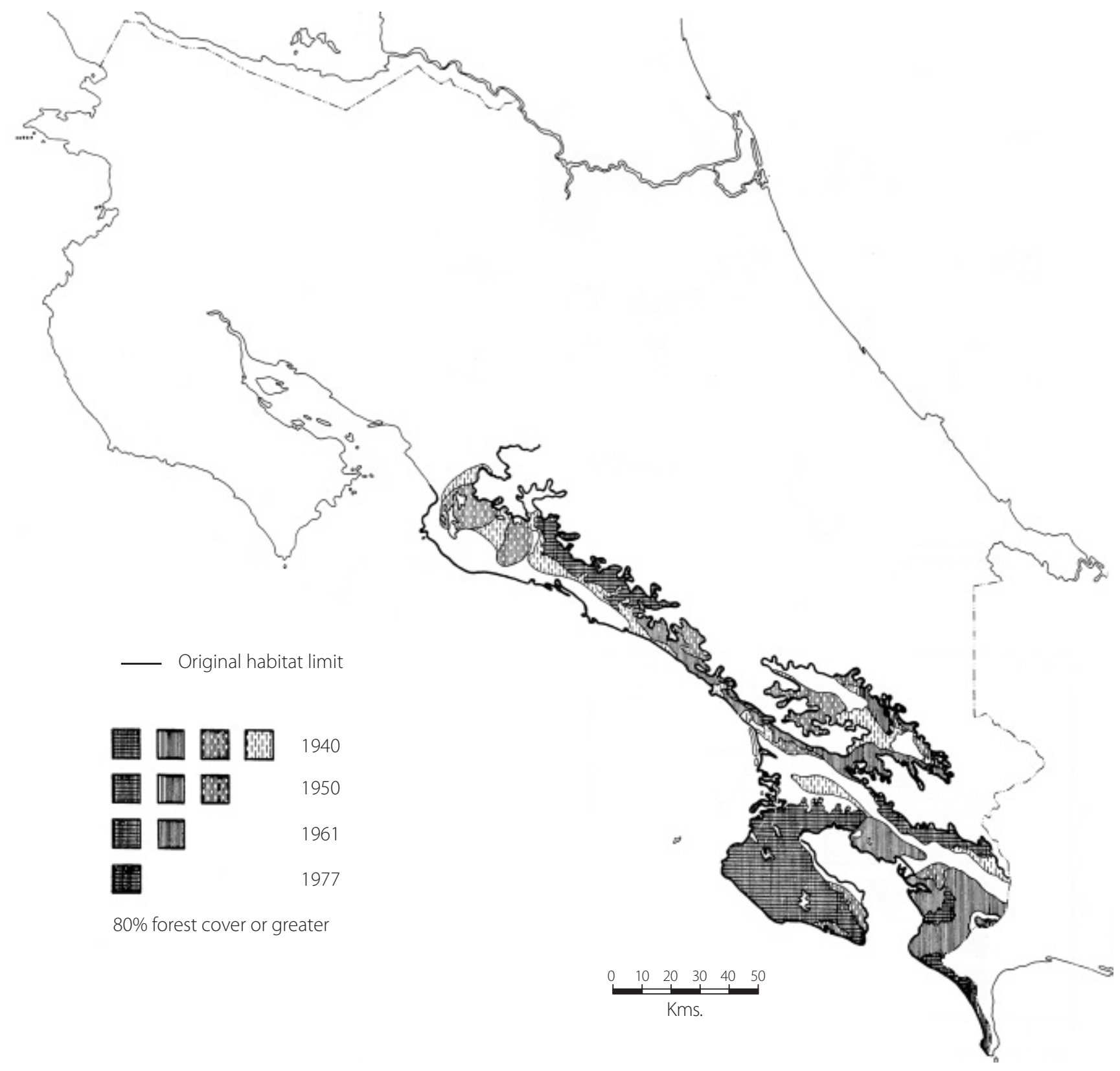

FIG. 4. Forest habitat in Costa Rica (1940-1950-1961-1977) for the species Saimiri oerstedii. 


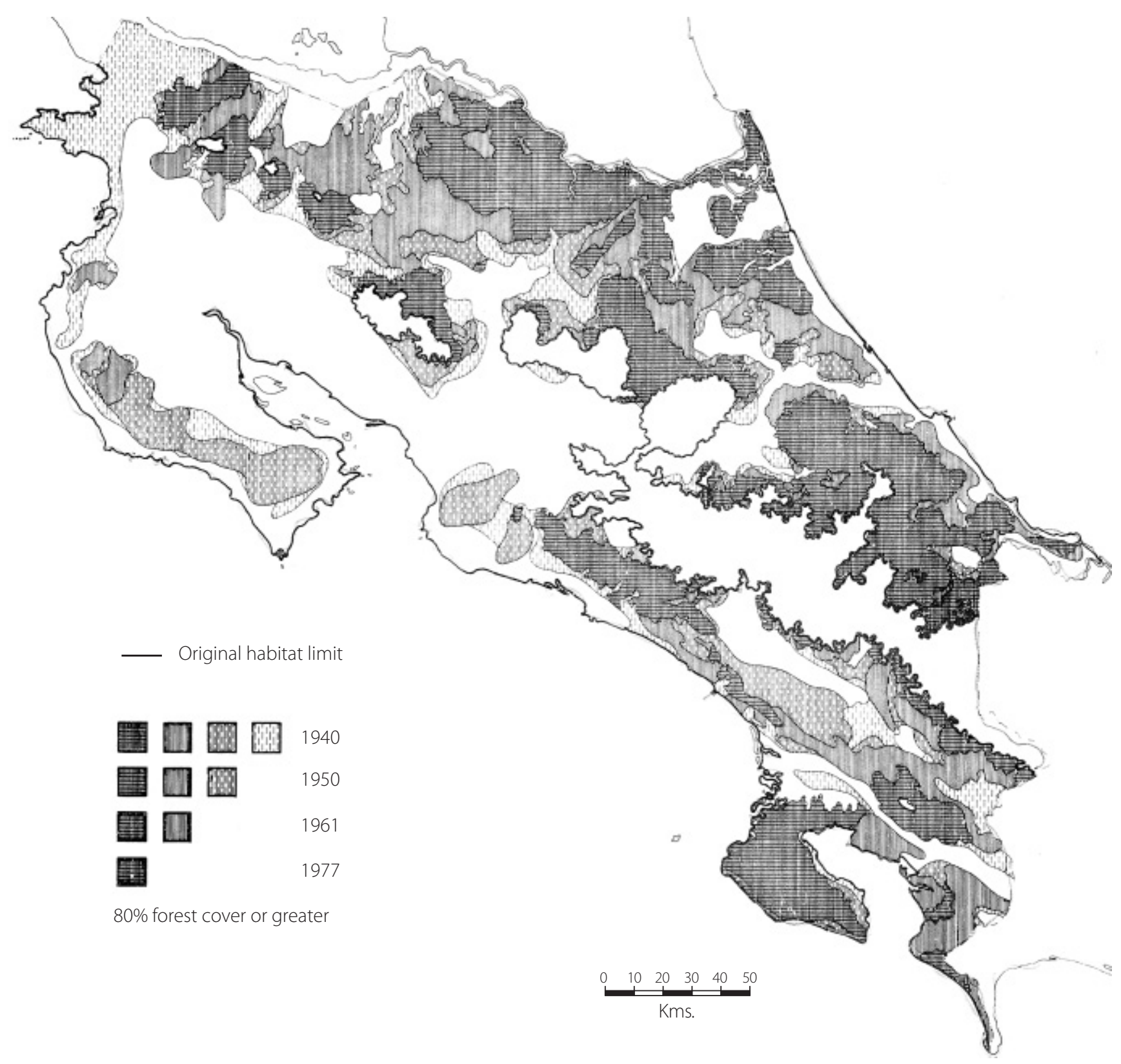

FIG. 5. Forest habitat in Costa Rica (1940-1950-1961-1977) for Eagles and Eagle-hawks, and the species Tayassu pecari, Ara macao and Harpia harpyja. 


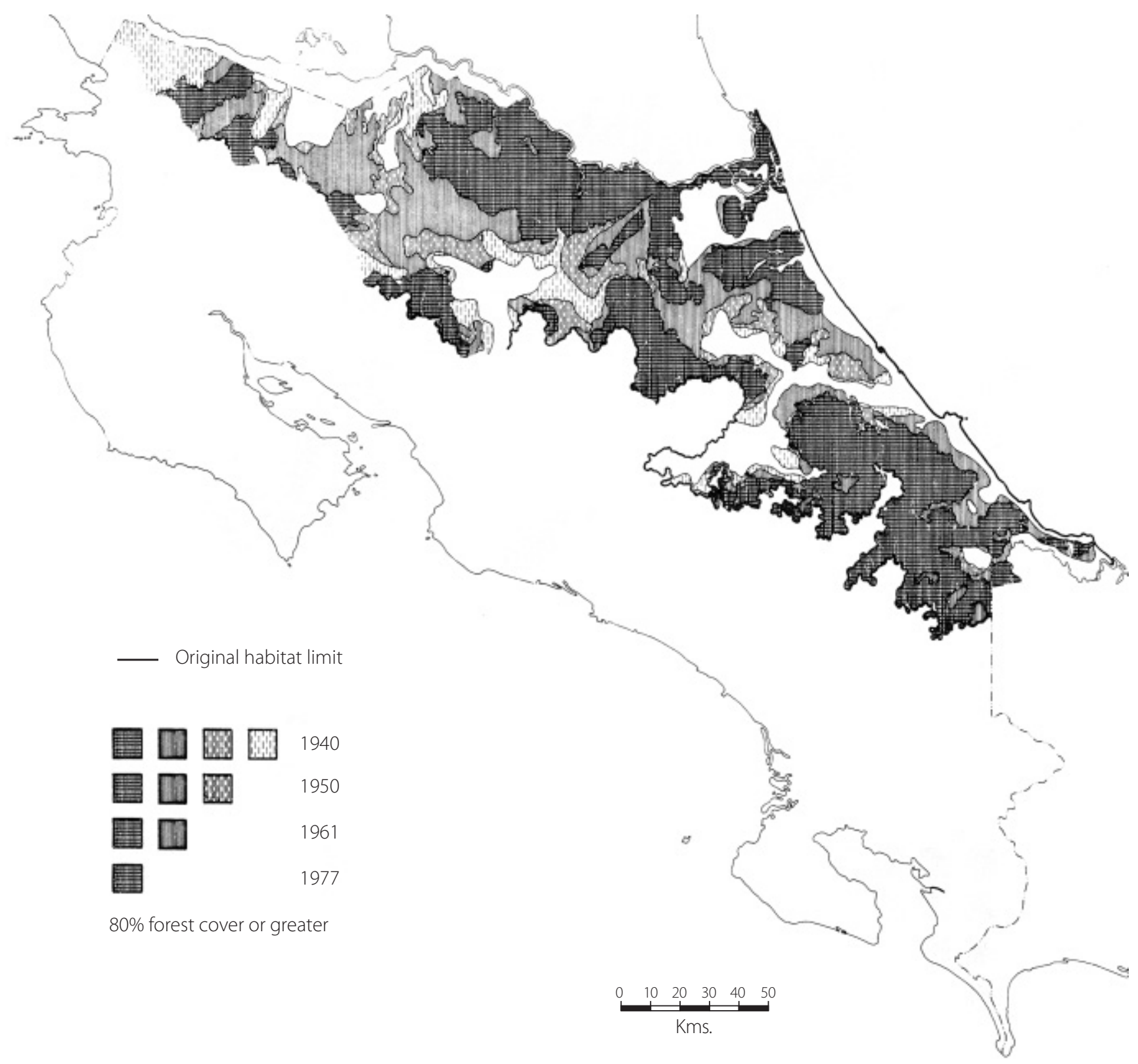

FIG. 6. Forest habitat in Costa Rica (1940-1950-1961-1977) for the species Ara ambigua. 


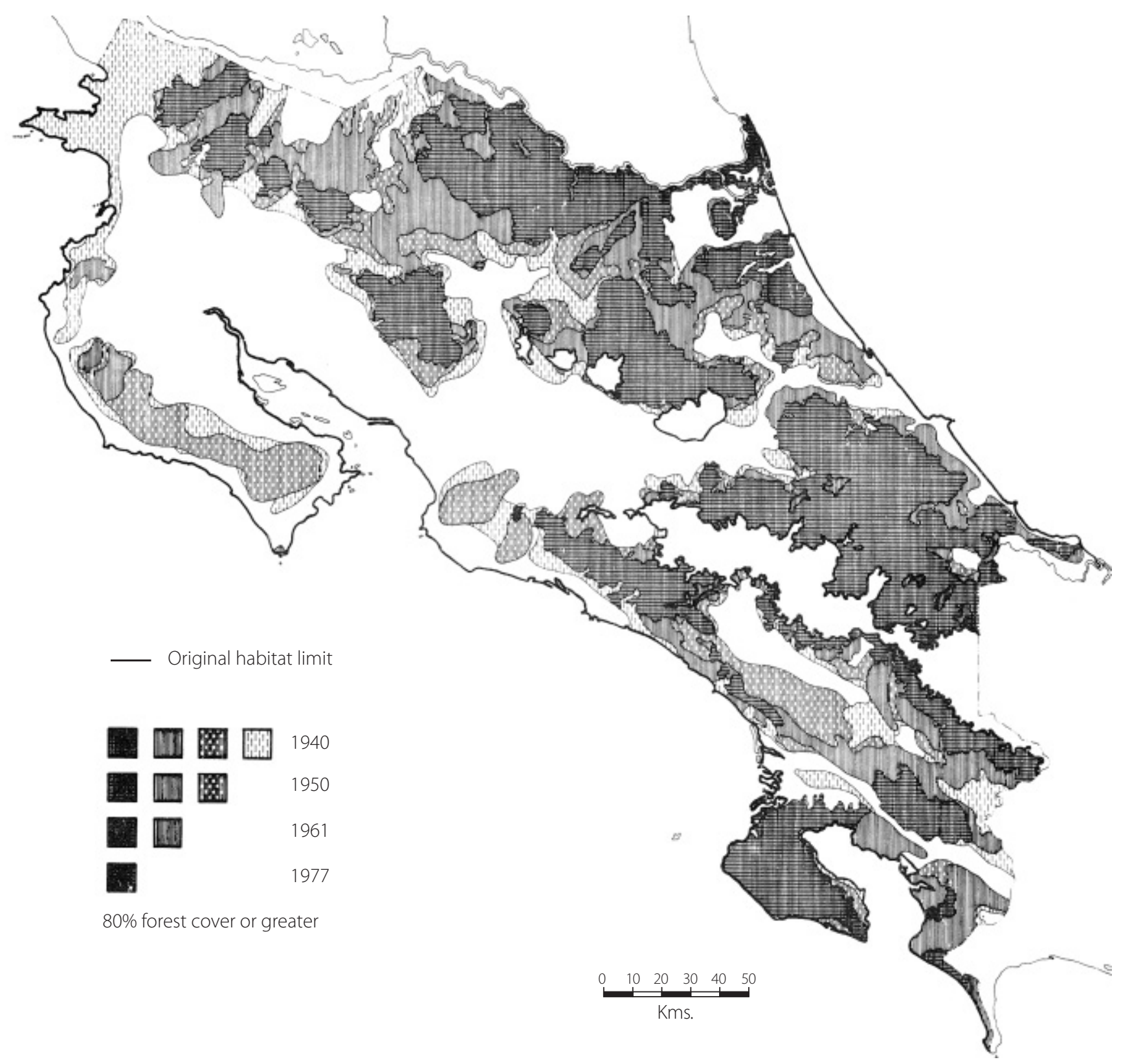

FIG. 7. Forest habitat in Costa Rica (1940-1950-1961-1977) for Eagles and Eagle-hawks, and the species Allouatta palliata, Felis yagouaroundi and Crax rubra. 


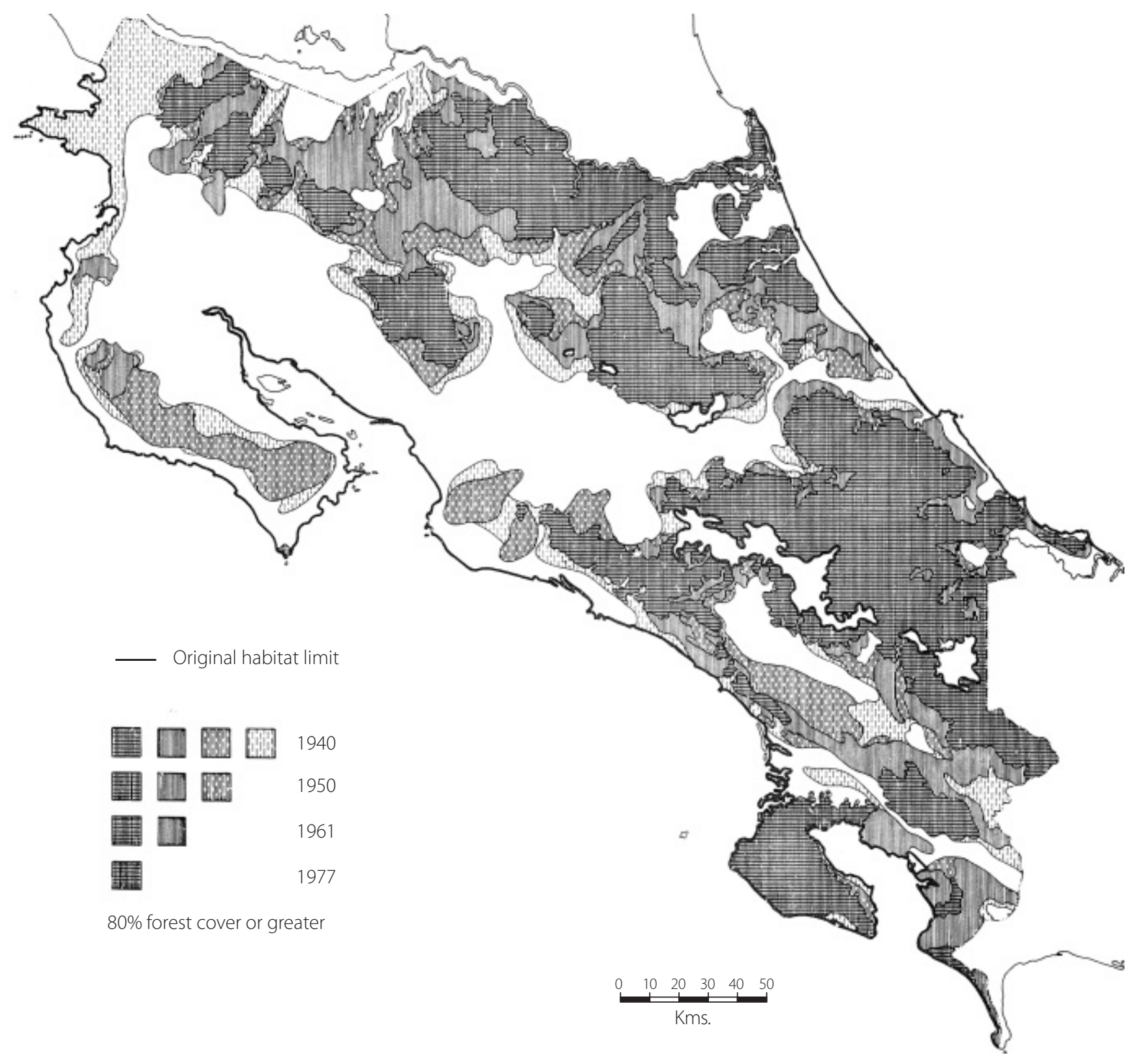

FIG. 8. Forest habitat in Costa Rica (1940-1950-1961-1977) for the species Ateles geoffroyi. 


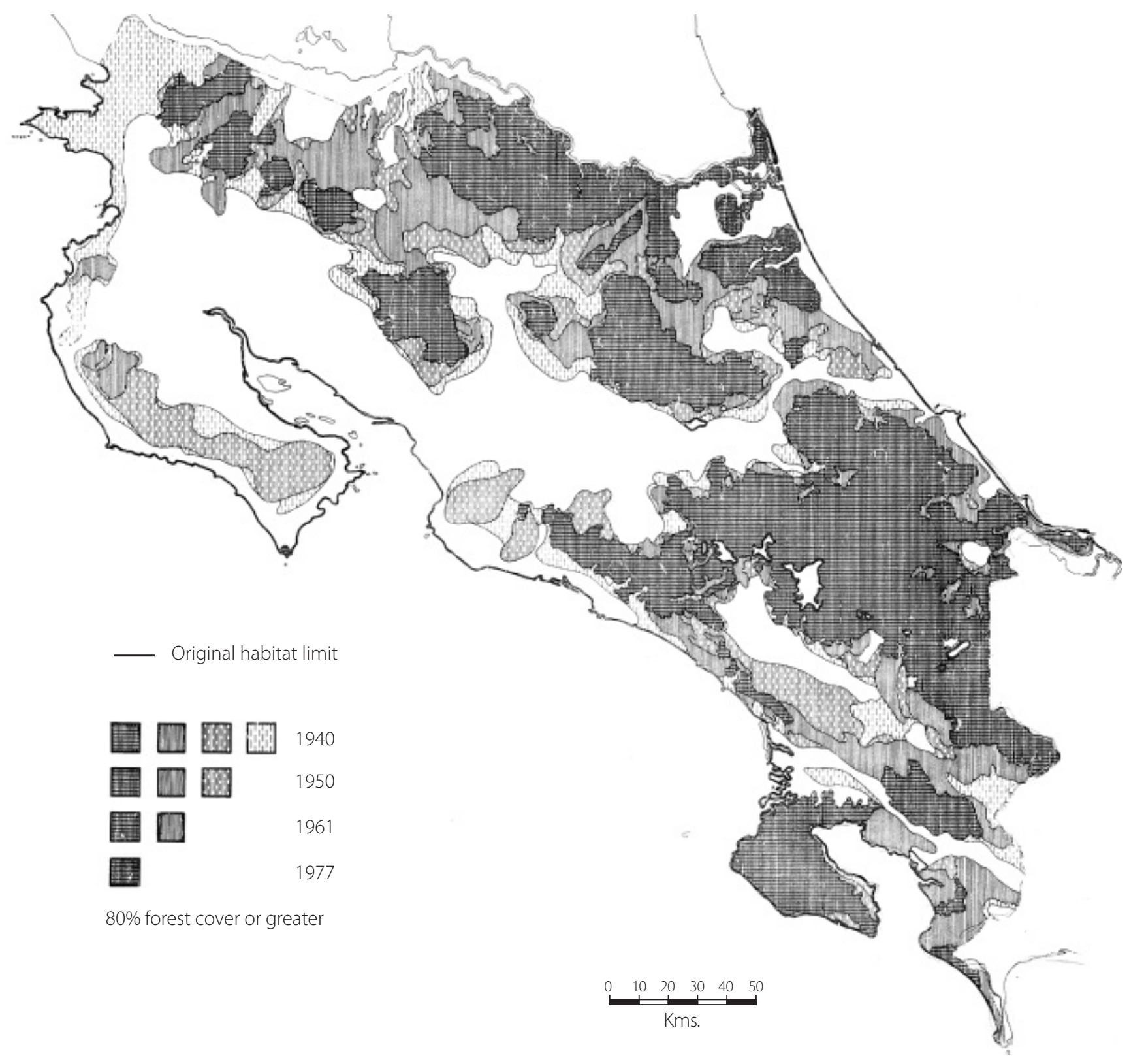

FIG. 9. Forest habitat in Costa Rica (1940-1950-1961-1977) for the species Cebus capucinus, Felis pardalis, Panthera onca, Felis concolor, Felis wiedii, Felis tigrina, Tayassu tajacu and Tapirus bairdii. 


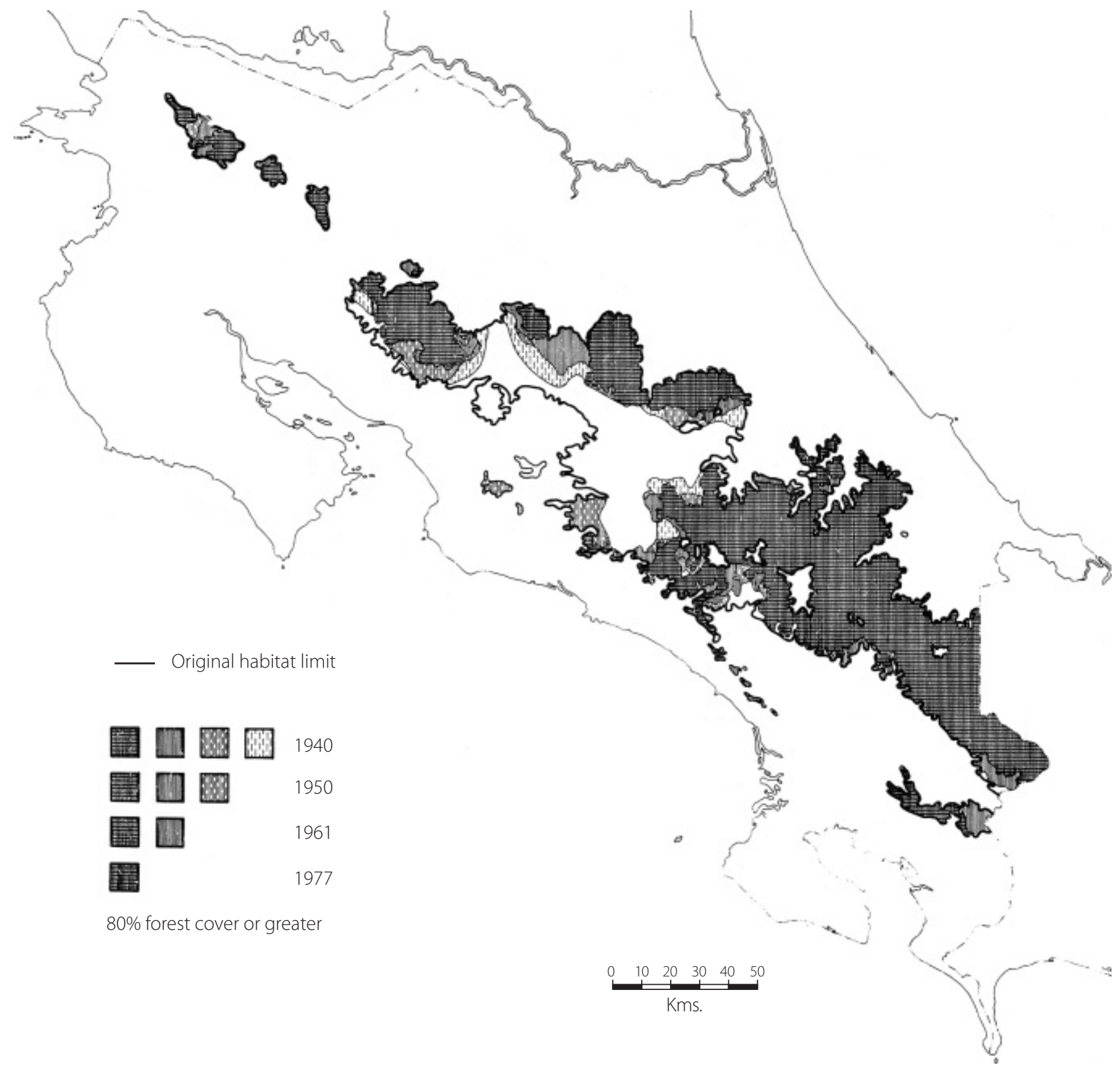

FIG. 10. Forest habitat in Costa Rica (1940-1950-1961-1977) for the species Pharomachrus moccino. 


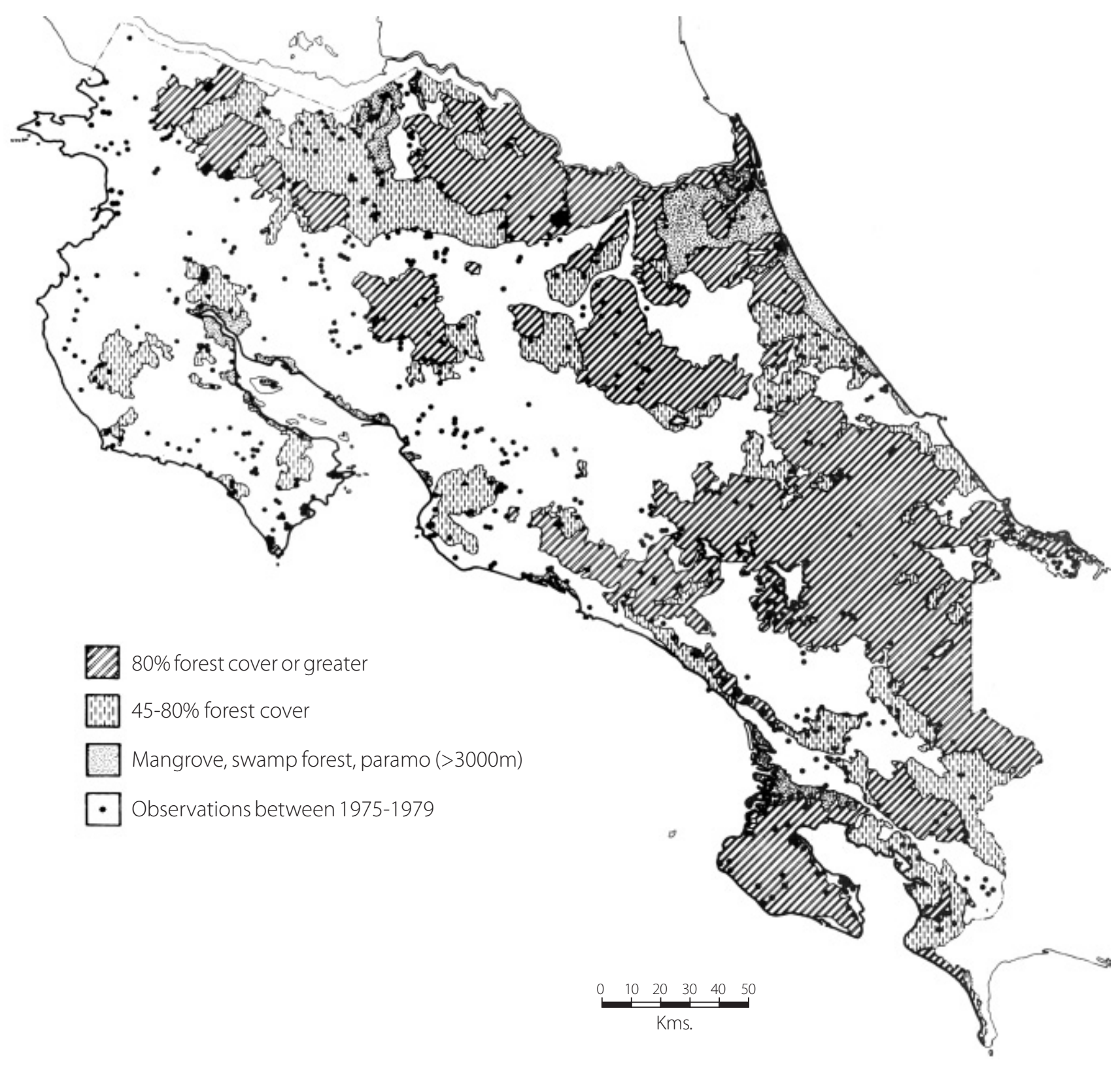

FIG. 11. Forest habitat in Costa Rica (1977) for the species Cebus capucinus. 


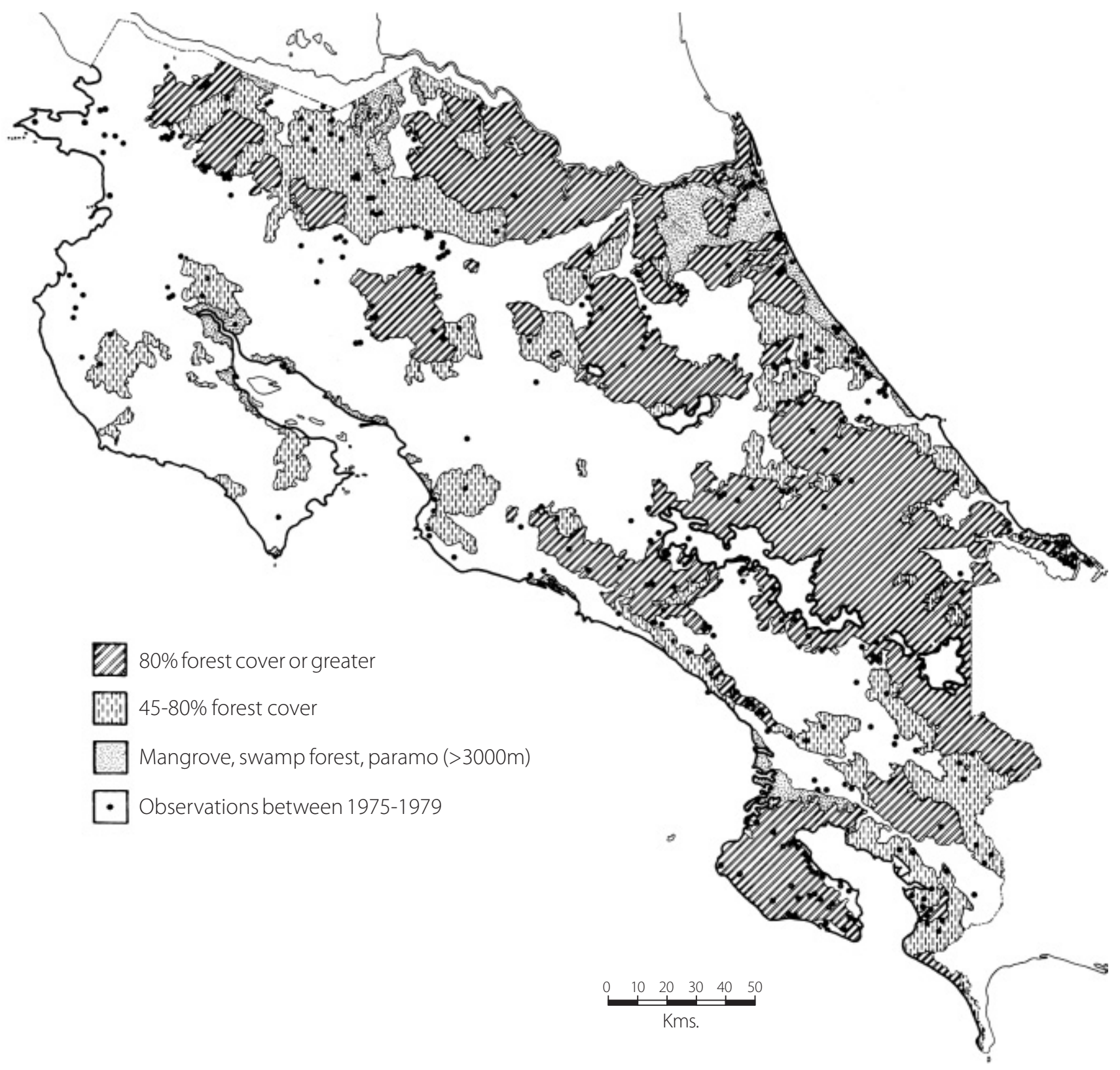

FIG. 12. Forest habitat in Costa Rica (1977) for the species Ateles geoffroyi. 


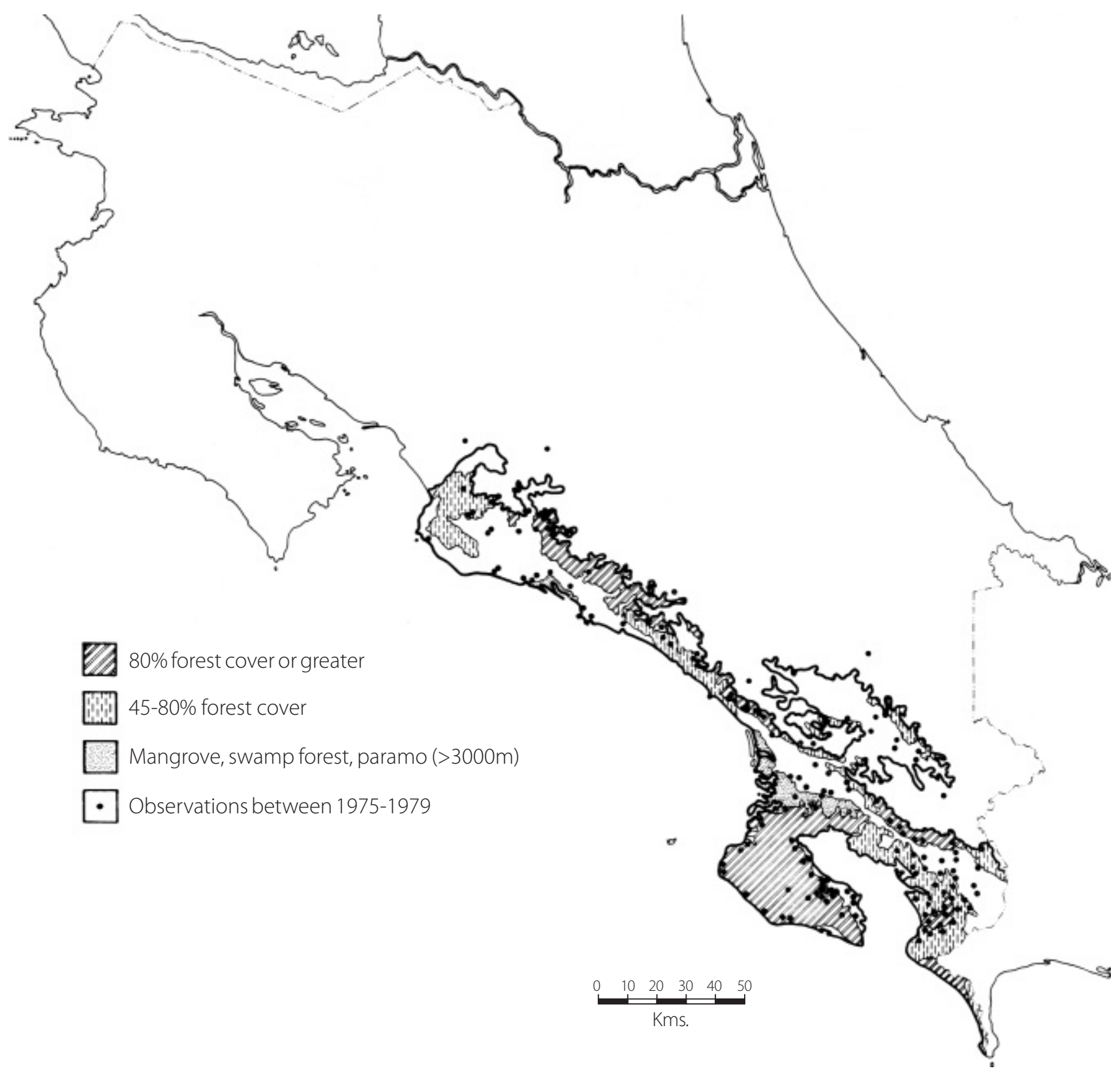

FIG. 13. Forest habitat in Costa Rica (1977) for the species Saimiri oerstedii. 


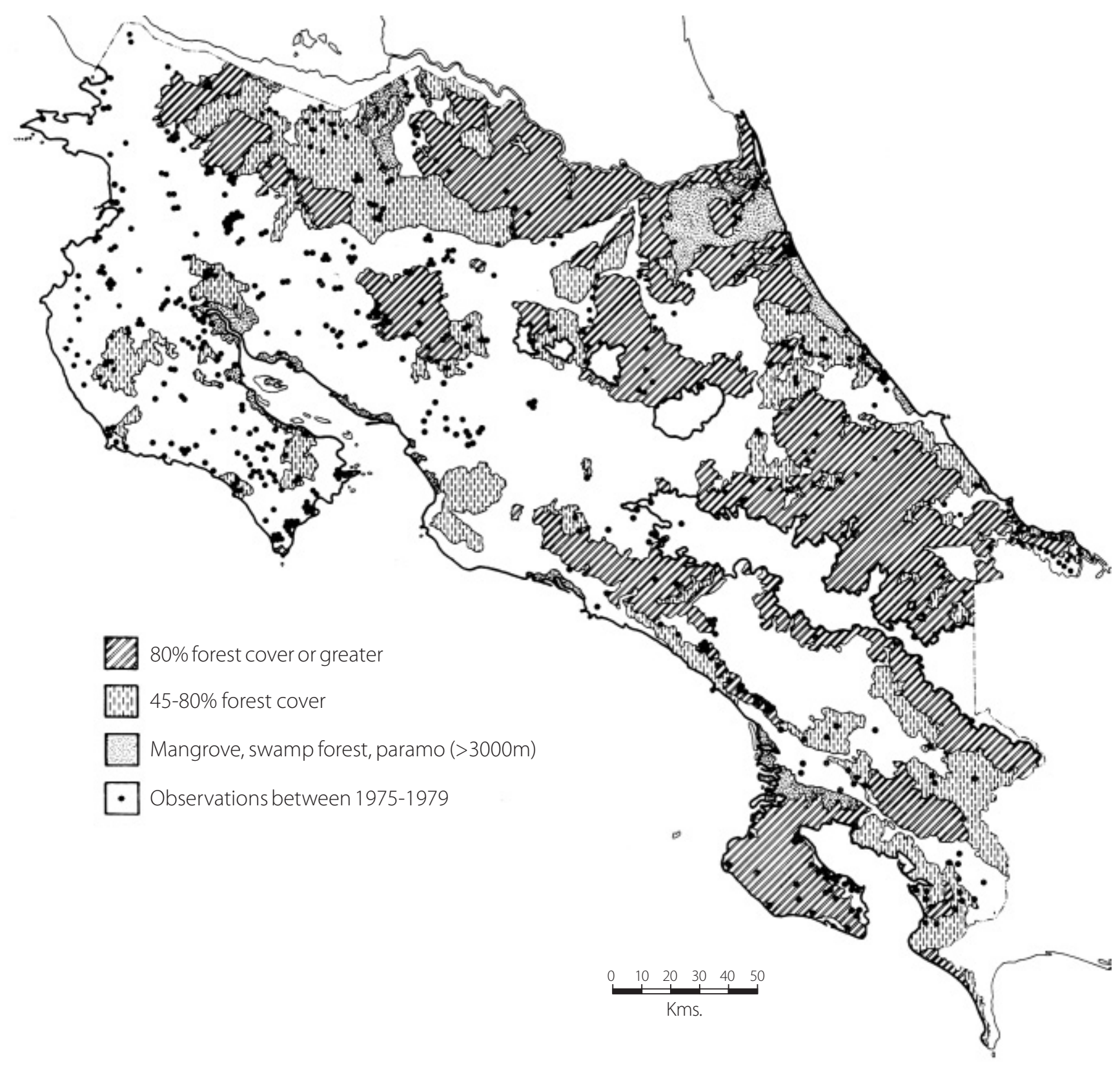

FIG. 14. Forest habitat in Costa Rica (1977) for the species Alouatta palliata. 


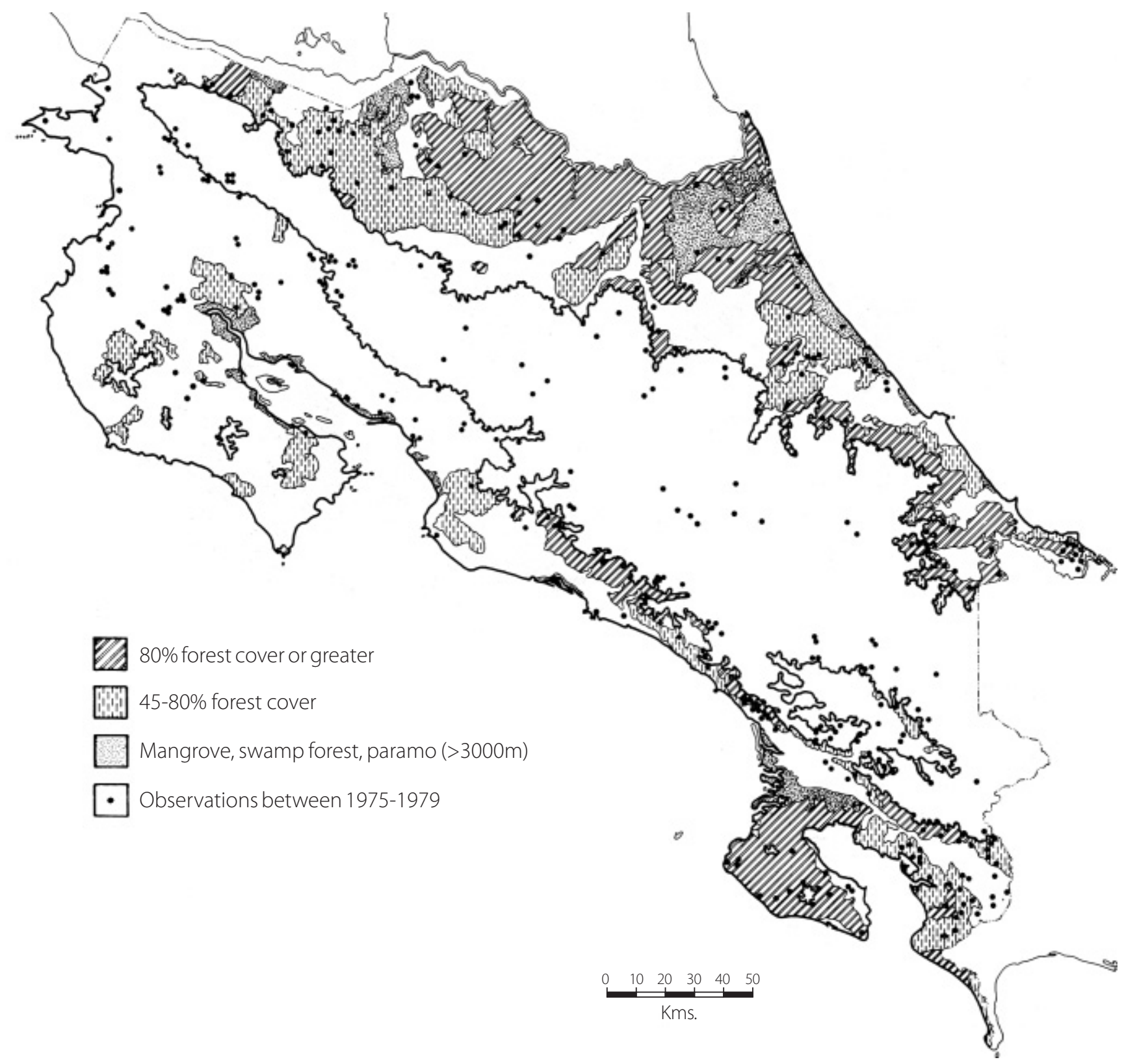

FIG. 15. Forest habitat in Costa Rica (1977) for the species Myrmecophaga tridactyla. 


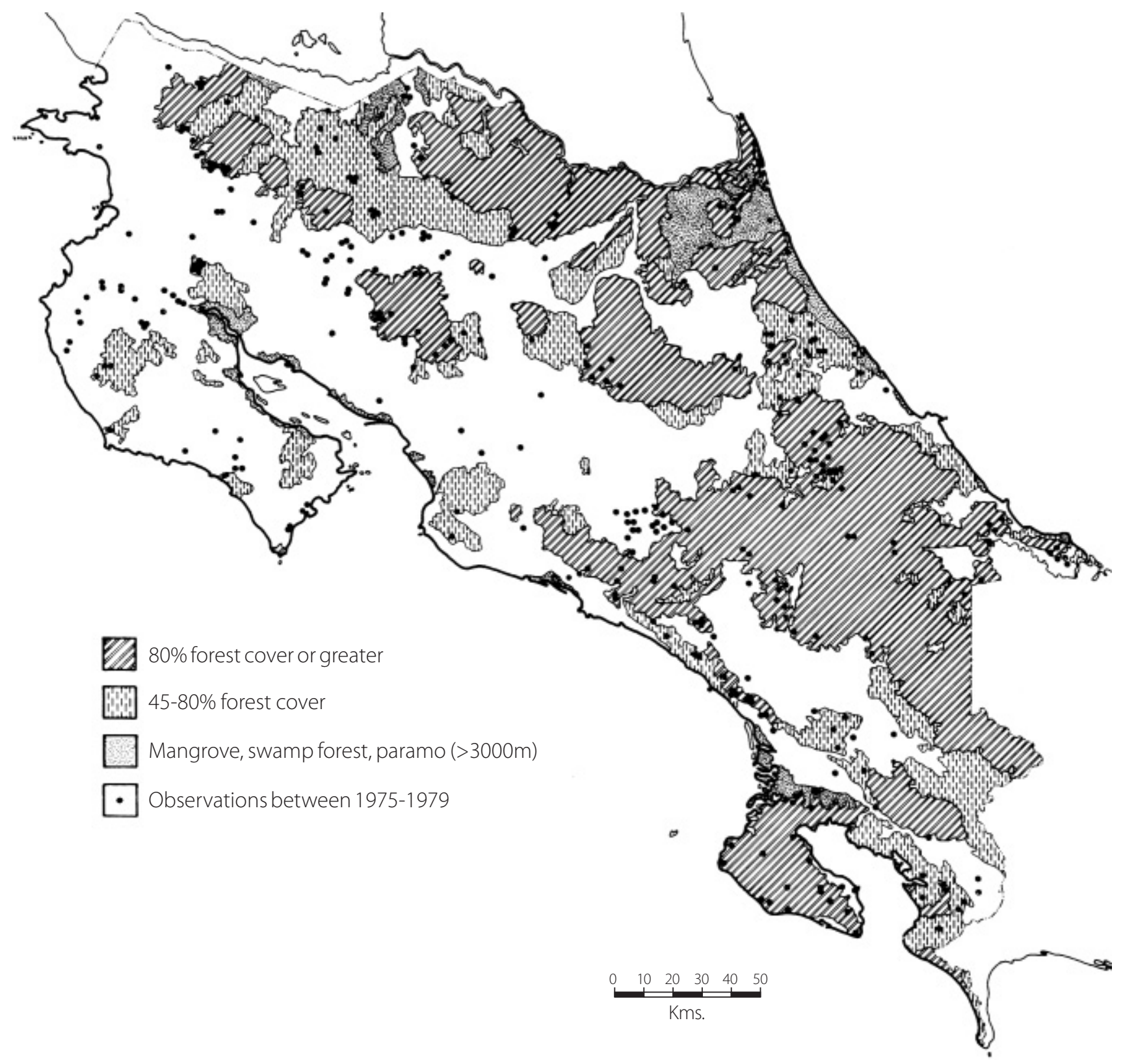

FIG. 16. Forest habitat in Costa Rica (1977) for the species Felis concolor. 


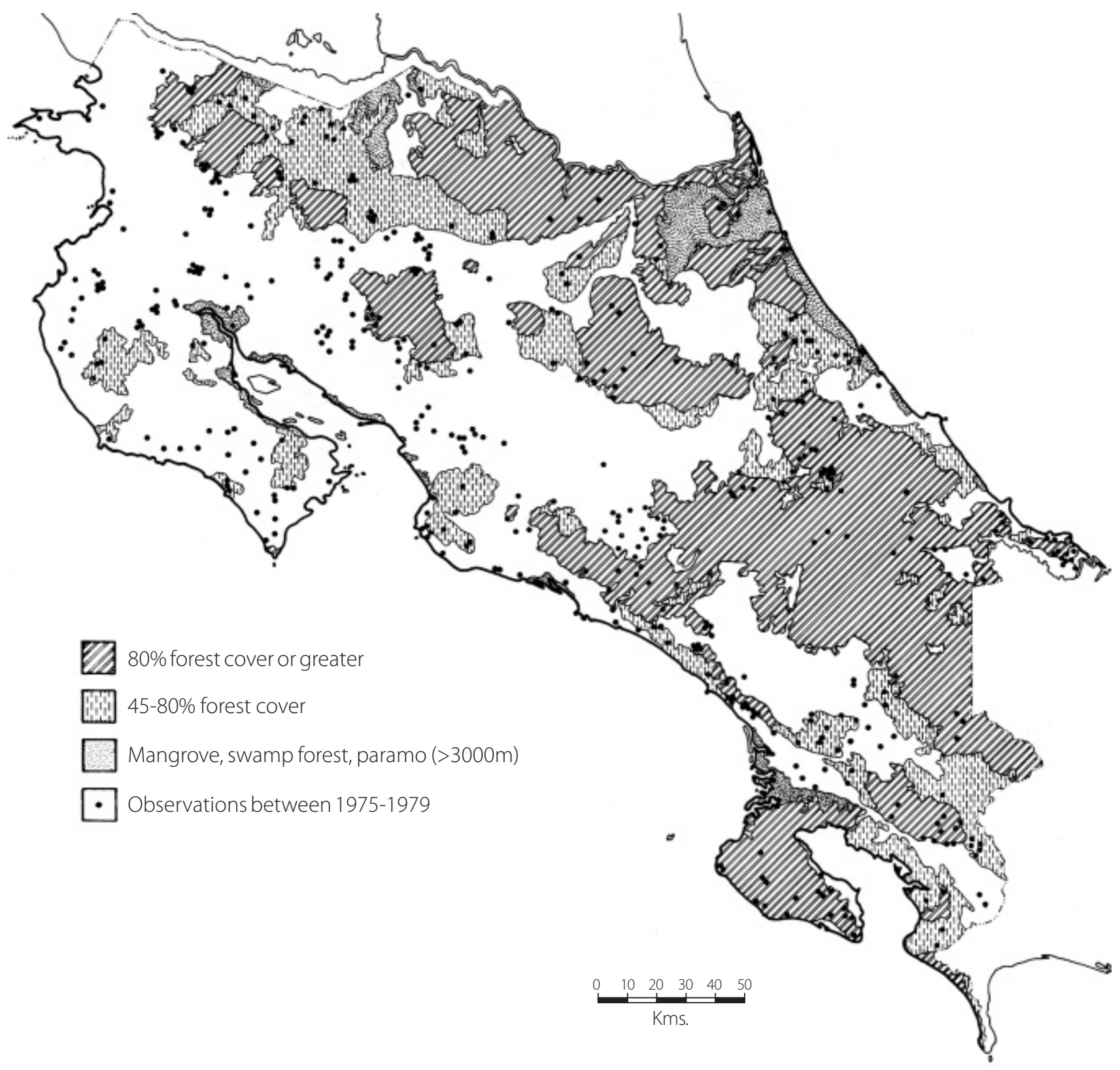

FIG. 17. Forest habitat in Costa Rica (1977) for the species Felis pardalis. 


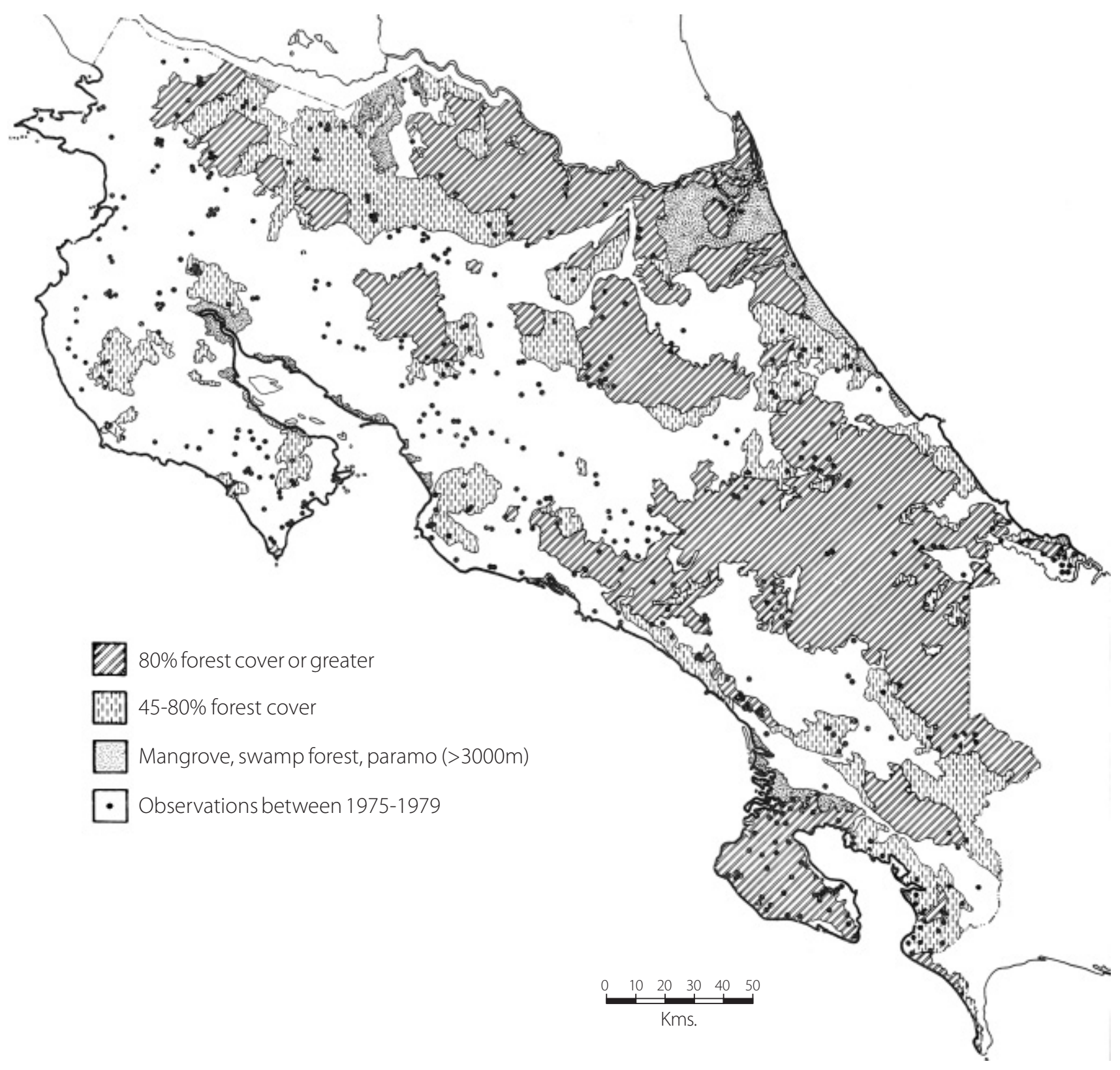

FIG. 18. Forest habitat in Costa Rica (1977) for the species Felis wiedii and Felis tigrina. 


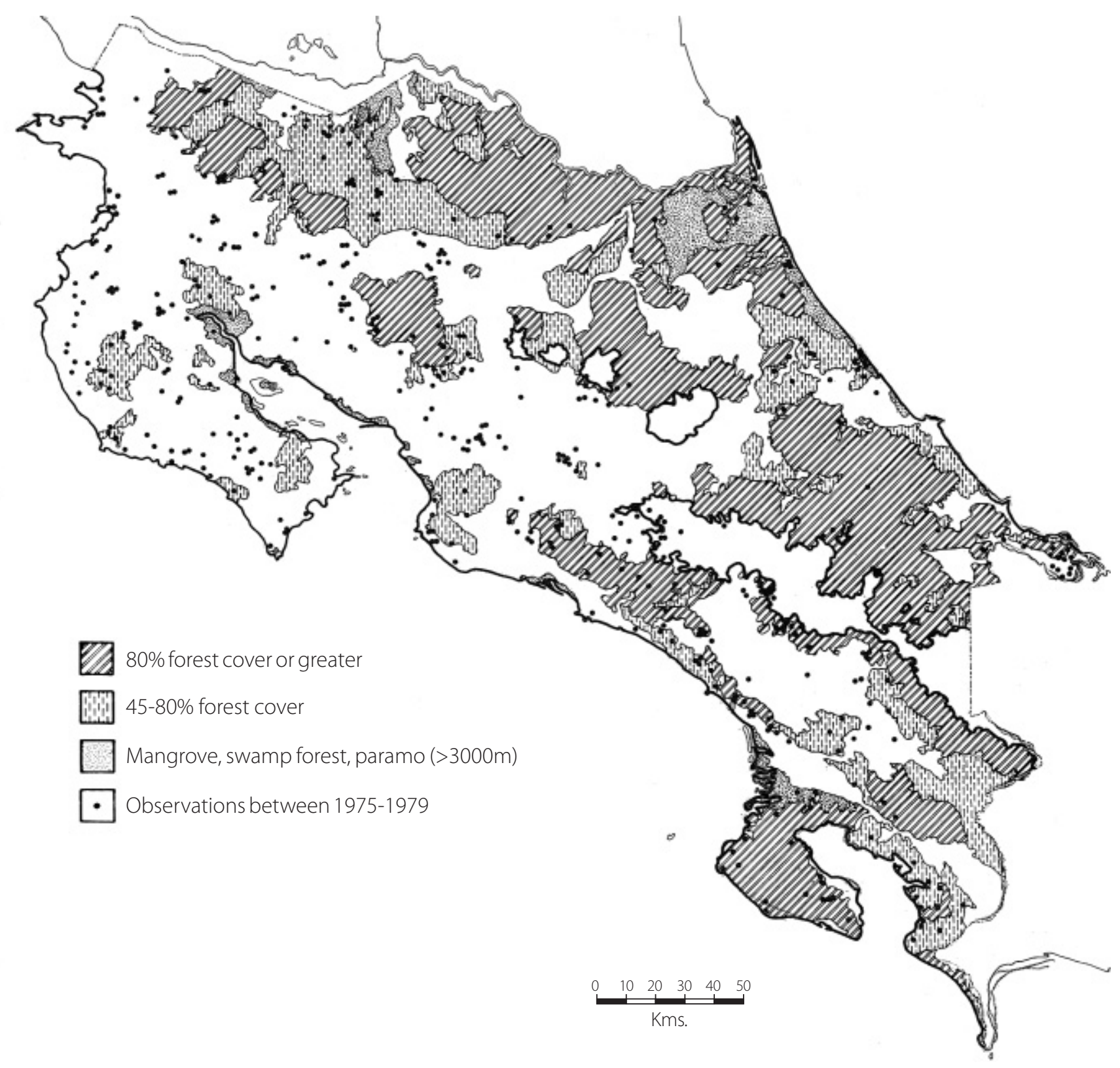

FIG. 19. Forest habitat in Costa Rica (1977) for the species Felis yagouaroundi. 


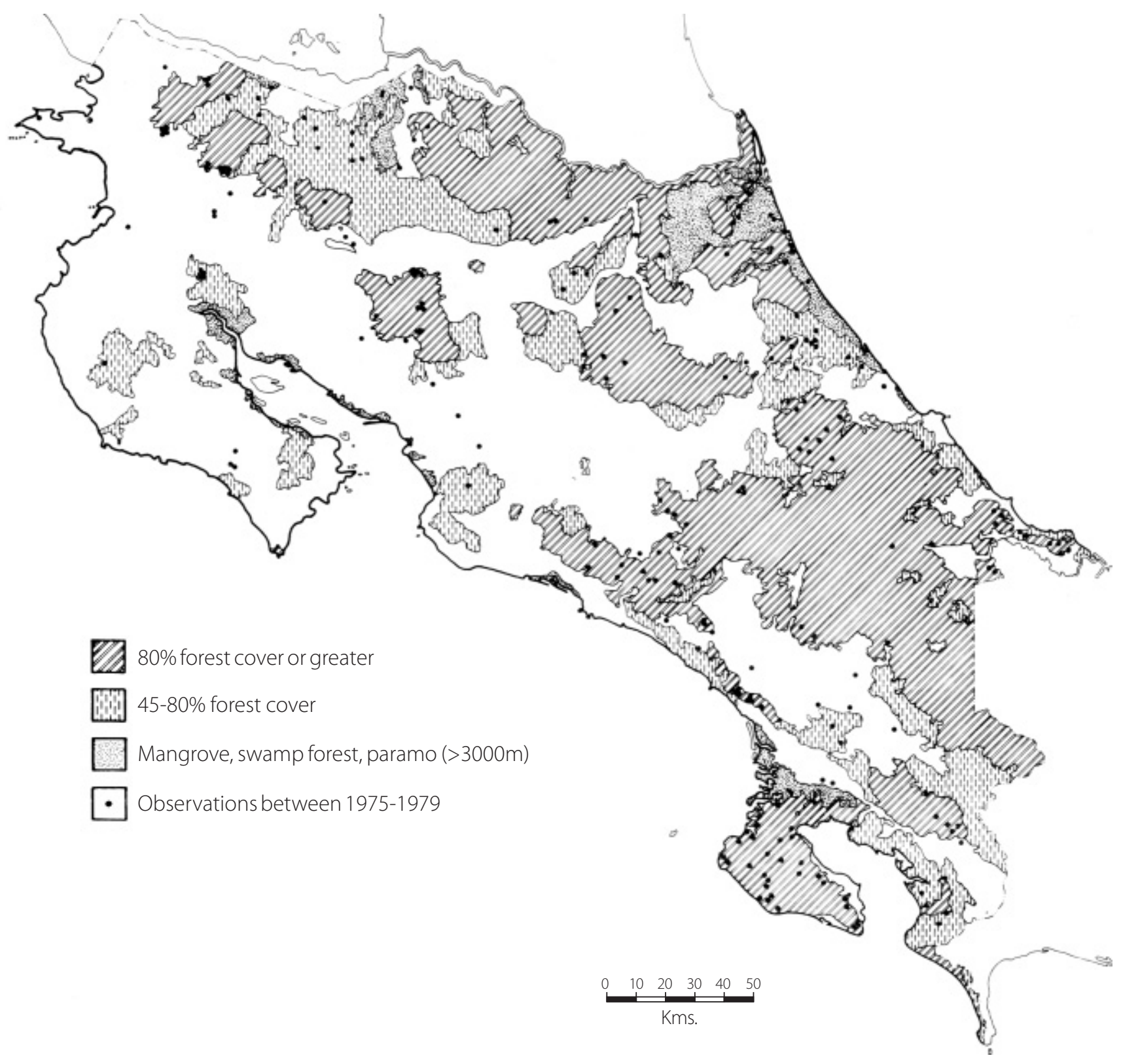

FIG. 20. Forest habitat in Costa Rica (1977) for the species Panthera onca. 


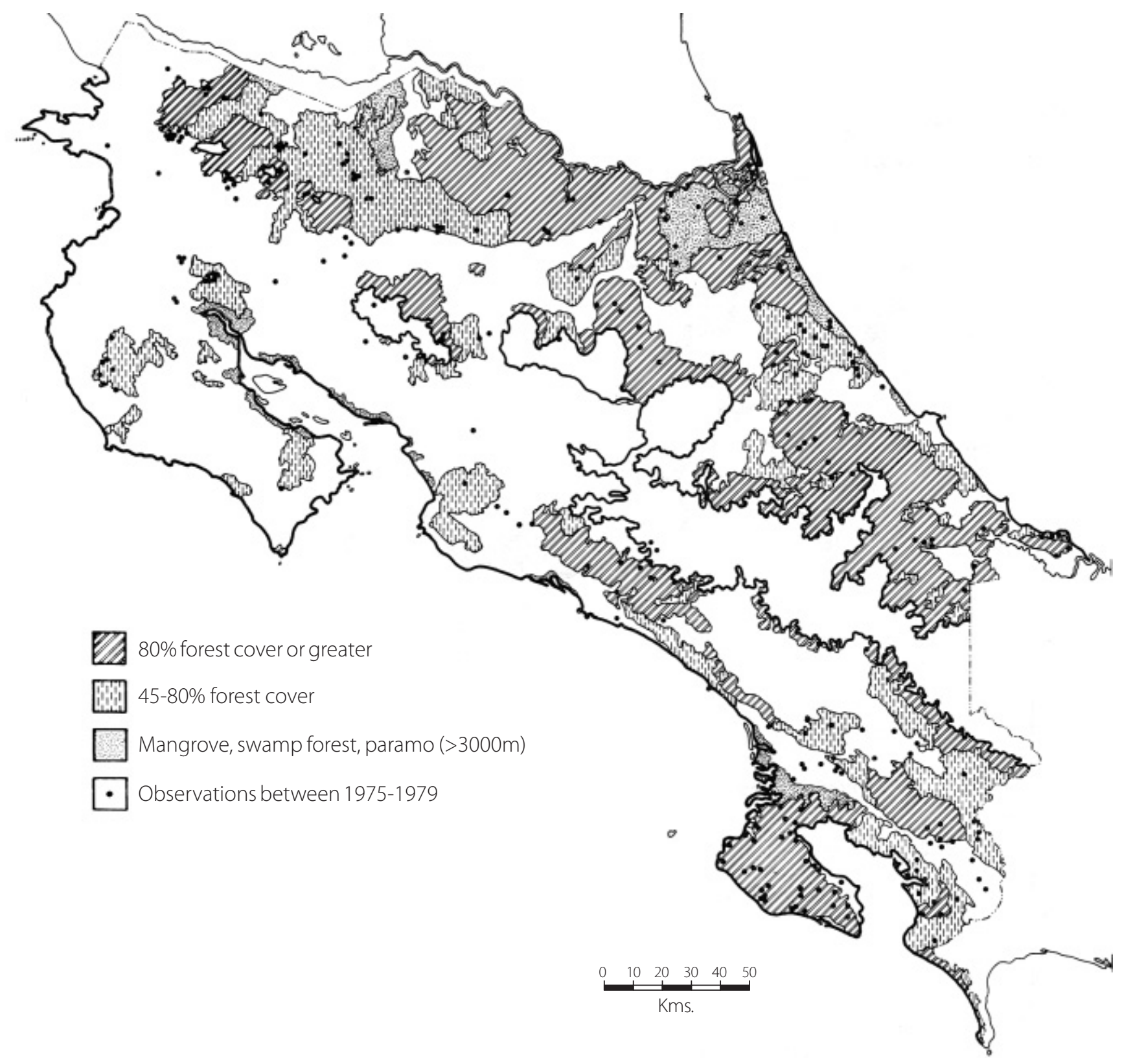

FIG. 21. Forest habitat in Costa Rica (1977) for the species Tayassu pecari. 


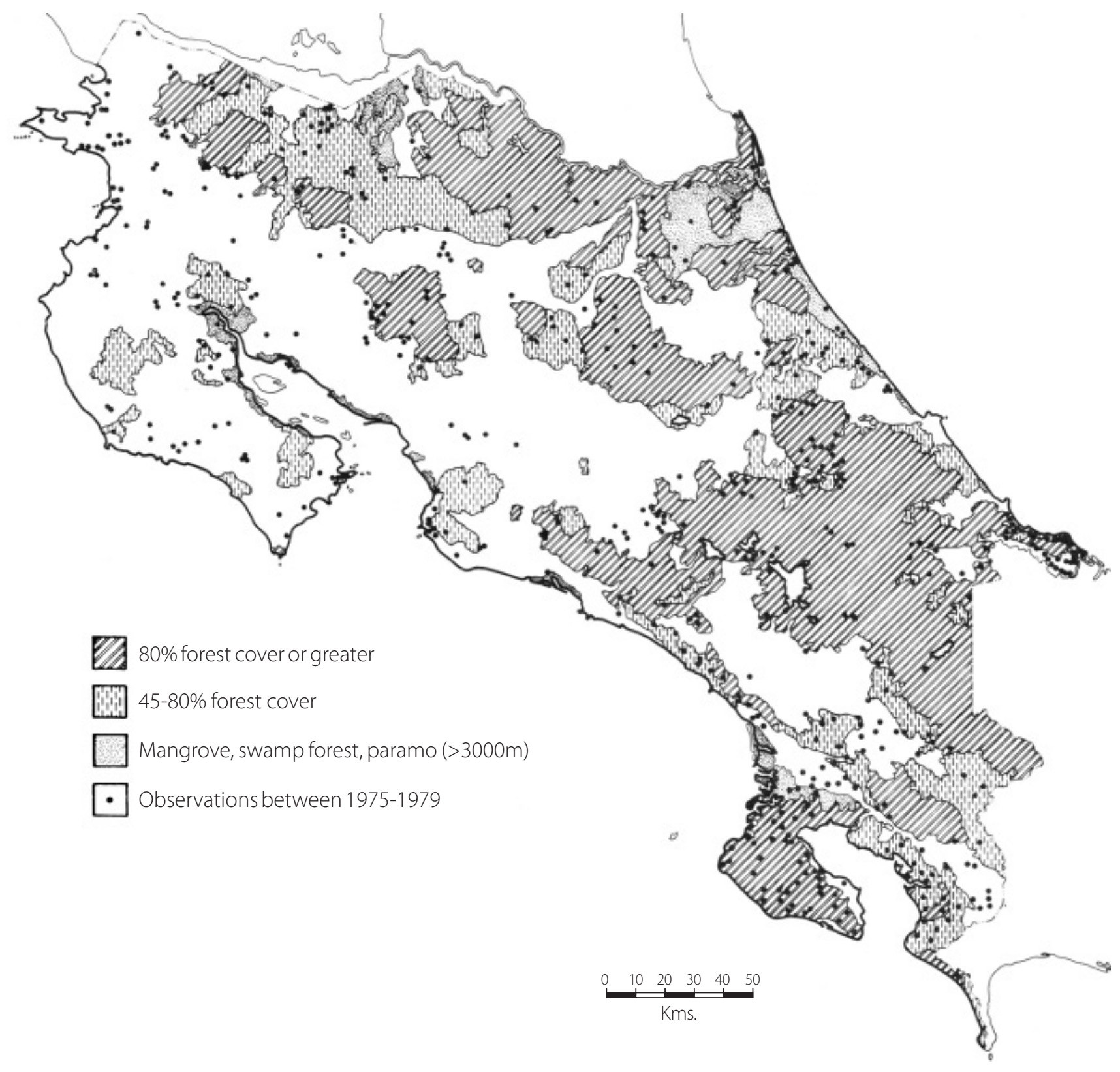

FIG. 22. Forest habitat in Costa Rica (1977) for the species Tayassu tajacu. 


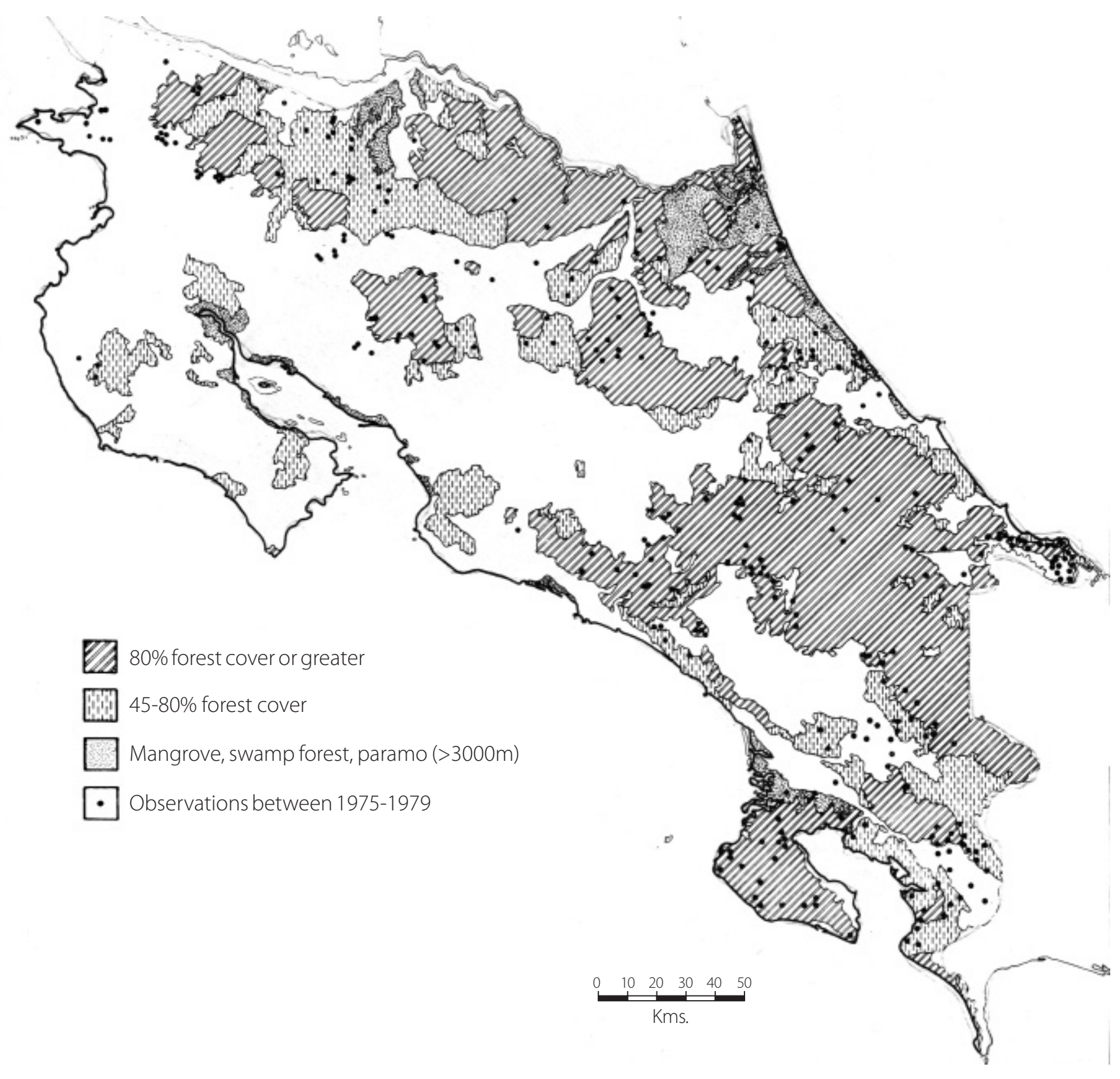

FIG. 23. Forest habitat in Costa Rica (1977) for the species Tapirus bairdii. 


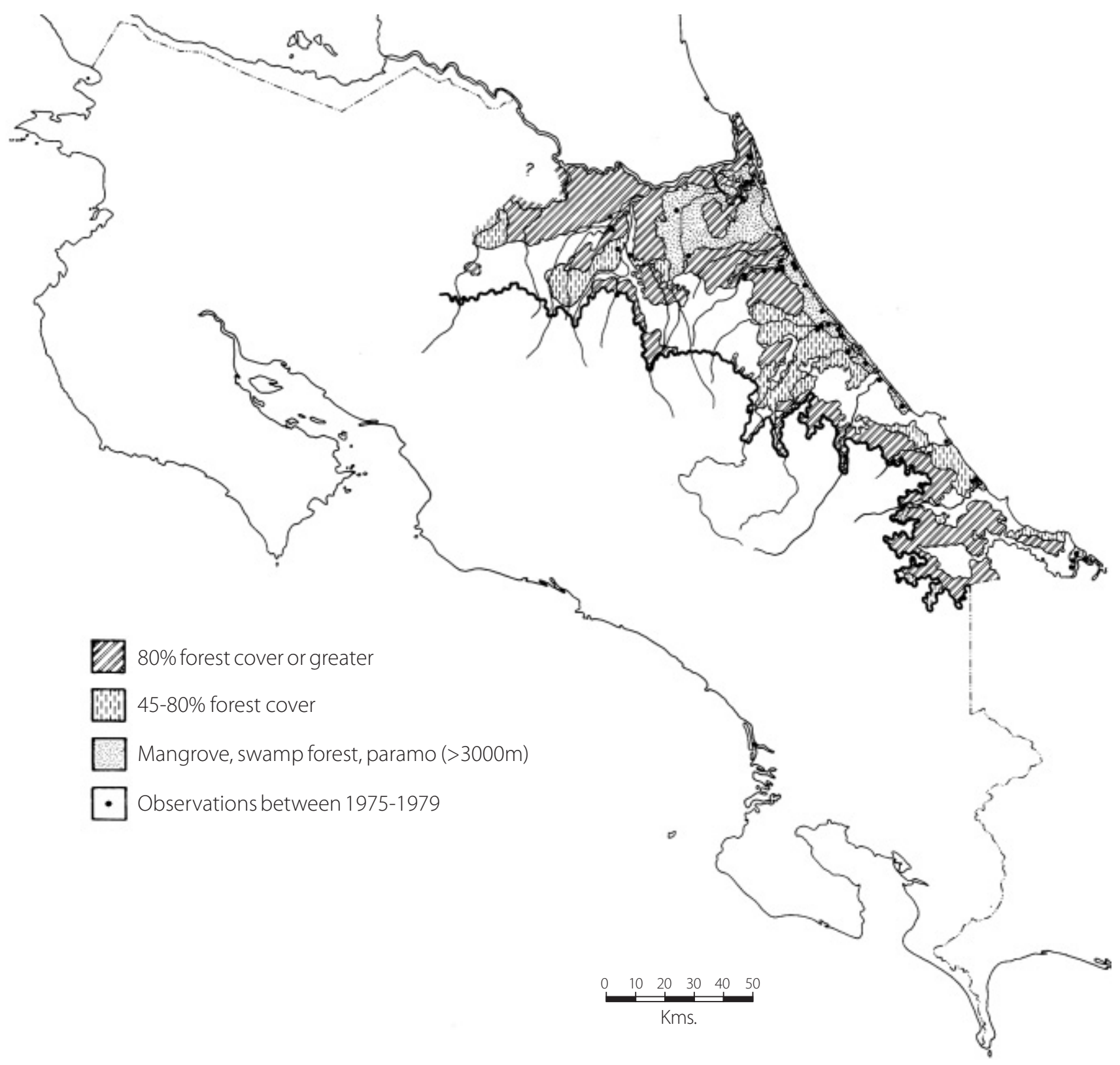

FIG. 24. Forest habitat in Costa Rica (1977) for the species Trichechus manatus. 


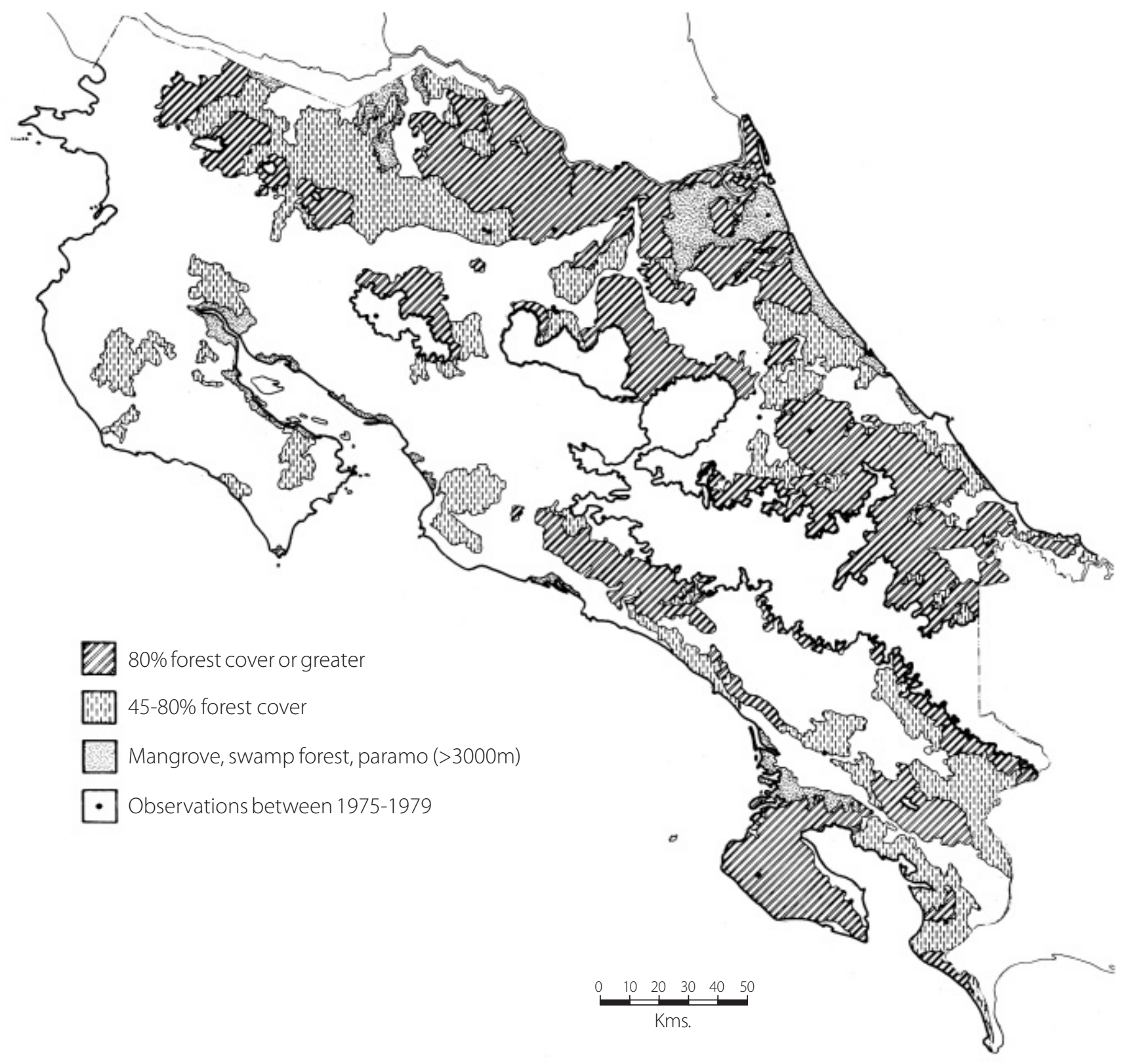

FIG. 25. Forest habitat in Costa Rica (1977) for the species Harpia harpyja. 


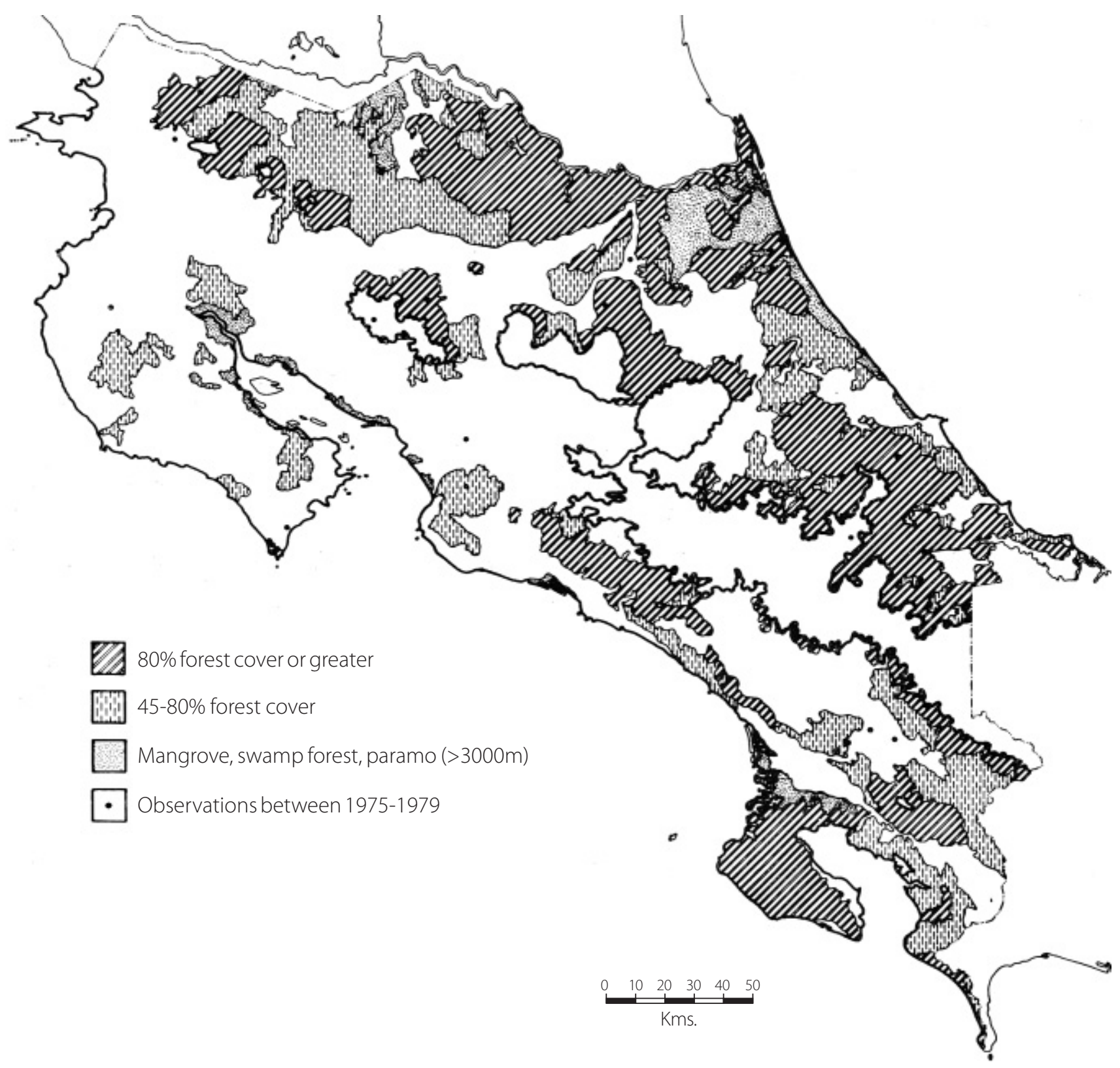

FIG. 26. Forest habitat in Costa Rica (1977) for Eagles and Hawk-eagles. 


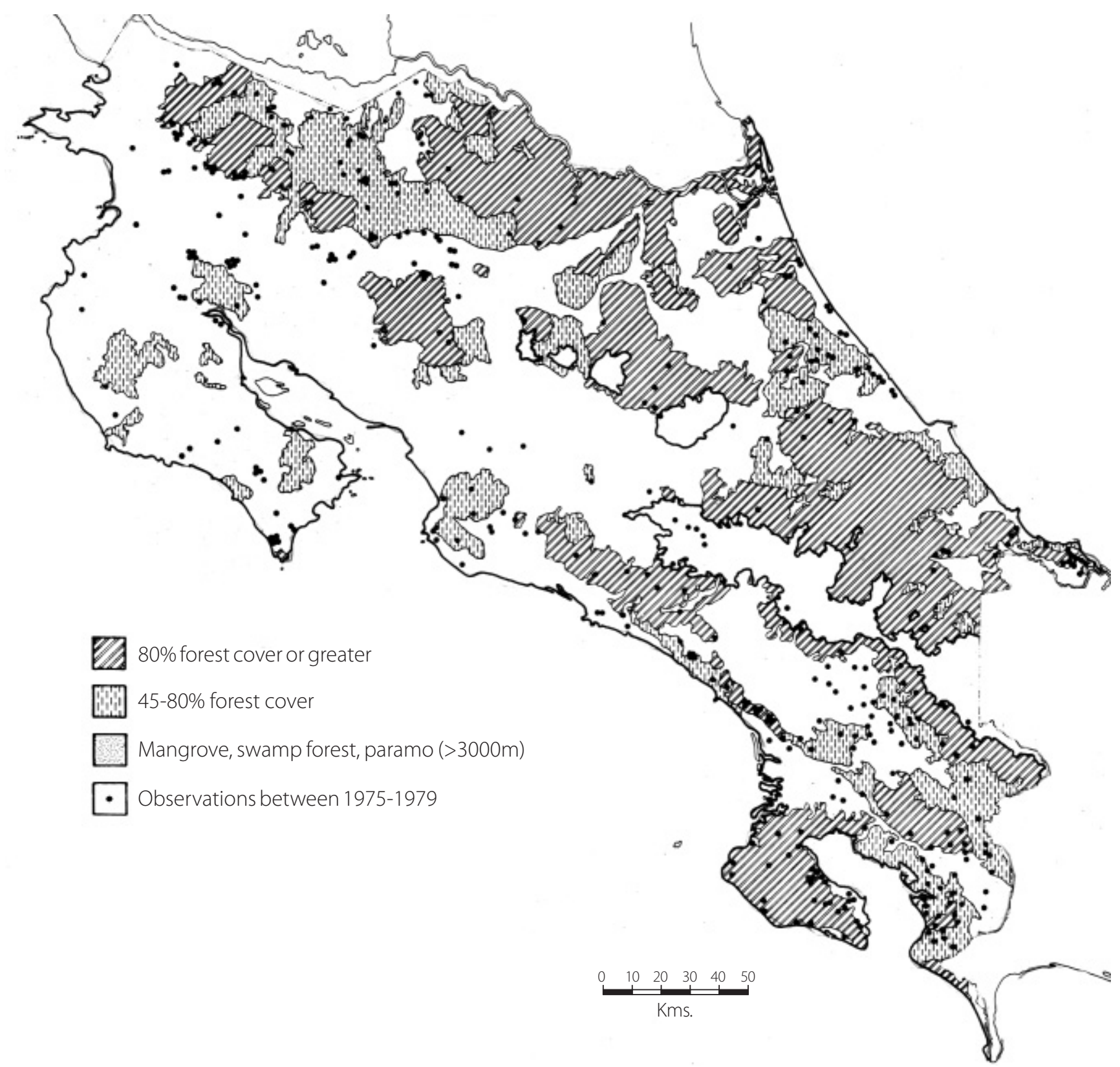

FIG. 27. Forest habitat in Costa Rica (1977) for the species Crax rubra. 


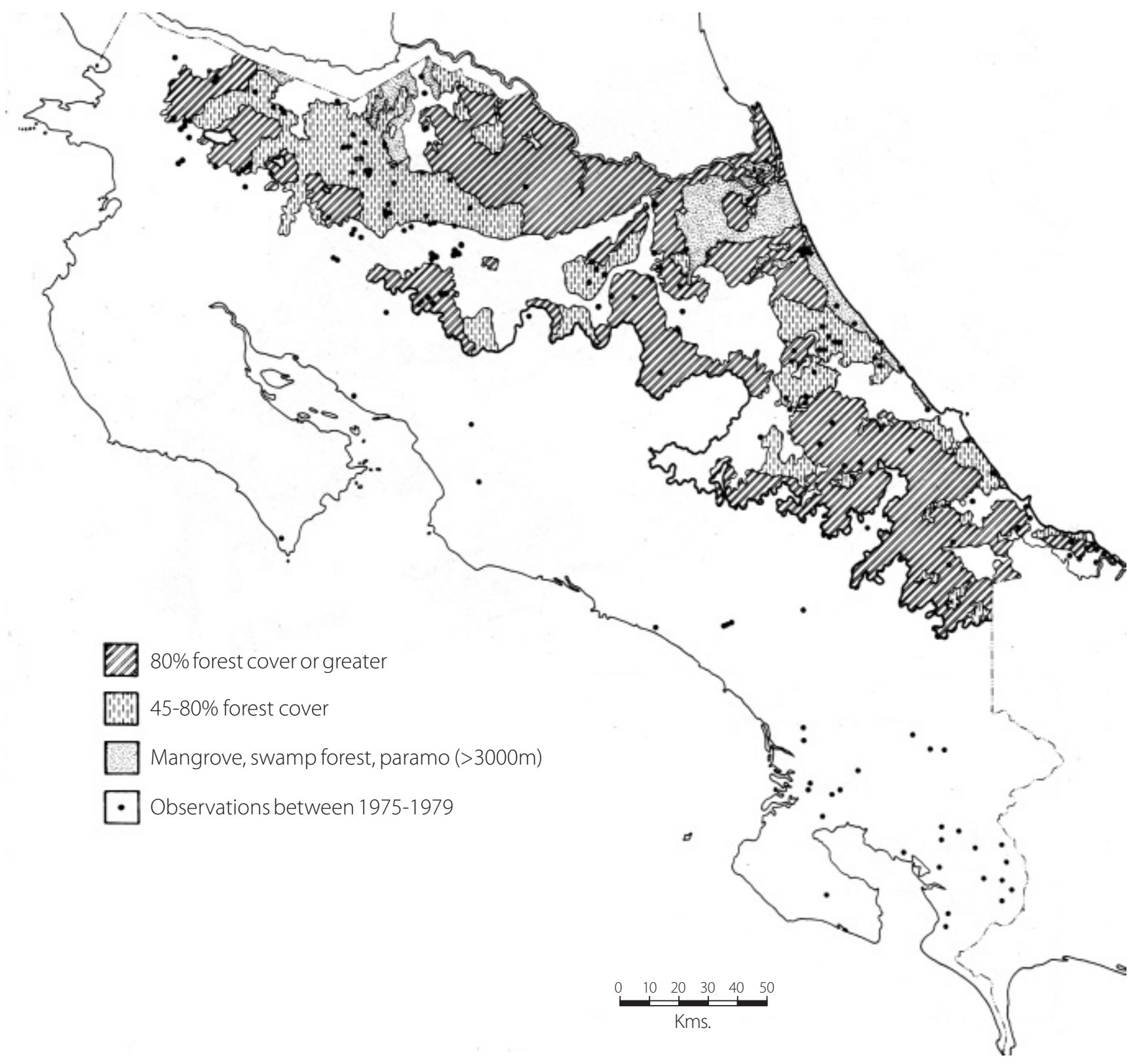

FIG. 28. Forest habitat in Costa Rica (1977) for the species Ara ambigua. 


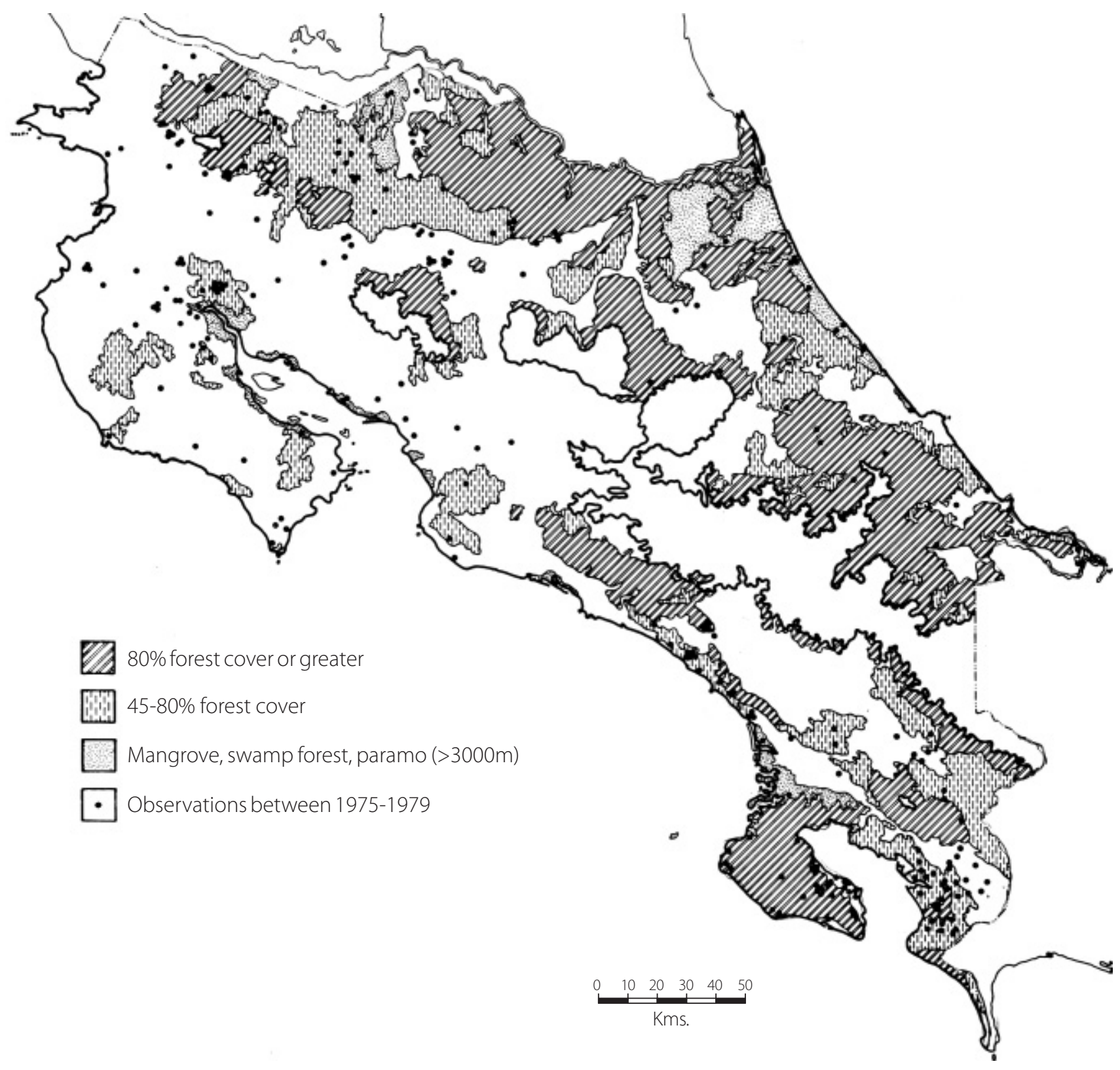

FIG. 29. Forest habitat in Costa Rica (1977) for the species Ara macao. 


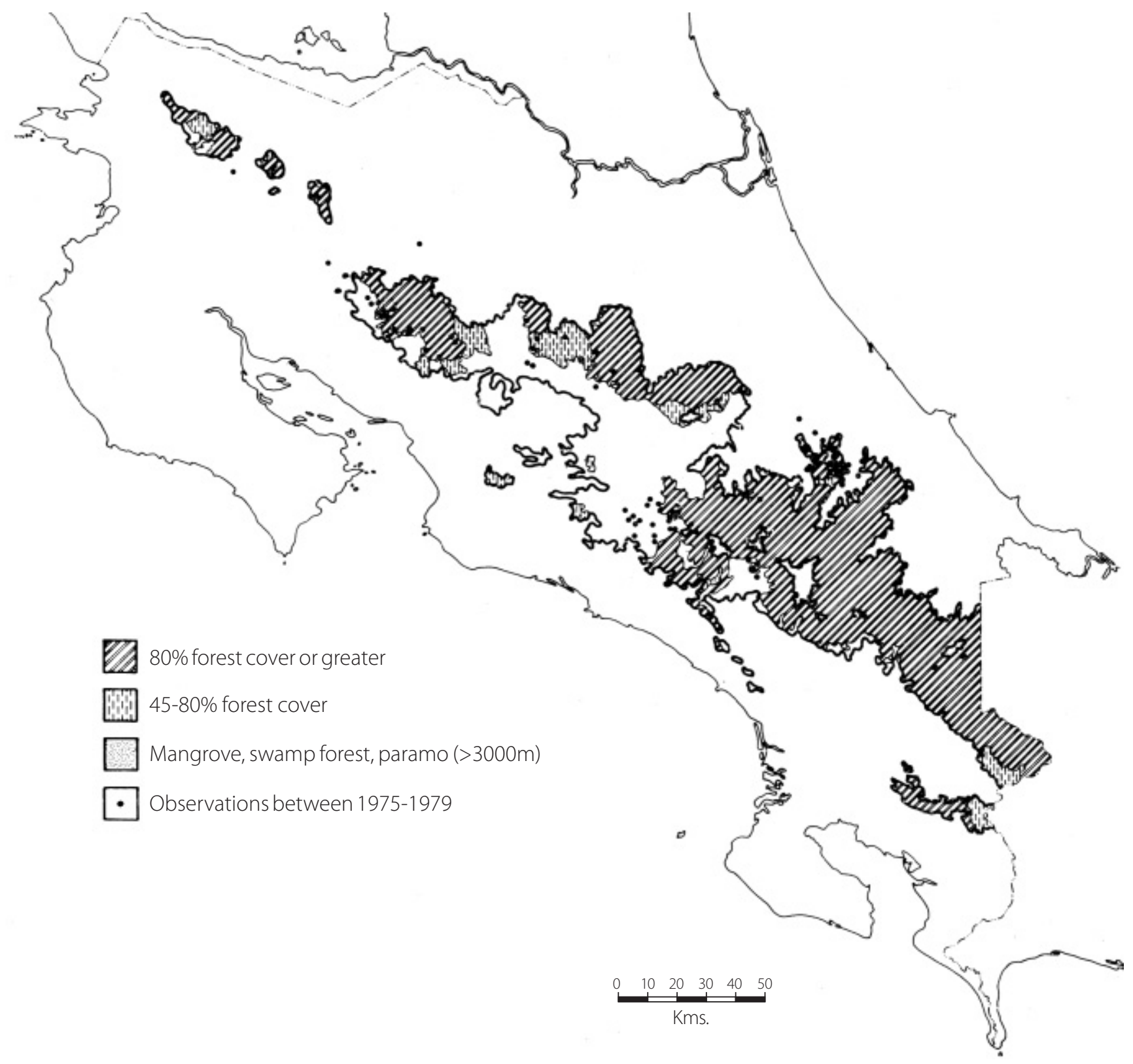

FIG. 30. Forest habitat in Costa Rica (1977) for the species Pharomachus mocinno. 


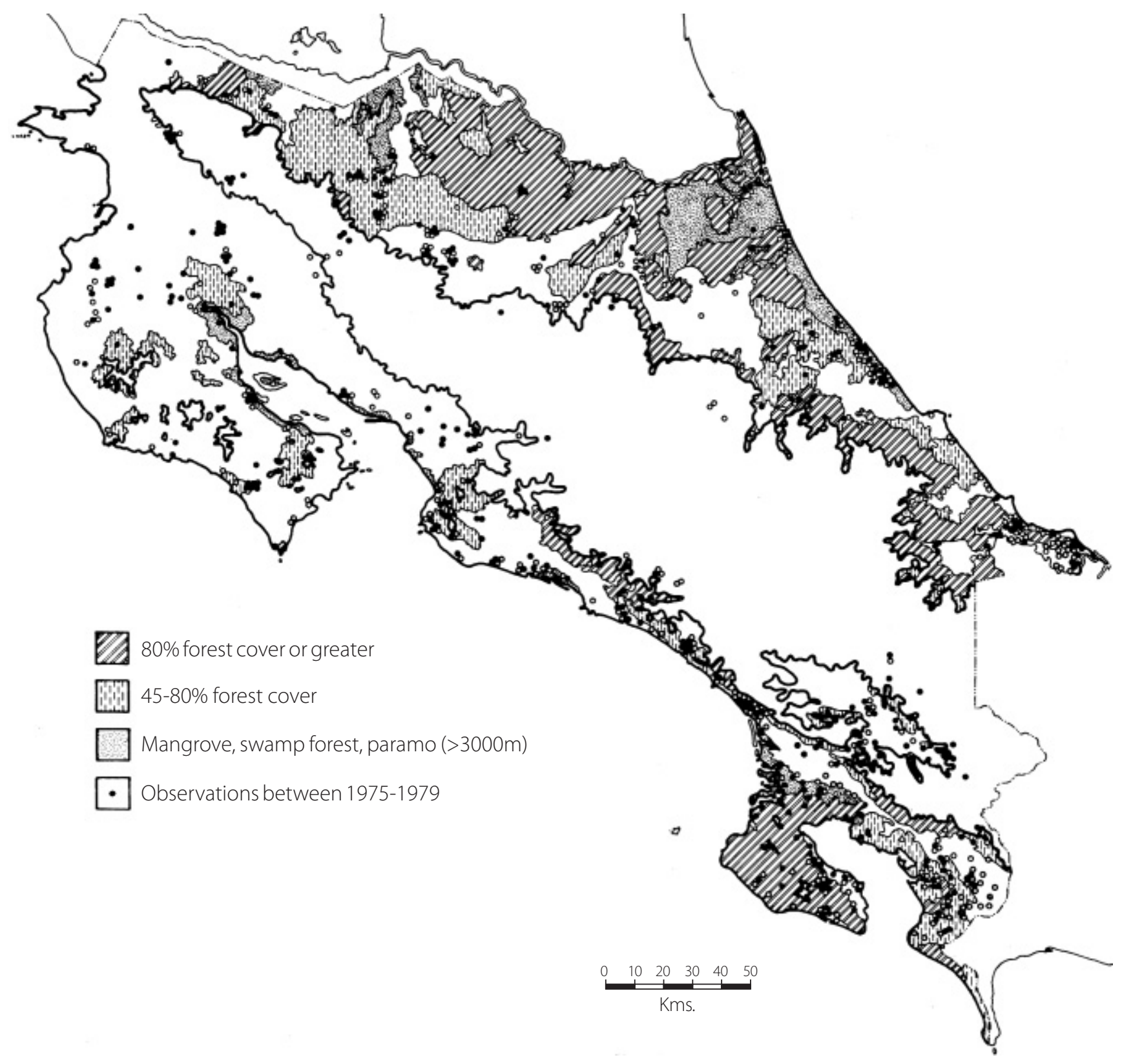

FIG. 31. Forest habitat in Costa Rica (1977) for the species Crocodylus acutus and Caiman crocodilus. 


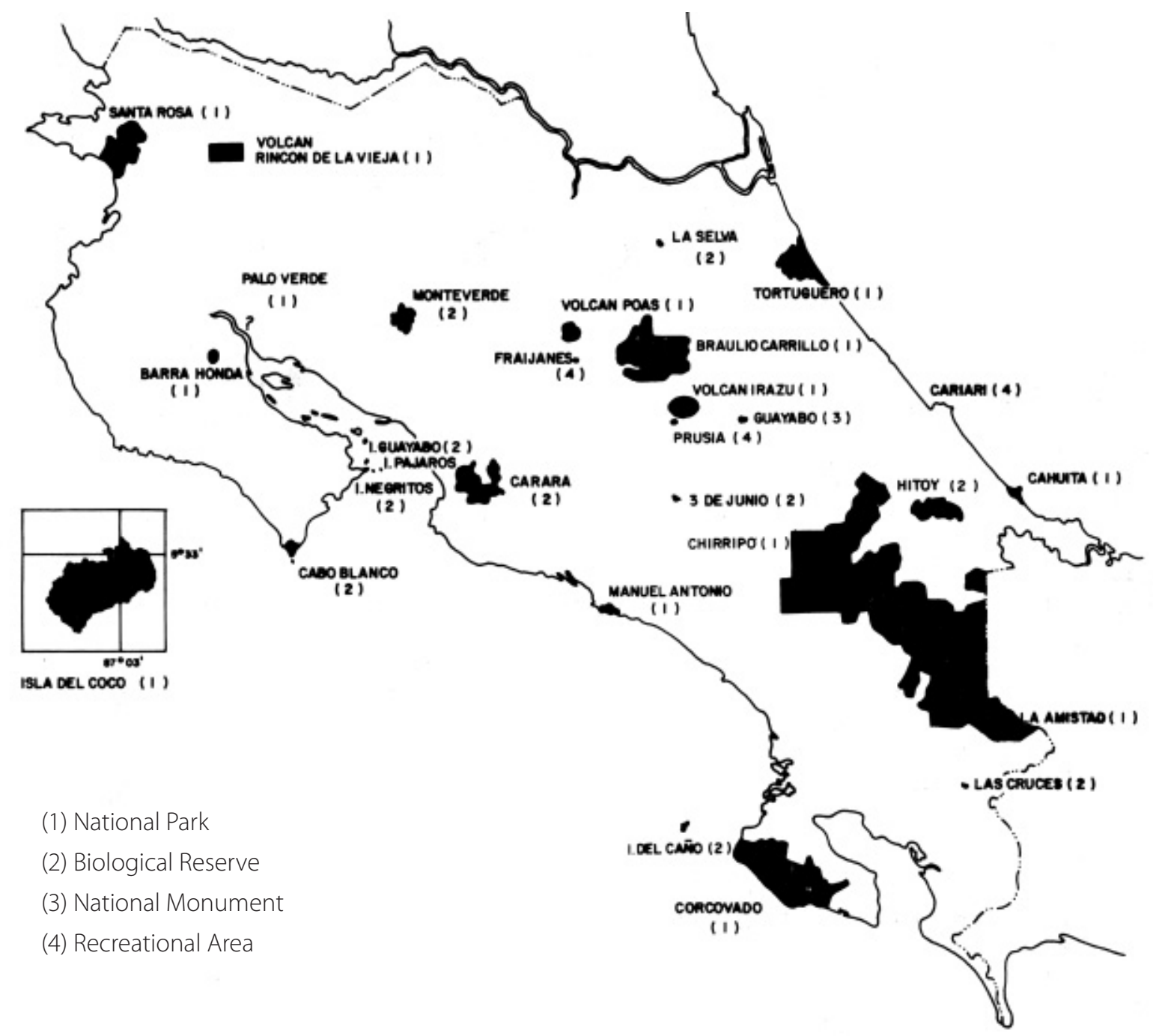

FIG. 32. National Parks, Biological Reserves and National Monuments in Costa Rica. 


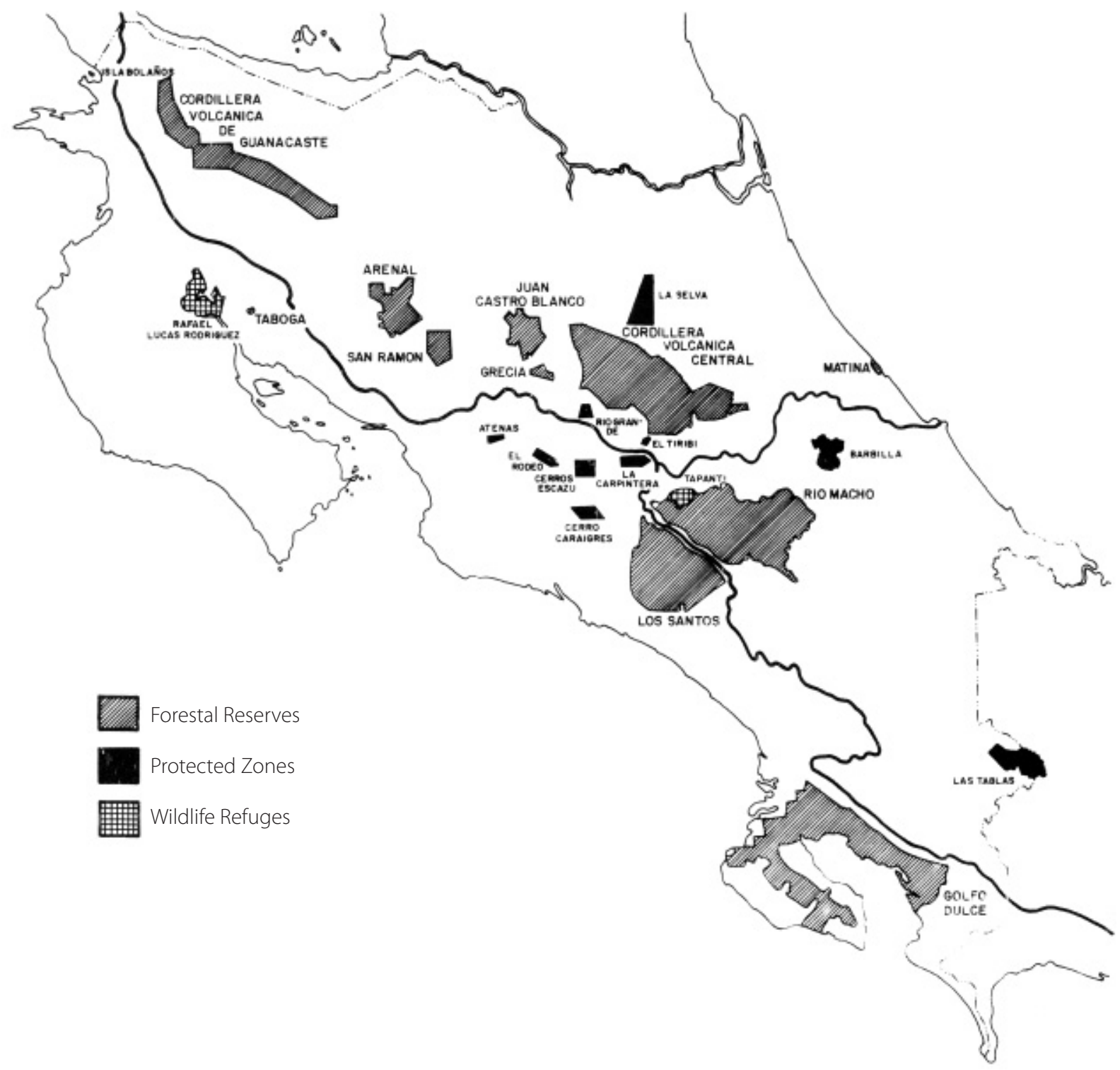

FIG. 33. Forest Reserves, Protected Zones and Wildlife Refuges in Costa Rica. 


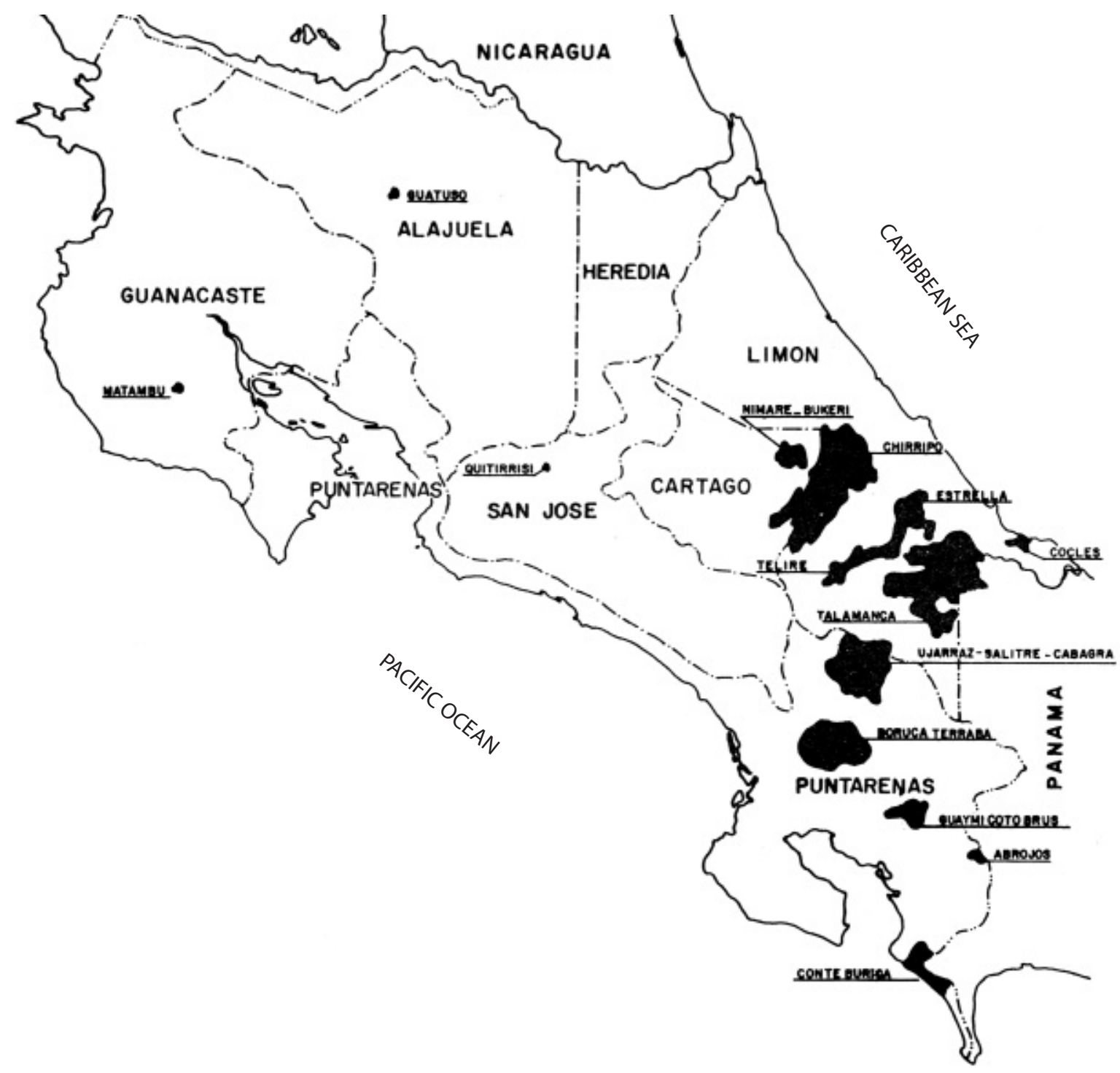

FIG. 34. Indian Reservations in Costa Rica. 
